




DEPARTMENT OF THE INTERIOR

UNITED STATES GEOLOGICAL SURVEY

GEORGE OTIS SMITH, DIRECTOR

\section{BULLETIN 577}

\section{GEOLOGY OF THE PHOSPHATE DEPOSITS NORTHEAST OF GEORGETOWN, IDAHO}

BYY

R. W. RICHARDS AND G. R. MANSFIELD

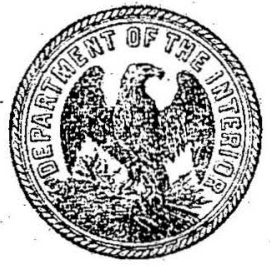

WASHINGTON

GOVERNMENT PRINTING OFFICE

1914 

DEPARTMENT OF THE INTERIOR

UNITED STATES GEOLOGICAL SURVEY

GEORGE OTIS SMTTH, DIRECTOR

BULLETIN 577

\title{
GEOLOGY OF THE PHOSPHATE DEPOSITS NORTHEAST OF GEORGETOWN, IDAHO
}

\author{
BY \\ R. W. RICHARDS AND G. R. MANSFIELD
}

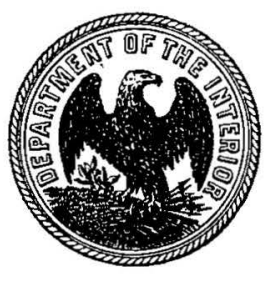

WEASTFFATON

GOVERNMENT PRINTING OFFICE

1914 



\section{CONTENTS.}

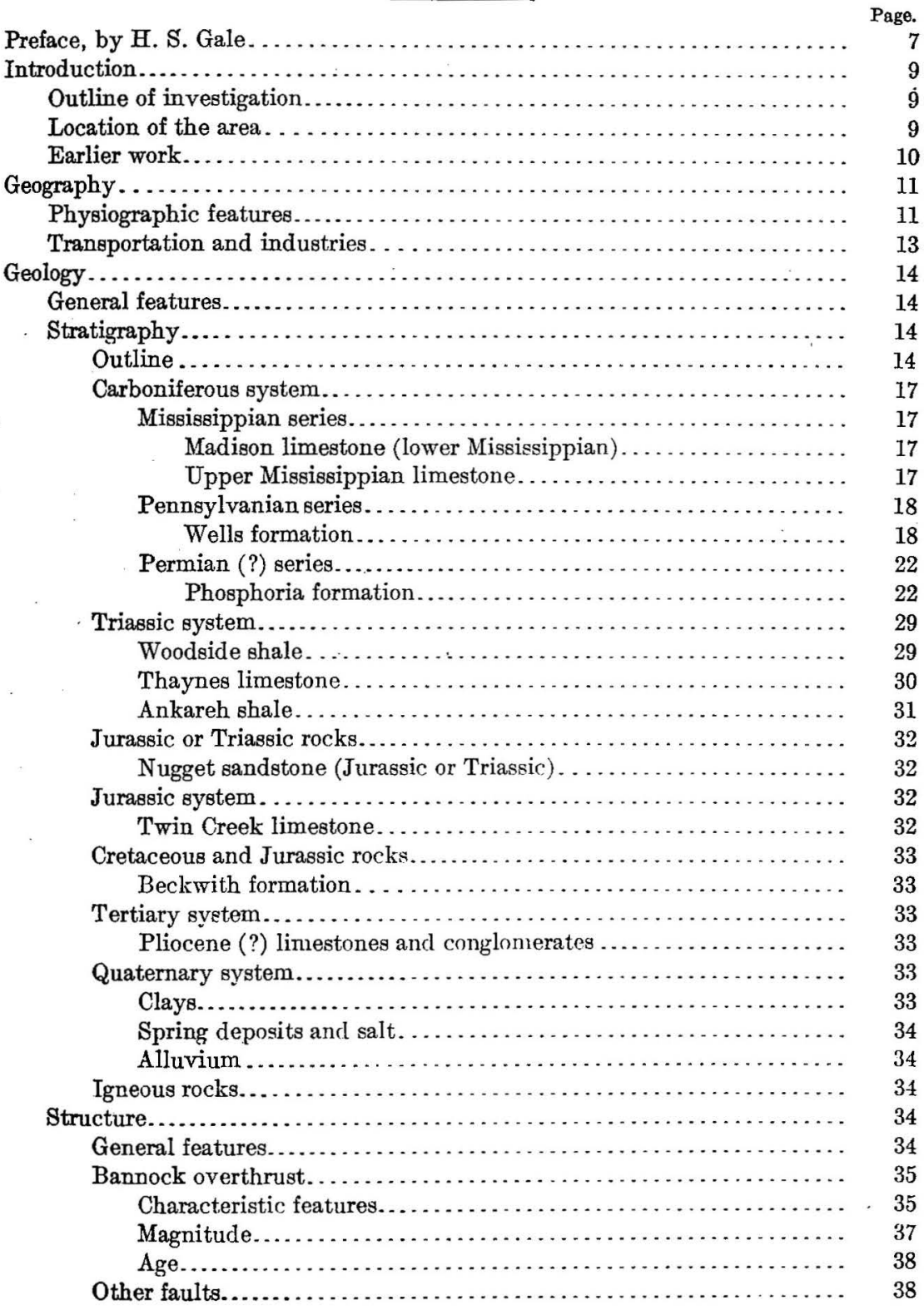


Detailed description of area.......................

Townships examined............................................. 38

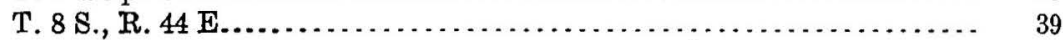

Stratigraphy.................................................... 39

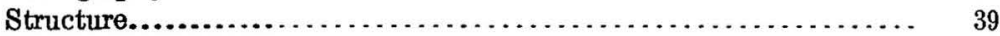

Phosphate deposits..................................... 40

T. 9 S., R. 44 E........................................... 41

Survey.............................................. 41

Stratigraphy................................................ 41

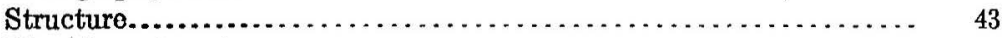

Phosphate deposits................................... 44

T. 10 S., R. 44 E........................................... 46

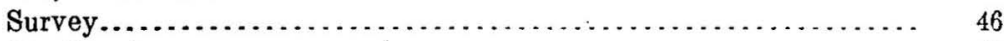

Stratigraphy........................................ 46

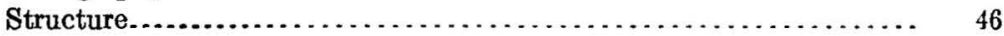

Phosphate deposits................................... 47

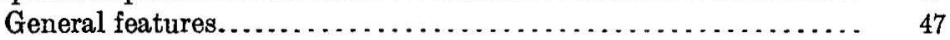

Quality of phosphate rock............................ 47

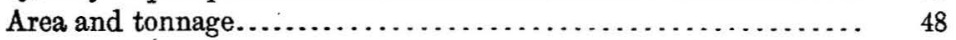

Development......................................... 48

Ownership.............................................. 48

Accessibility......................................... 49

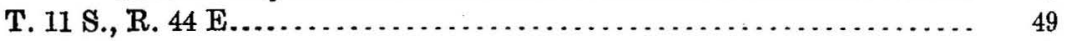

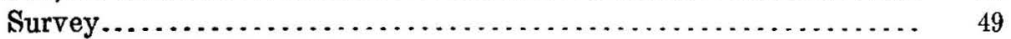

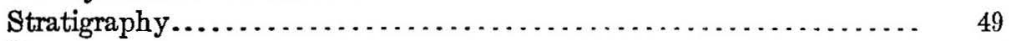

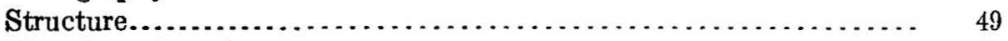

Phosphate deposits....................................... 50

South Canyon district............................ $\quad 50$

General features................................ $\quad 50$

Character of phosphate rock........................ 51

Area and tonnage.................................. 54

Proposed development.......................... 54

Ownership......................................... 55

Meade Peak district................................. 55

Quality of the phosphate rock.................... $\quad 55$

Area and tonnage...................................... 55

Development...................................... 56

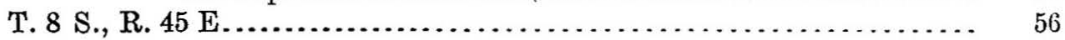

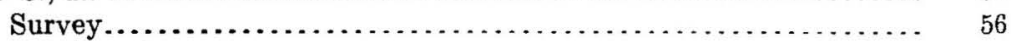

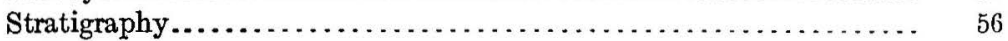

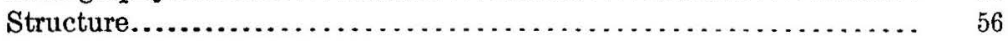

Phosphate deposits.......................................... 57

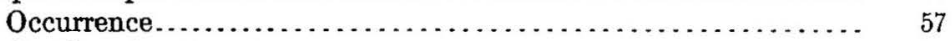

Quality of rock and tonnage.......................... 57

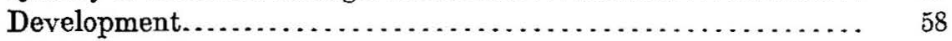

T. 9 S., R. 45 E........................................... 58

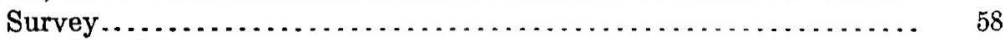

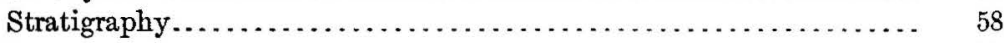

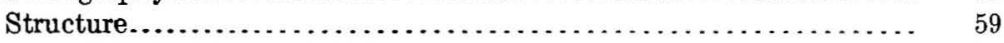

Phosphate deposits.......................................... 59 
Detailed description of area-Continued.

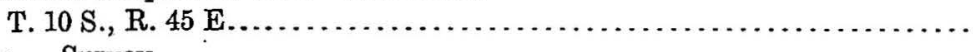

Page.

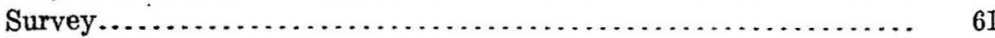

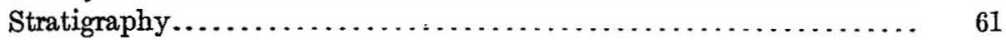

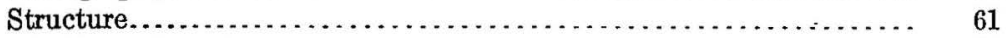

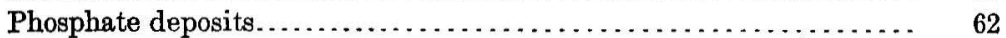

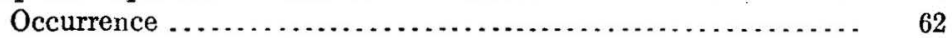

Measured sections and quality of phosphate rock............. 62

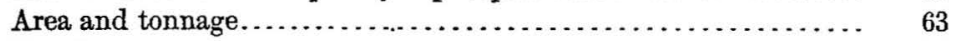

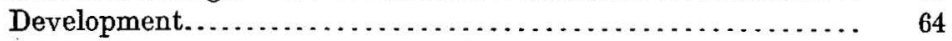

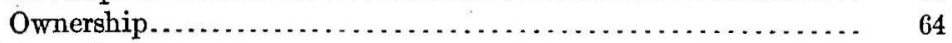

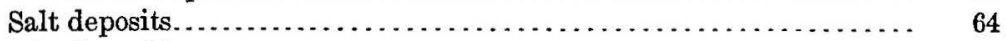

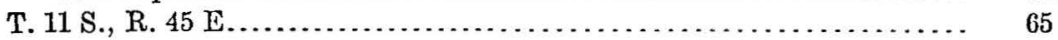

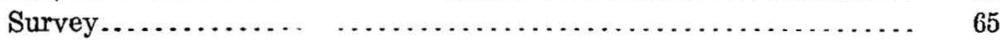

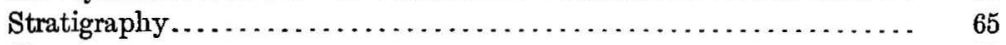

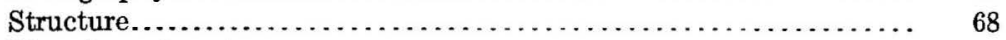

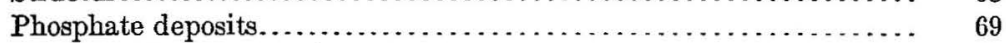

General summary of areas examined............................. 70

Nature and origin of the rock phosphatc......................... 71

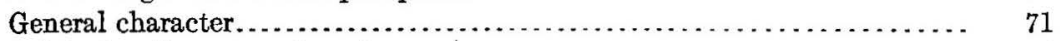

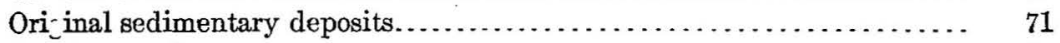

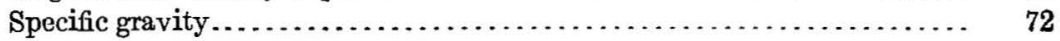

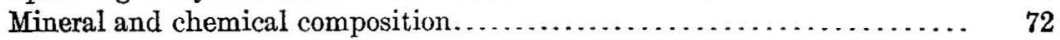

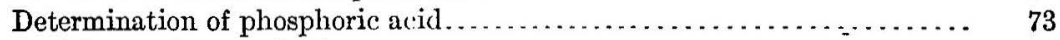

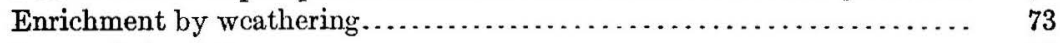

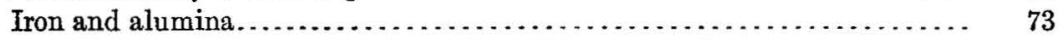




\section{ILLUSTRATIONS.}

Plate I. Meade Peak and South Canyon from the ridge in center of sec. 12,

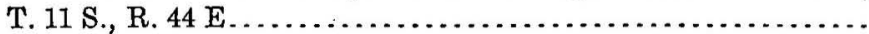

II. $A$, Hill in sec. 16, T. 9 S., R. 44 E.; $B$, Ridge of Rex chert member of the Phosphoria formation extending from sec. 14 through sec. 3 , T. 8 S., R. 44 E.................................... 12

III. Stereogram of part of the region traversed by the Bannock

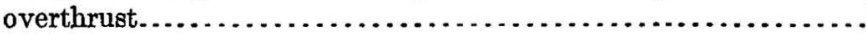

IV. $A$, Panorama from south-pointing spur on hill north of Georgetown Canyon; $B$, Panorama from point near the southeast corner of the area shown in Plate III. ............................ 38

V.. Geologic map and sections, T. 8 S., R. 44 E.................. 40

VI. Geologic map and sections, T. 9 S., R. 44 E................... 42

VII. $A$, Cliffs of Wells formation, west side of Slug Valley, in sec. 18, T. 9 S., R. 44 E.; $B$, Ledges of horizontal beds of the Rex chert member of the Phosphoria formation, sec. 28, T. 9 S., R. $44 \mathrm{E} . .$.

VIII. $A$, Wells formation, sec. 5, T. 10 S., R. 44 E.; $B$, Drag fold in under limestone and phosphate shales in sec. 25 , T. 10 S., R. 44 E..... 45

IX. Geologic map and sections, T. 10 S., R. 44 E................... 46

X. Geologic map and section, T. 11 S., R. 44 E.................... 50

XI. Geologic map and sections, T. 8 S., R. 45 E.................... 56

XII. Geologic map and sections, T. 9 S., R. 45 E................... 58

XIII. Geologic map and sections, T. 10 S., R. 45 E.................. 62

XIV. Geologic map and sections, T. 11 S., R. 45 E................. 68

Froure 1. Map showing phosphate reserves in Idaho on July 1, 1912....... 10

2. Map showing the relative position of the townships in the phosphate area and their general geologic features.............. 15 


\section{PREFACE.}

By Hoyt S. Gale.

The original discovery of the western phosphate fields is claimed by Albert Richter, of Salt Lake City, ${ }^{1}$ who, according to his own report, first recognized the true character of the deposits somewhere in the vicinity of La Plata, Cache County, Utah, in 1889, and traced the deposits as far as Bear Lake, locating a number of claims and excavating diseovery pits on them. Richter states that in 1901 he laid the matter before several of the larger fertilizer manufacturers in the Central States, who made analyses of the samples that proved them to contain high-grade phosphate, but evidently these firms did not at that time deem it worth while to investigate the deposits further, probably because of their remoteness from the market.

Later, according to C. C. Jones, ${ }^{2}$ the deposits were independently recognized by R. A. Pidcock, who in the summer of 1897 found some old prospects, presumably located for gold, in a soft black formation on Twelvemile Creek, a branch of Woodruff Creek in Rich County, Utah, and obtained an analysis of the rock which showed it to be phosphate. In May, 1903, according to his own statement, Mr. Jones examined the deposits on Woodruff Creek; and after studying them in the field he succeeded in tracing their outcrops in many places throughout southeastern Idaho, southwestern Wyoming, and northeastern Utah. The deposits had previously attracted the attention of many prospectors, who had made locations on them for their possible content of the precious metals and because of the superficial resemblance of the outcrop to coal blossom. Mr. Jones, however, became a pioneer in the first actual development of the field for its phosphate, and to him much credit is due for the systematic, scientific way in which his field investigations were prosecuted. His papers cited above give an account of his methods and fields of work.

Commercial development of the fields has undoubtedly been retarded by their situation, remote from fertilizer markets in which such material might be utilized, which necessitates rail transportation at high cost. Without much question, development has also been

\footnotetext{
1 Western phosphate discovery: Mines and Methods, vol. 2, No. 9, p. 207, 1911.

Phosphate rock in Utah, Idaho, and Wyoming: Eng. and Min. Jour., vol. 83, pp. 953-955, 1907; The discovery and opening of a new phosphate field in the United States: Am. Inst. Min. Eng. Bull. 82, pp. 2411-2435, October, 1913.
} 
more or less impeded by legal difficulties that have arisen in regard to the method of location and the titles of these lands. Methods of acquiring private ownership of this type of mineral deposit had not previously been specifically provided in the public-land laws. However, when the more detailed work of the Geological Survey was first undertaken in these fields in 1909, many of the properties more readily accessible to existing railroad lines had already passed into private control, although a vastly greater area still remained, literally unprospected, as a part of the public domain.

The first lands withdrawn in these phosphate fields comprised an area of about 7,000 square miles in Idaho, Utah, and Wyoming. This withdrawal was made by direction of the Secretary of the Interior under date of December 9, 1908. Thus this action preceded specific land examinations for the purpose of accurately defining the field. The area withdrawn was outlined by the aid of an interpretation of the geology of the region as shown on the Hayden Survey map made in 1877. This interpretation was made in the light of more recent knowledge of the geologic relations of the deposits.

The United States Geological Survey's investigations in the western phosphate fields began in 1906 . Since 1909 detailed study and classification of phosphate and nonphosphate lands has been made a part of each summer's field work. The results of this work have been published in the form of progress reports, and references to these reports are given in this paper, which forms one of the series and which is the first to appear as a separate bulletin.

The type of geologic survey represented in this work is a development of the constantly increasing requirement for detail. The delineation of phosphate outcrops in areas beyond the properties that have been located and the estimation of the depth, tonnage, and quality of the different beds furnish part of the data required for land classification. This work has been done by accurate instrumental methods, and the mapping has in large part been performed with a degree of refinement which it is unfortunately not possible to reproduce on the small scale of the plates in this bulletin.

Special acknowledgment is due to the authors for their important contribution to the knowledge of the structural geology of this region, through the recognition and the excellent exposition they have given of the important fault which has been named the Bannock overthrust. A paper on this fault has already been printed elsewhere. ${ }^{1}$

1 Richards, R. W., and Mansfield, G. R., The Bannock overthrust, a major fault in southeastern Idaho and northeastern Utah: Jour. Geology, vol. 20, pp. 681-709, 1912. 


\title{
GEOLOGY OF THE PHOSPHATE DEPOSITS NORTHEAST OF GEORGETOWN, IDAHO.
}

\author{
By R. W. Riohards and G. R. Mansfield.
}

\section{INTRODUCTION.}

\section{OUTLINE OF INVESTIGATION.}

The geologic examination of the western phosphate fields for the United States Geological Survey was continued in 1911 by the authors of this bulletin in Idaho and by Eliot Blackwelder in Wyoming.

The area studied includes a portion of the lands comprising the phosphate reserve created by the withdrawals of December, 1908, and December, 1909, by the Secretary of the Interior, which were ratified, confirmed, and continued by the President under the act of June 25, 1910.

This paper is a progress report of the detailed geologic work for the year in southeastern Idaho. The authors were assisted in the field by E. L. Troxell and E. C. Ragar. The chairman of the landclassification board, W. C. Mendenhall, made a brief inspection of the field methods employed by the party and contributed useful suggestions on several of the problems. E. H. Finch was detailed to the party for the month of August. G. H. Girty, paleontologist, was with the party for three weeks in September and made further study of the stratigraphy of the Carboniferous and Triassic portions of the section. F. B. Van Horn and A. R. Schultz made a short visit to the party during the later part of September.

After the close of the detailed work for the year the senior author and Mr. Schultz spent two weeks in a reconnaissance of an area lying north of the townships described in this report and south of Snake River. A report embodying the results of this reconnaissance has been published in Bulletin 530 .

\section{LOCATION OF THE AREA.}

The accompanying map of the phosphate reserves in Idaho (fig. 1) shows the area examined in 1911 and its relation to the areas surveyed in the preceding years and described in Bulletins 430 and 470. The area discussed in this report comprises portions of Bear Lake 


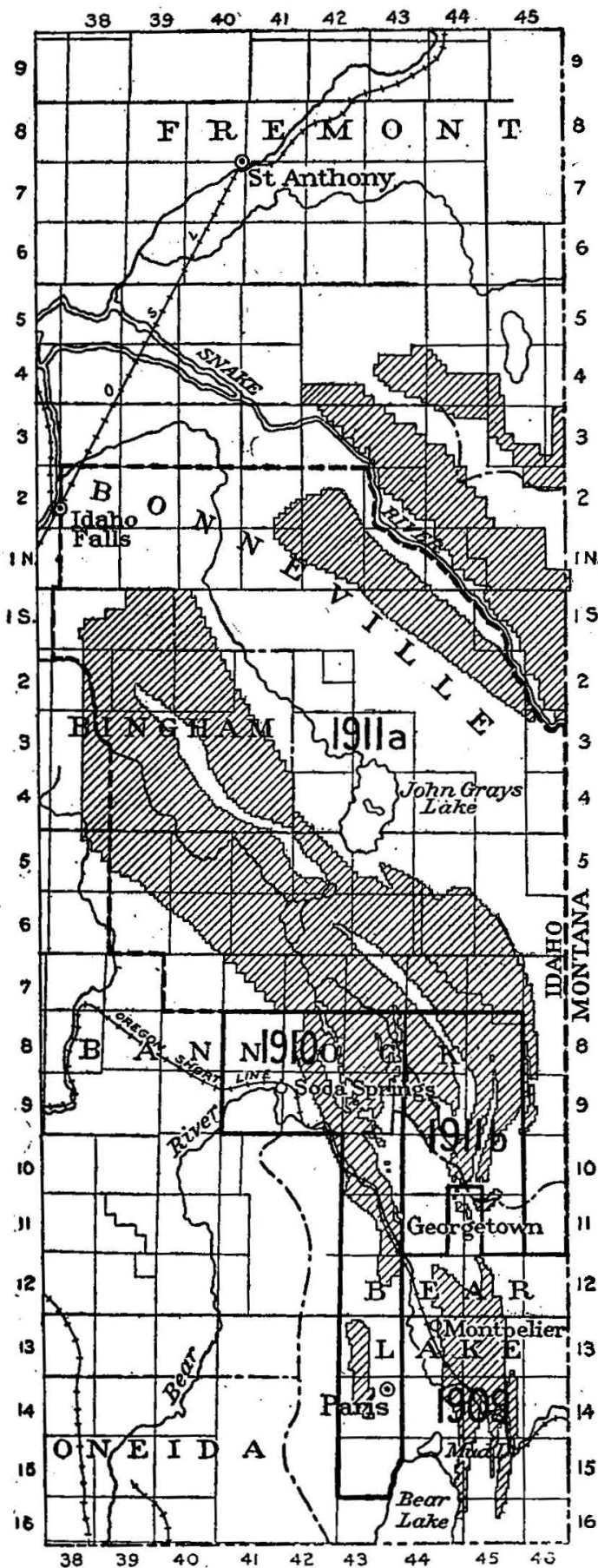

FIGURE 1.-Map showing phosphate reserves in Idaho on July 1, 1912. Shaded areas indicate phosphate lands. The areas surveyed in 1909-1911, inclusive, are indicated (a, reconnaissance; $b$, detailed survey). and Bannock counties in southeastern Idaho, and includes the phosphate deposits in Georgetown Canyon, which were briefly described in the report for $1909 .{ }^{1}$

\section{EARLIFR WORK.}

The earliest report on the geology of the region is that of the reconnaissance of 1877 by A. C. Peale ${ }^{2}$ of the Hayden Survey. If the rapidity with which this work was done is considered, it is an excellent summary of the broader stratigraphic and structural features.

In 1907 Weeks and Ferrier ${ }^{3}$ published a general account of the western phosphate fields with brief descriptions of several localities, including the Georgetown Canyon district (T. 10 S., R. 44 E.).

In 1910 H. S. Gale ${ }^{4}$ and the senior author of this bulletin pub-

1 Gale, H. S., and Richards, R. W., Preliminary report on the phosphate deposits in southeastern Idaho and adjacent parts of Wyoming and Utah: U. S. Geol. Survey Bull. 430 , pp. 457-535, 1910.

2 Peale, A. C., U. S. Geol. and Geog. Survey Terr. Eleventh Ann. Rept., pp. 511-644, 1879.

3 Weeks, F. B., and Ferrier, W.F., Phosphate deposits in western United States: U. S. Geol. Survey Bull. 315, pp. 449-462, 1907.

4 Gale, H. S., and Richards, R. W., Preliminary report on the phosphate deposits in southeastern Idaho and adjacent parts of Wyoming and Utah: U. S. Geol. Survey Bull. 430, pp. $483-488,1910$. 


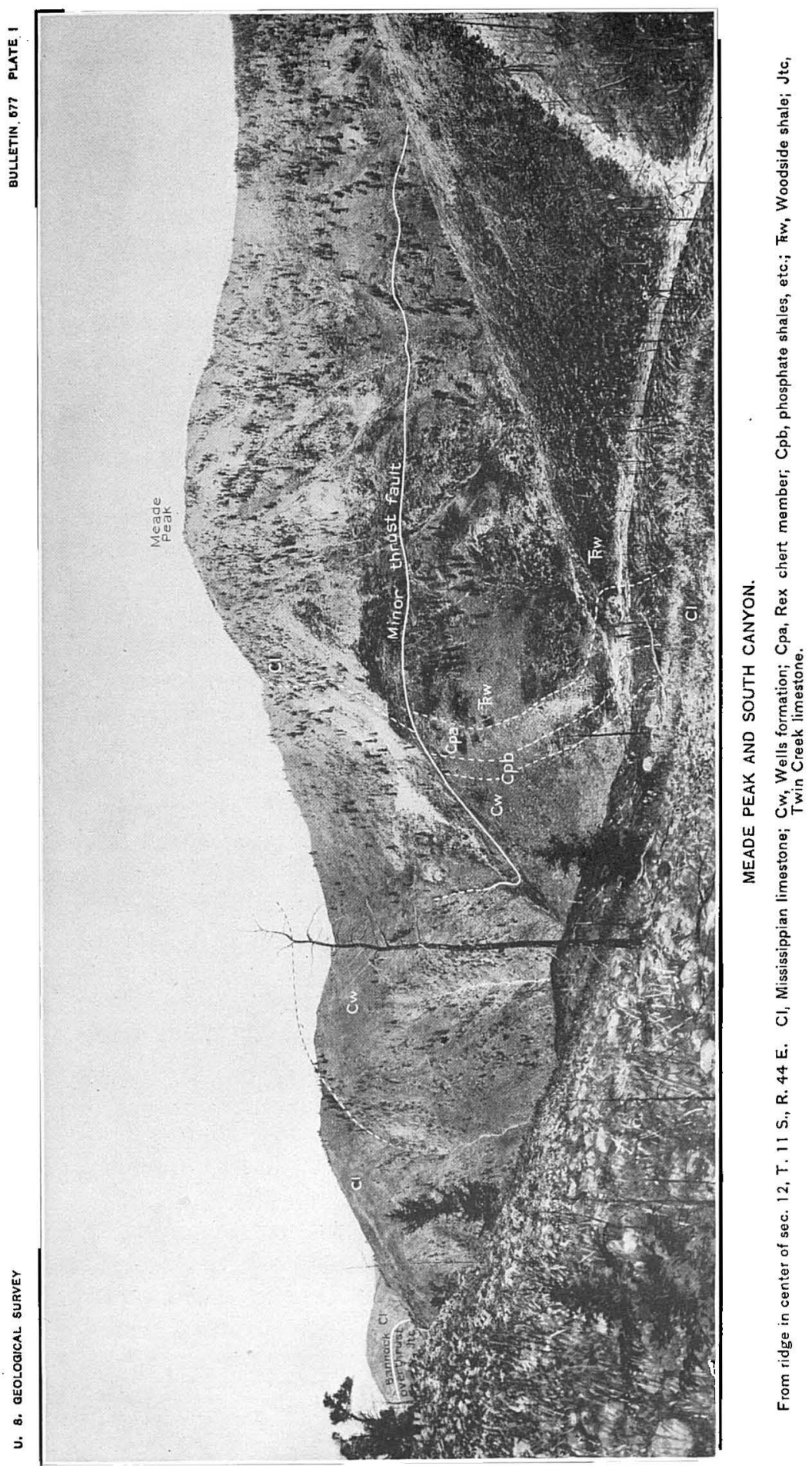



lished a more detailed reconnaissance of the Georgetown Canyon district, in which the extent and quality of the phosphate deposits of the area was first presented.

In the same year C. L. Breger ${ }^{1}$ described the geology of the portion of the area that includes Crow Creek and discussed the origin of the salt deposits of the vicinity.

In 1911 the writers ${ }^{2}$ published a preliminary report of detailed geologic work in areas adjacent to the region described in the present report and in the paper by Mr. Gale and the senior author.

\section{GEOGRAPHY.}

\section{PHYSIOGRAPHTC FEATURES.}

The area examined in detail in 1911 comprises eight townships lying in the two ranges immediately east of the area surveyed in 1910 and including Tps. 8 to $11 \mathrm{~S}$., Rs. 44 and $45 \mathrm{E}$. of the Boise meridian. The geographic features of the region therefore form the eastward continuation of those described in the report of the work done in $19100^{8}$

The general topography of the area is marked by a series of curving ridges, whose trend varies from a little east of north in the southern part of the area to northwest in the northern part. Between the ridges are valleys that in the southern part are relatively narrow and deeply cut but in the central and northern parts are broadly opened basins.

The most pronounced topographic feature of the region is the series of ridges that passes northward nearly through the center and comprises portions of the Preuss Range, Snowdrift Mountain, and Dry Ridge. Meade Peak (Pls. I and IV, A), in the SW. $\frac{1}{1}$ NW. $\frac{1}{4}$ sec. 6, T. 11 S., R. $45 \mathrm{E}$., which has an elevation of 9,953 feet, is the highest point of the region. Snowdrift Mountain, a ridge 4 or 5 miles long, has an elevation of 9,000 to 9,700 feet, and Dry Ridge maintains an elevation of 8,500 to nearly 9,000 feet for a distance of 10 miles or more. To the east and west the ridges are broader and more interrupted.

The lowest elevation, about 5,950 feet, is found in the southwest corner of T. 11 S., R. $44 \mathrm{E}$. The maximum relief is therefore about 4,000 feet. The larger canyons are cut from 1,000 to 2,500 feet or more below their adjacent ridges.

The area lies within two great drainage basins. The southwest part is drained by branches of Bear River, one of the main feeders of Great Salt Lake. The greater part, however, is contributory to the

\footnotetext{
1 Breger, C. L., The salt resources of the Idaho-Wyoming border, with notes on the geology: U. S. Geol. Survey Bull. 430, pp. 555-569, 1910.

2Rlchards, R. W., and Mansfield, G. R., Preliminary report on a portion of the Idaho phosphate reserve:

U. S. Geol. Survey Bull. 470, pp. 371-439, 1911.

Idem, Pp. 372-874.
} 
Snake-Columbia system and drains into the Pacific Ocean. The divide, which thus constitutes a part of the Great Basin and Pacific divide, lies along the boundary between Bear Lake and Bannock counties and passes westward south of Crow Creek in T. 11 S., R. 45 E., northward along Snowdrift Mountain in T. 10 S., R. 45 E., around the head of Georgetown Canyon, and westward around the head of Slug Creek in T. 10 S., R. 44 E.

The topography shows a very close adjustment to structure. The region is crossed by a series of narrow folds that pitch gently northward and have the same general trend as the ridges. The great longitudinal valleys are strike or subsequent valleys, eroded along the outcrop of the softer or weaker members of the strata exposed. Dry Valley, the largest depression within the area, is excavated on the west flank of an anticline. Its southern part is drained westward by transverse streams into Slug Valley. The northern part drains northward into Blackfoot River. The divide lies in the broad flat floor of the valley.

There are numerous small strike valleys, and one is sufficiently large and well developed to merit special comment. This valley crosses the northeast part of T. 8 S., R. 44 E., and causes Dry Ridge to fork into a main ridge and a well-marked subordinate flanking ridge on the west (Pl. II, $B$ ). This valley lies along the contact between the heavy cherts of the Rex chert member of the Phosphoris formation on the west and the sandy and shaly limestones of the Woodside shale on the east. The Rex chert forms a remarkable dip slope along the west side of this valley.

The topography gives evidence of three well-defined cycles of erosion. The hill and ridge tops have developed more or less even sky lines or gentle slopes, indicating an advanced stage of erosion These older surfaces are cut by the present sharp-featured canyons, most of which are young. An intermediate level at an elevation of about 7,500 to 7,750 feet is well marked in many places, particularly in Georgetown Canyon in T. 10 S., R. 44 E., where rock terraces extend along both sides of the canyon about 2,000 feet below the bordering ridges. These terraces appear to indicate an intermediate, maturely developed cycle of erosion, for they occur not only where rocks of different character and resistance form the ridge and terrace, as in Georgetown Canyon, but also where rocks of the same general character and resistance form both ridge and terrace, as along the west side of Dry Ridge in T. 9 S., R. 45 E. These intermediate terraces seem to lack uniform development, probably because of the varying resistance and structure of the rocks involved.

The basins of the region are important topographically and are valuable for grazing and agricultural land. - Some are apparently of structural origin, like the beautiful basin in the southwest corner of 


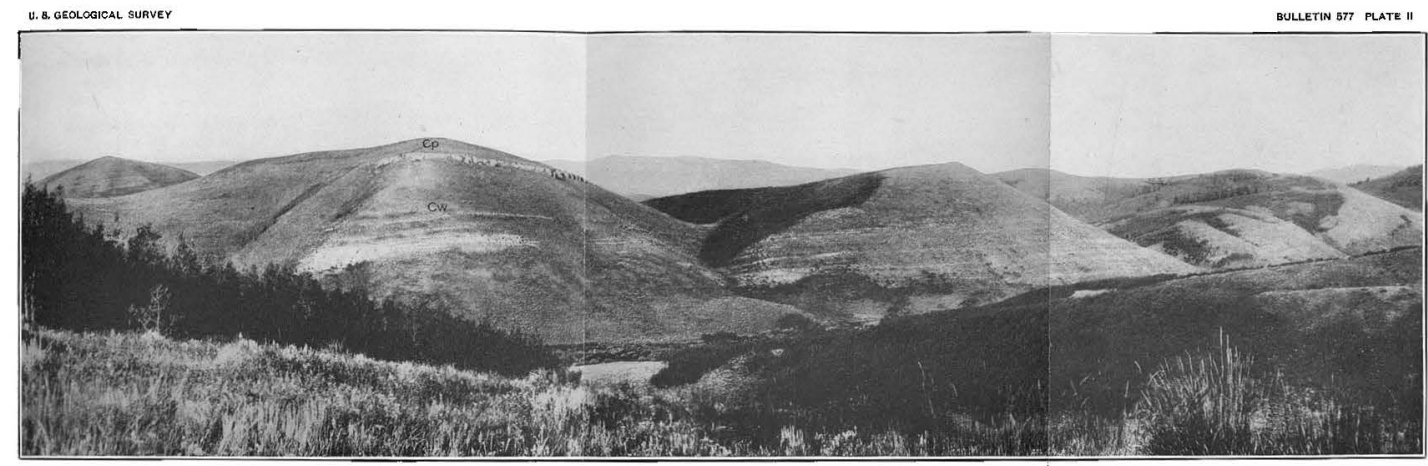

A. HILL IN SEC. 16, T. 9 S., R. 44 E.

Showing succession from lower part of Welis formation $\left(\mathrm{CW}_{W}\right)$ to upper part of Phosphoria formation $\left(\mathrm{C}_{\mathrm{p}}\right)$

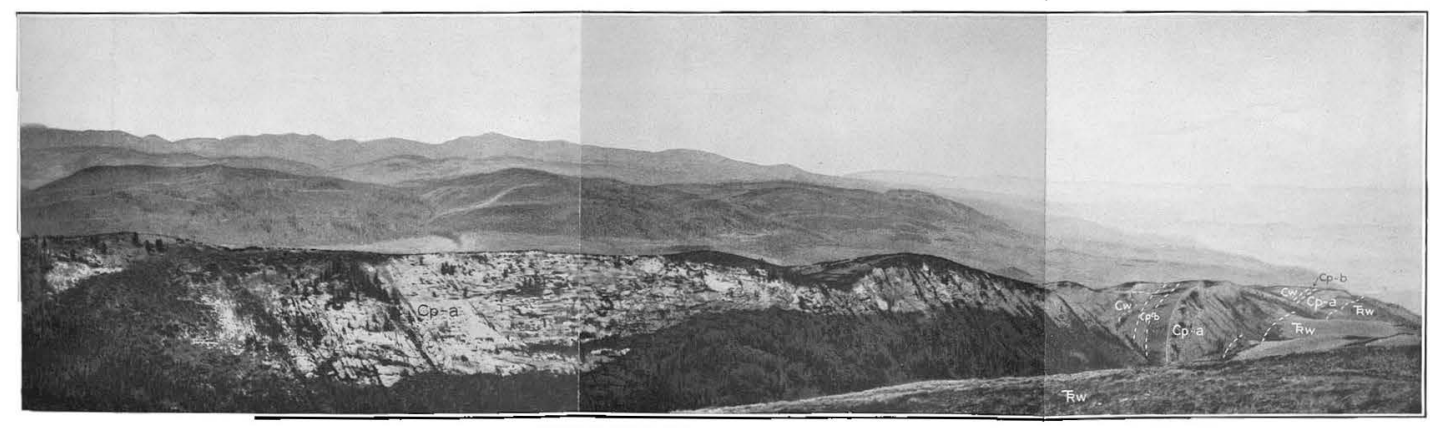

B. RIDGE EXTENDING FROM SEC, 14 THROUGH SEC. 3, T. 8 S., R. 44 E

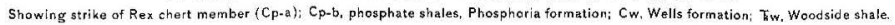



T. 9 S., R. 44 E. Others, like Slug Valley and Dry Valley, are eroded along the strike of upturned beds. In Slug Valley the formation of the basin may also have been influenced by the faulting. In other portions of the area, as in secs. 10 and 22, T. 9 S., R. 45 E., basins have been developed at the intersection of longitudinal and transverse valleys, which now form excellent grazing meadows. The slopes of the floors of these basins are so gentle and the drainage is so poor that alluvial deposits have accumulated and have partly buried some of the lower rock hills, which now rise like islands above the level of the alluvium.

Alluvial fans are formed along the borders of the larger basins, particularly along the east side of Dry Valley, a fine example being found in sec. 9, T. 8 S., R. 44 E. These fans are now somewhat dissected.

Along the top of Snowdrift Mountain in T. 10 S., R. 45 E., a series of interesting basins has been formed, probably by the combined action of solution and nivation. ${ }^{1}$ The exterior walls of the basins rise about 30 to 50 feet above the basin floors and, were it not for the gaps here and there, which allow views of the adjacent lower country, the traveler passing through these basins would hardly realize that he was on the top of a high mountain. The basins are excavated in limestones that have sharp anticlinal structure. Small sink holes also occur in places along the top of the ridge.

\section{TRANSPORTATION AND INDUSTRIES.}

The region surveyed is touched by the Oregon Short Line Railroad at three points in Idaho, namely, Georgetown, Montpelier, and Soda Springs. Georgetown, however, is the only village strictly within the area here described. The location of the other two towns mentioned is shown on the general map (fig. 1, p. 10).

Wagon roads to each of these three towns constitute the principal lines of travel in the area. The Montpelier-Afton (Wyoming) stage road is kept open throughout the year, but the roads from Georgetown and Soda Springs, although possibly better for summer travel, are generally rendered impassable by the heavy snowfall of winter.

About seven-eighths of the area lies within the Caribou National Forest. However, a large portion of that area is not idle, for both grazing and lumbering under a system of permits are in operation. The sparsely timbered areas are no longer overstocked, as they were prior to the establishment of the national forest, and the well-timbered areas are utilized with a view to conservation. The attitude of the inhabitants of the region toward the national forest is well shown

1 Matthes, F. E., U. S. Geol. Survey Twenty-first Ann. Rept., pt. 2, pp. 179-185, 1800. 
by the report that they have petitioned for an extension of the forest, to include the unreserved portion of the Montpelier Creek basin.

Except in the vicinity of Georgetown, Crow Creek, and lower Slug Creek, the ranches are occupied only during the summer months, and the inhabitants are occupied mainly with dairying and sheep grazing.

The continued growth of the settlements centering about Afton, Wyo., in the Star Valley, together with the economic value of the phosphate, saline, and other deposits of the region, will eventually lead to further railroad construction. Several preliminary location surveys are reported to have been made, but little is known as to which is the most desirable or most likely to be utilized.

\section{GEOLOGY.}

\section{GENERAL FEATURES.}

The greater part of the area, including that which contains the valuable phosphate deposits, is underlain mainly by stratified rocks ranging from early Carboniferous to Lower Triassic age. Besides these rocks small areas of Tertiary and Quaternary rocks, including basalt, are present and locally conceal the older formations.

In the southern and eastern part of the area the higher Triassic, Jurassic, and basal Cretaceous rocks outcrop. Their presence in apparently undisturbed sequence indicates that the Permian (8) phosphate deposits lie too deep for recovery.

All the rocks of the area, except those of late Tertiary and Quaternary time, have been so folded that the areal distribution of any formation is determined mainly by the structure of the rocks.

Major and minor faulting in addition to the folding complicates the distribution of the several formations, so that certain local areas of the Thaynes limestone and Woodside shale are not underlain, as they are in most places, by the Permian (?) phosphate, and conversely the strata are in places overturned so that rocks older than the phosphate actually overlie it. This complexity of the structure justifies a rather extended review of the stratigraphy and the structure of the region.

\section{STRATIGRAPHY.}

OUTLINE.

The general characters of the several geologic formations outcropping in the area examined are given in the table (p. 16), and further details concerning them are set forth in the following pages.

Figure 2 shows the general geologic relations of the region discussed in this report. 


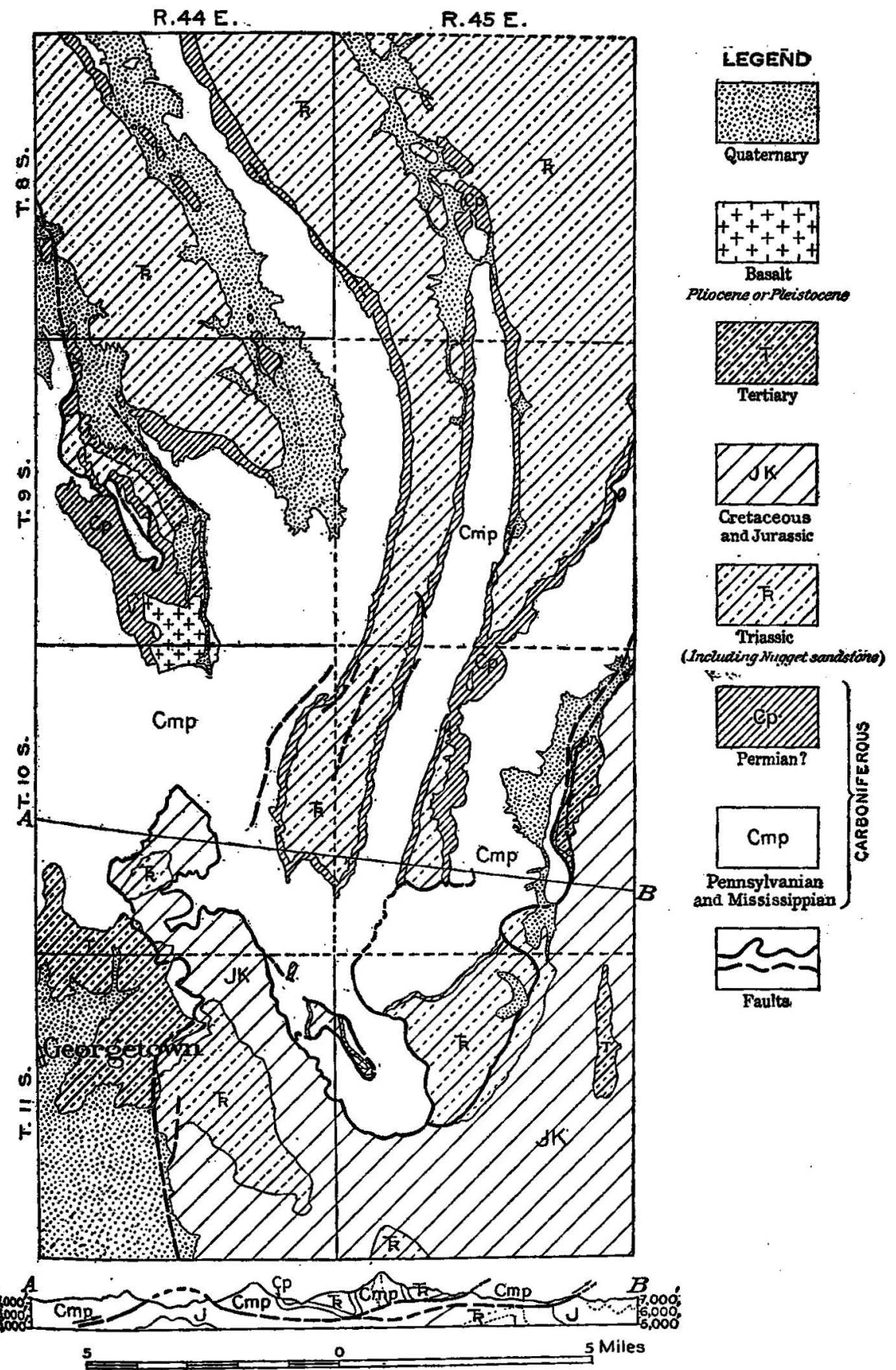

herese 2,-Map showing the relative position of the townships in the phosphate area and their general geologie features. Geologic section at bottom. 
General section of phosphate area in southeastern Idaho.

\begin{tabular}{|c|c|c|c|c|}
\hline System. & Series. & Formation. & $\begin{array}{c}\text { Thick- } \\
\text { ness } \\
\text { (feet). }\end{array} \mid$ & General character. \\
\hline Quaternary. & & & (a) & $\begin{array}{l}\text { Alluvium, travertine, clays, and } \\
\text { basalt flows. }\end{array}$ \\
\hline Tertiary. & $\begin{array}{l}\text { Pliocene } \\
(?) .\end{array}$ & \multirow{2}{*}{$\begin{array}{l}\text { Unconformity. } \\
\text { Beckwith formation. }\end{array}$} & (a) & $\begin{array}{l}\text { White marls, marly limestones, } \\
\text { calcareous conglomerates; dens, } \\
\text { nearly lithographic limestones } \\
\text { near Soda Springs; pea-green } \\
\text { grits. }\end{array}$ \\
\hline Cretaceous and Jurassic. & & & $4,650 \pm$ & $\begin{array}{l}\text { Red shale and sandstone for } 1,200 \\
\text { feet, overlain by } 250-600 \text { feet of } \\
\text { greanish-gray sandstone, which's } \\
\text { overlain by conglomerate suc- } \\
\text { ceeded by limestone. }\end{array}$ \\
\hline Upper Jurassic. & & Twin Creek limestone. & $3,500 \pm$ & Grayish-white shaly limestone. \\
\hline Jurassic or Triassic. & & Nugget sandstone. & 1,900 & $\begin{array}{l}\text { Massive red sandstone, with white } \\
\text { conglomeratic sandstone at base } \\
\text { and locally white sandstone at } \\
\text { top. In places silicified to a } \\
\text { quartzite. }\end{array}$ \\
\hline \multirow{3}{*}{ Lower Triassic. } & & Ankareh shale. & $b 670$ & $\begin{array}{l}\text { Essentially red shale and mottled } \\
\text { red and greenish clay and shales, } \\
\text { with some sandstone and some } \\
\text { limestone. }\end{array}$ \\
\hline & & Thaynes limestone. & $2,000 \pm$ & $\begin{array}{l}\text { Main body of the formation dark } \\
\text { blue limestone, in many places } \\
\text { fossiliferous, weathering to a } \\
\text { brown muddy color, also includ- } \\
\text { ing sandy and calcareous shale. }\end{array}$ \\
\hline & & Woodside shale. & $\begin{array}{c}c 1,000- \\
1,500\end{array}$ & $\begin{array}{l}\text { Thin-bedded calcareous shales, } \\
\text { with intercalated muddy lime- } \\
\text { stones; heavy limestone beds at } \\
\text { top. }\end{array}$ \\
\hline \multirow{4}{*}{ Carboniferous. } & $\begin{array}{c}\text { Permian } \\
(?)\end{array}$ & \multirow[t]{2}{*}{$\begin{array}{l}\text { Phosphoria formation. } \\
\text { Unconformity in places. }\end{array}$} & $315-730$ & $\begin{array}{l}\text { (a) Rexchert member at top, 240-550 } \\
\text { feet. One or more massive } \\
\text { strata of cherty limestone of } \\
\text { chert, prominent as a ledge } \\
\text { maker, grading in part to a pur- } \\
\text { plish cherty or linty shale. } \\
\text { (b) Rock phosphate, phosphatio } \\
\text { shale, sandstone, and minot } \\
\text { limestone bands. }\end{array}$ \\
\hline & $\begin{array}{c}\text { Pennsyl- } \\
\text { vanian. }\end{array}$ & & 2,400 & $\begin{array}{l}\text { Massive white calcareous sand- } \\
\text { stone, weathering with project } \\
\text { ing fossil fragments, generally } \\
\text { with bluish chert bands and in } \\
\text { some localities with black chert } \\
\text { in rounded nodules in the lower } \\
\text { portion. } \\
\text { white sandstone and quartzite, } \\
\text { calcareous sandstones, and light- } \\
\text { colored limestones, with variable } \\
\text { amounts of interbedded quartz- } \\
\text { ites. Light-colored cherty lime- } \\
\text { stone with interbedded sand- } \\
\text { stones. }\end{array}$ \\
\hline & $\begin{array}{l}\text { Upper } \\
\text { Missis- } \\
\text { s i p- } \\
\text { pian. }\end{array}$ & : & $1,130+$ & $\begin{array}{l}\text { Bluish-gray thick-bedded lime- } \\
\text { stones with spherical nodules of } \\
\text { black chert; gray sandy lime } \\
\text { stone streaked with calcite and } \\
\text { specked with siderite; locally } \\
\text { marked with fossil corals, crinoid } \\
\text { stems, and brachiopods. }\end{array}$ \\
\hline & $\begin{array}{l}\text { Low er } \\
\text { Missis- } \\
\text { s i p - } \\
\text { pian. }\end{array}$ & Madison limestone. & $1,000 \pm$ & $\begin{array}{l}\text { Thick massive blue to gray lime } \\
\text { stone, generally making high } \\
\text { mountainous country where } \\
\text { brought to the surface in mass; } \\
\text { thinner bedded than overlying } \\
\text { limestone. }\end{array}$ \\
\hline
\end{tabular}




\section{CARBONIFEROUS SYSTEM.}

MISSISSIPPIAN SERIES.

MADISON LMAESTONE (LOWER MISSISSIPPIAN).

The basal Carboniferous sediments of the area are dark bluish-gray, relatively thin-bedded limestones, which resist erosion and form cliffs. They are brought to the surface in small areas by the erosion of some of the anticlines or by faulting. - The base of the formation is not exposed but the thickness amounts to 1,000 feet, more or less. The fauna collected from these beds includes small cup corals. Syringopora, Loxonema, Productella, Spirifer centronatus, Chonetes, Euomphalus, and other fossils. According to G. H. Girty, this fauna corresponds to that of the basal portion of the "Wasatch limestone" of the Wasatch Mountains of Utah, as described by the early writers.

UPPER MISSISSIPPIAN LIMESTONE.

Above the Madison limestone, apparently in conformable succession, though the base is not exposed, lies about 1,130 feet of massive light to dark gray limestones, weathering white to light gray. Locally a dark shale zone about 15 feet thick is present near the top. In places also chert nodules occur in concentric and irregular forms, together with streaks of chert. The limestones are in places specked with siderite and seamed with calcite or aragonite and are abundantly fossiliferous at some horizons. The fauna includes large cup corals with many fine septa, Syringopora, Lithostrotion, Martinia, and Productus giganteus. The Martinias form a bed near the top of the formation.

The formation constitutes much of the Preuss Range and is well exposed in Meade Peak, the culminating point of that range. (See PIs: I and IV, A.) No complete section has been measured because of structural interruptions, but future studies in the Ross Fork locality may afford a more favorable opportunity to obtain the uninterrupted sequence, and the selection of a type locality for the formation is deferred for the present.

The authors are also indebted to G. H. Girty for the following faunal list and comments:

An interesting and varied fauna has in places been obtained from the upper part of the upper Mississippian. It is shown by the list of forms collected at station 101 . A short distance below this collection a new species of Martinia was found in countless numbers, constituting a bed a foot thick. Very abundant also in local occurrences is a small variety of Productus giganteus. Large zaphrentoid corals are likewise a feature of the upper Mississippian, being commonly associated with Syringopora and one or more species of Lithostrotion. Some of these colonies are of great size. At this horizon in some places is also found an assemblage of small forms more or less related to the Spergen fauna reported by Meek from Ross Fork. The horizon of all these rather strikingly different facies appears to be below that of station 101 .

$37002^{\circ}-14-2$ 
The following fossils were collected at station 101:

Zaphrentis sp.

Stenopora sp. a.

Stenopora sp. b.

Stenopora? sp.

Batostomella? вp.

Rhombopora? sp.

Productus semireticulatus.

Productus semireticulatus var.

Productus pileiformis.

Productus punctatus var.

Productus aff. longispinus.

Diaphragmus elegans.

Camarophoria wortheni.

Dielasma sp.

Spirifer striatus?

Spirifer increbescens?

Spiriferina sp.

Composita trinuclea?

Edmondia sp.

\author{
Edmondia? sp. \\ Conocardium sp. \\ Schizodus sp. \\ Sphenotus sp. \\ Myalina aff. sanctiludovici. \\ Leptodesma.aff. spergenense. \\ Sulcatipinna ludlowi? \\ Parallelodon? sp. \\ Cypricardinia? sp. \\ Aviculipecten sp. a. \\ Aviculipecten sp. $b$. \\ Aviculipecten sp. c. \\ Pseudomonotis? sp. \\ Lævidentalium venustum? \\ Naticopsis sp. \\ Straparollus similis var. \\ Bulimorpha aff. elongata. \\ Griffithides sp. \\ Phillipsia sp.
}

\section{PEINATSYLVANIAN SERIES.}

WELLS FORMATION.

The upper Mississippian limestone is succeeded by about 2,400 feet of sandy limestones, calcareous sandstones, and quartzites of somewhat variable character. No unconformity has yet been recognized between the underlying formation and these rocks in this field, though Blackwelder ${ }^{1}$ has observed such a relation between the Mississippian and the Pennsylvanian in Utah.

The rocks of this formation occupy the same stratigraphic position as that of the Morgan, Weber, and a portion of the Park City formations of Utah. In the Idaho field, however, these rocks show such variable lithologic features that it has been found impracticable to apply the names Weber and Morgan. Furthermore, Mr. Girty states that from the faunal evidence there is no certainty that these divisions as recognized are actually the equivalents of the formations in Weber Canyon, Utah. On faunal and structural grounds it has been found necessary to include in this formation the calcareous sandstone or siliceous limestone that normally underlies the phosphate shales and has hitherto been included in the Park City formation. ${ }^{2}$ To the groups of strata thus constituted the name Wells formation has been assigned, ${ }^{3}$ from Wells Canyon, in T. 10 S., R. 45 E., where a detailed

\footnotetext{
1 Blackwelder, Eliot, New light on the geology of the Wasatch Mountains, Utah: Geol. Soc. America Bull., vol. 21, p. 530, 1910.

2 Gale, H. S., and Richards, R. W., Preliminary report on the phosphate deposits in southeastern Idaho and adjacent parts of Wyoming and Utah: U. S. Geol. Survey Bull. 430, pp. 457-535, 1910. Richards, R. W., and Mansfield, G. R., Preliminary report on a portion of the Idaho phosphate reserve: U. S. Geol. Survey Bull. 470, pp. 371-439, 1911.

8 Richards, R. W., and Mansfield,-G. R., The Bannock overthrust, a major fault in southeastern Idaho and northeastern Utah: Jour. Geology, vol. 20, pp. 681-709, 1912.
} 
section was measured. The formation here consists of three somewhat variable portions, of which the upper and lower are predominantly calcareous, whereas the middle is mainly sandy.

The lithologic succession above outlined differs from that in Weber Canyon, Utah, where the order, as given by Mr. Girty, who has recently reviewed that section, is white quartzite at the top, succeeded below by gray calcareous sandstone, and at the base red quartzite (Morgan formation).

The following section was measured at the type locality:

Geologic section of beds exposed on north side of Wells Canyon, Idaho.

Wells formation:

Limestone, light brownish gray, sandy, containing Squamularia or Composita and crinoid stems, possibly Productus ....

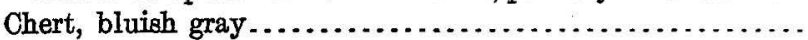

Limestone, light brownish gray, sandy.................

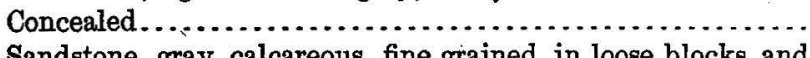

Sandstone, gray, calcareous, fine grained, in loose blocks, and thin beds of quartzite or chert.......................

Concealed.

Feet.

Sandstone, whitish, soft, in loose blocks; weathers like limestone, and contains small quartz-lined geodes; poorly exposed, and partly represented by sandy soil and small fragments

Limestone, light bluish gray, earthy, with considerable dark chert..........................................

Sandstone, yellowish to red, weathered in large rounded blocks. ........................................

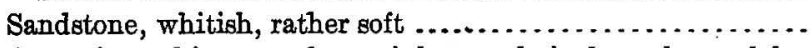

Quartzite, white, weathers pink to red, in large loose slabs, laminated and cross-bedded............................

limestone, in part clear, in part cherty...................

Limestone, dark gray, with large chert concretions; furnished

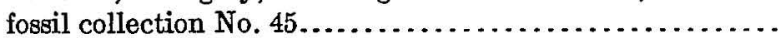

Limestone, sandy, alternating with quartzite and clearer limestone.......................................

Sandstone, whitish, fine grained, one bed ...................

Sandstone, red in part, nearly quartzite, cross-bedded........

Limestone, sandy, with quartz-lined geodes, one bed........

Sandstone, white to reddish, soft; bears abundant Schizophoria and also furnished fossil collections Nos. 28 and 32 from near-by locality ...............................

Sandstone, single bed..............................

Sandstone, thin bedded; furnished fossil collection 101c...... 6

Total thickness, Wells formation.................. $\overline{2,400}$

Upper Mississippian:

Limestone, earthy, with chert in irregular concretions and streaks parallel to bedding.........................

Limestone, light gray to whitish, thin bedded; furnished fos-

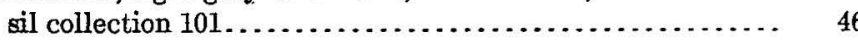

Sandstone, white, calcareous; bears large zaphrentoids....... 14 
Upper Mississippian-Continued. Feet.

Limestone, dark gray, crinoidal; includes a Martinia horizon, about.......................................... 100

Shale and reddish quartzite fragments, about............. $\quad 30$

Quartzite, whitish, outcrops small and scattered; bears small zaphrentoids................................... 270

Concealed..................................... 200

Limestones, gray, in 1 to 3 foot beds; furnished fossil collections. $\quad 450$ Base of upper.Misaissippian not exposed.

Thickness of upper Mississippian exposed............ $\overline{1,130}$
Total thickness of section........................

The principal variations in the three portions of the Wells formation in the area studied are as follows:

The upper member ranges from a maximum thickness of 75 feet to a mere trace. It consists of dense calcareous sandstone grading into siliceous limestone, which weathers into white massive beds that are conspicuous cliff makers (Pl. II, $A$, and VII, $A$, p. 44). Bluish-white chert occurs in bands 2 inches to 1 foot thick and locally in ovate nodules. Toward the base the chert becomes more nodular and darker. Silicified fragments of brachiopods project in little crescents from the weathered surface of the limestone.

Locally the upper member is absent and the overlying Phosphoria formation rests directly upon the more sandy middle member of the Wells formation, which in these places is composed of a breccia of chert and quartzite, similar to that described by Blackwelder ${ }^{1}$ as occurring under similar conditions, and which apparently represents a brief erosion interval at the close of the deposition of the Wells formation.

G. H. Girty says in a personal letter:

The upper part of the Wells formation is usually nearly barren of fossils. Locally large Producti of the semireticulatus group are found, as at station 49 , in the SW. $\frac{1}{4}$ SE. 1 sec. 35 , T. 9 S., R. 45 E., few of them, however, in identifiable condition. Some well-preserved examples obtained at this horizon near Swan Lake, Bannock County, show a form closely allied to Productus ivesi. In that region also a small spiriferoid is very abundant, occurring as silicified fragments which project from weathered surfaces like small arched scales. The specimens of these fossils that can be identified belong to a species of Squamularia related to $S$. perplexa.

The middle portion of the Wells formation comprises 1,700 to 1,800 feet of sandy limestone, in places containing thin beds of quartzite and sandstones. This portion of the formation weathers white, red, or yellow and forms smooth slopes with few projecting ledges (Pl. I). Locally thin limestone beds interstratified with the sandstones have become silicified to dense quartzite bands (Pl. VIII, $A$, p. 45). These rocks may be sparingly fossiliferous, but no fossils have been found in them. Locally a siliceous facies becomes strongly developed and

1 Blackwelder, Eliot, New light on the geology of the Wasatch Mountains, Utah: Geol. Soc. America Bull, vol. 21, p. 532, 1910. 
this portion of the Wells formation is then comparable with the Weber quartzite of Utah.

In the section under discussion sandy and cherty limestones with thin interbedded sandstones are conspicuous in the lower portion of the Wells formation. The maximum observed interval of beds included in this facies is about 750 feet. Within a distance of 2 miles to the north the same interval was found on careful study to comprise only about 100 feet of beds. The cherty limestones are prominent ledge makers and carry a fauna which, according to G: H. Girty, is probably similar in age to, although not specifically identical with, that found in the Morgan formation of Utah. Blackwelder ${ }^{1}$ has described the Morgan formation as composed of red sandstone, shale, and thin intercalated limestones, so that lithologically it is wholly distinct from the cherty limestones described above. G. H. Girty has contributed the following faunal lists of collections from the Wells formation and makes the following comments:

At the very base of the Wells formation a Schizophoria is in many places very abundant, apparently the same species which White identified in New Mexico as S. resupinoides? (lot 101c). A short distance above a more varied fauna is usually found in which a large variety of Spirifer rockymontanus, the same which I identified in Colorado as $S$. boonensis, is specially abundant (stations 28 and 32). Large branching Stenoporas related to $S$. carbonaria are also a feature of this fauna. Another phase of the lower Wells fauna is shown in lot 33. In this assemblage of species Marginifera splendens is extremely common and large branching Stenoporas are also plentiful

Lot 33. Southwest corner of sec. 22, T. 9 S., R. 45 E. From beds about 500 feet above base of Wells formation:
Stenopora wellsiana.
Stenopora gracilis.
Stenopora idahoensis.
Stenopora? sp.
Derbya sp.
Productus cora.
Productus nebraskensis.
Productus semireticulatus.
Marginifera splendens.
Spirifer rockymontanus.
Lot 45 (see section):
Zaphrentis gibsoni.
Monilipora prosseri.
Rhombopora lepidodendroides.
Productus cora.
Productus semireticulatus.
Spirifer cameratus.
Composita subtilita.
Euconospira n. sp.

Lot 28. SE. $\frac{1}{4} \mathrm{sec} .35$, T. 9 S., R. 45 E.:

Spirifer rockymontanus.

Myalina aff. kansasensis.

Aviculipecten sp.

Lot 32 . Same locality as lot 28 , but from beds about 150 feet lower in the section:

Stenopora idahoensis.

Stenopora? sp.

Batostomella? sp.

Derbya sp.

Productus cora.

Spirifer rockymontanus.

Composita subtilita.

Myalina sp.

Lot 10Ic (see section): Schizophoria resupinoides? 
PERMIAN (?) SERIFS.

PHOSPHORIA FORMATION.

The name of the Phosphoria formation is derived from Phosphoria Gulch in T. 10 S., R. 44 E., where the formation is typically exposed. This gulch joins Georgetown Canyon at a distance of $2 \frac{1}{2}$ miles N. $16^{\circ} \mathrm{W}$. of Meade Peak. ${ }^{1}$

The name of the Rex chert member, suggested by $\mathrm{H}$. S. Gale, is derived from Rex Peak in the Crawford Mountains, Rich County, Utah, where the chert forms an anticlinal cap.

The Phosphoria formation is the equivalent of the upper two members of the Park City formation ${ }^{2}$ as heretofore mapped in the phosphate districts of Idaho and Utah, namely, the "overlying chert" and the phosphate shales. These members have also been recognized in the type section ${ }^{3}$ of the Park City in Cottonwood Canyon by H. S. Gale, ${ }^{4}$ who reviewed the section in 1909 , and noted the presence of phosphate rock. Gale regards the upper 129 feet of Boutwell's section as approximately equivalent to the chert member, and the underlying. 112 feet as representing the phosphatic shale interval.

The remaining 194 feet of Boutwell's section is predominantly siliceous, but contains a number of prominent limestone beds and is evidently comparable to the underlying siliceous limestone or calcareous sandstone of the phosphate districts.

The Park City formation was first referred by Boutwell to the Pennsylvanian, but in his later work on the district ${ }^{5}$ he has referred it as a whole doubtfully to the Permian. The lower portion, which contains the bonanzas for which the Park City district is famous and is therefore the important part of the formation, has now, on additional faunal evidence, been referred to the Pennsylvanian. Other reasons for the separation in the Idaho field of the two upper members of the Park City formation from the lowest member are found in the pronounced lithologic differences between this member and the overlying phosphate shales and in the fact that in certain areas in southeast Idaho the phosphate shales rest unconformably on the more siliceous portion of the Wells formation.

\footnotetext{
1 Richards, R. W., and Mansfield, G. R., The Bannock overthrust, a major fault in southeastern Tdaho and northeastern Utah: Jour. Geology, vol. 20, pp. 681-709, 1912.

${ }^{2}$ Boutwell, J. M., Stratigraphy and structure of the Park City mining district, Utah: Jour. Geology, vol. 15, p. 444, 1907. Gale, H. S., and Richards, R. W., Prellminary report on the phosphate deposits in southeastern Idaho, Wyoming, and Utah: U. S. Geol. Survey Bull. 430, p. 475, 1911.

s Boutwell, J. M., loc. cit.

- Personal communieation.

5 Boutwell, J. M., Geology and ore deposits of the Park City district, Utah: U. S. Geol. Survey Prof. Paper 77, 1912.
} 
The Phosphoria formation is also correlated with the upper portion of the Embar formation of Wyoming ${ }^{1}$ and the phosphatic beds above the Quadrant formation of certain areas ${ }^{2}$ in southwestern Montana.

The Rex chert member is the conspicuous portion of the Phosphoria formation, and because of its superior hardness it forms salient topographic features (Pls. II, $B$, and VII, $B$, p. 44). The phosphate shales, on the other hand, are comparatively nonresistant and the development of gulches along them is characteristic. The following table shows the thickness and character of the Rex chert:

Complete section of Rex chert member in sec. 12, T. 10 S., R. 44 E. of Boise meridian.

Feet.

Shale, black, cherty, weathers red $\ldots \ldots \ldots \ldots \ldots \ldots \ldots \ldots \ldots \ldots . .60$

Chert, brown to purple, in heavily iron stained ledges. . . . . . . 60

Limestone, gray, banded, with ashy gray to black chert....... 100

240

Locally 50 to 75 feet above the base the Rex chert gives way to gray limestone, and in other places a dark-gray to black or purplish flinty or cherty shale occupies the major portion of the Rex chert interval, but more generally the shaly facies is present near the top of the section and is in places with difficulty distinguished from the basal portion of the Woodside shale.

The Rex chert is generally nonfossiliferous but locally contains spicules and casts of crinoid stems. G. H. Girty lists the following as the most characteristic species:

Productus multistriatus.

Productus subhorridus.

Spirifer aff. cameratus.

Spiriferina pulchra.
Composita subtilita var.

At a locality on Deer Creek in the Preuss Rarge Mr. Girty obtained the following fauna from the limestone facies of the Rex chert:

Amphoporella laminaria.

Productus nevadensis.

Productus eucharis.

Productus multistriatus (?).

Camarophoria n. sp.

The Rex chert shows considerable range in thickness, so that the width of its outcrop as mapped is not wholly dependent on the inclination of its beds. It ranges from a minimum thickness of about 240 feet in T. 10 S., R. 44 E., to a maximum of about 550 feet in T. 9 S., R. $45 \mathrm{E}$.

The Rex chert locally contains a thin bed of rock phosphate, which is in most places less than 6 inches in thickness.

\footnotetext{
${ }^{1}$ Darton, N. H., Paleozoic and Mesozoic of central Wyoming: Bull. Geol. Soc. America, vol. 19, p. 416, 1908. Blackwelder, Eliot, A reconnaissance of the phosphate deposits in western Wyoming: U. S. Geol. Survey Bull. 470, p. 459, 1911.

'Gale, H. S., Rock phosphate near Melrose, Mont.: U. S. Geol. Surrey Bull. 470, pp. 440-451, 1911. Blackwelder, Eliot, New light on the geology of the Wasatch Mountains, Utah: Geol. Boc. America BuH., vol. 21, pp. 517-532, 1910.
} 
The remaining portion of the Phosphoria formation, the basal division, consists of 75 to 180 feet of yellowish to brown phosphatic sandstones and shales, with one to three important beds of oolitic rock phosphate and in some places dark-colored fetid limestones in beds and lenses. The limestones are from 3 inches to 2 feet thick.

The fauna of the phosphate shales is extensive and has been studied by G. H. Girty, who has selected the following characteristic list from his bulletin ${ }^{1}$ on the subject:

Lingula carbonaria (?).

Lingulidiscina missouriensis.

Chonetes ostiolatus.

Productus geniculatus.

Productus eucharis.

Productus montpelierensis.

Productus phosphaticus.

Pugnax weeksi.
Pugnax osagensis var. occidentalis. Ambocœlia arcuata.

Leda obesa.

Plagioglypta canna.

Omphalotrochus ferrieri.

Omphalotrochus conoideus.

Hollina emaciata var. occidentalis.

The following section of the phosphate shales, measured in 1909 in Georgetown Canyon, is on the whole the most satisfactory one obtained in the western fields and shows the maximum phosphate content, both in high-grade and low-grade material.

Section of basal portion of Phosphoria formation in Georgetown Canyon (SE. $N W . \frac{1}{1}$ sec. 30, T. 10 S., R. 45 E. of the Boise meridian), Idaho.

[Land lines theoretical.]

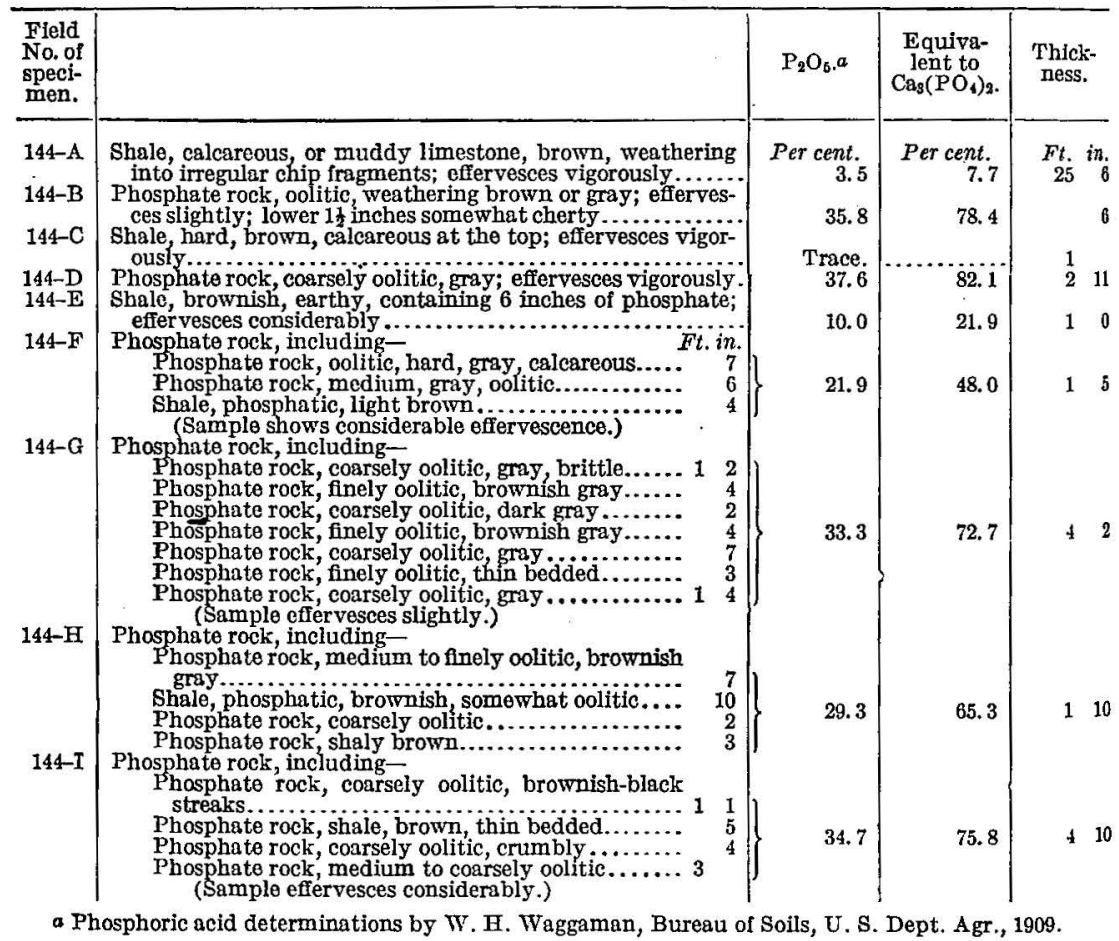

1 Girty, G. H., The fauna of the phosphate beds of the Park City formation in Idaho, Wyoming, and Utah: U. S. Geol. Survey Bull. 436, 1910. 
Section of basal portion of Phosphoria formation in Georgetown Canyon (SE. $N W . \frac{1}{4}$ sec. So, T. 10 S., R. 45 E. of the Boise meridian), Idaho-Continued."

\begin{tabular}{|c|c|c|c|c|}
\hline $\begin{array}{l}\text { Fiold } \\
\text { No. of } \\
\text { speci- } \\
\text { men. }\end{array}$ & & $\mathrm{P}_{2} \mathrm{O}_{5}, a$ & $\begin{array}{l}\text { Equiva- } \\
\text { lent to } \\
\mathrm{Ca}_{3}\left(\mathrm{PO}_{4}\right)_{2}\end{array}$ & $\begin{array}{l}\text { Thick- } \\
\text { ness. }\end{array}$ \\
\hline $144-\mathrm{K}$ & 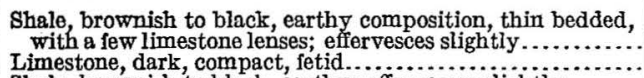 & $\begin{array}{r}\text { Per cent. } \\
.24 .2\end{array}$ & $\begin{array}{l}\text { Per cent. } \\
53.0\end{array}$ & Ft. in. \\
\hline${ }_{144-\mathrm{M}}^{144-\mathrm{L}}$ & Shale, brownish to black, earthy; effervesces slightly...................... & iii. 7 & 25.6 & 12 \\
\hline \multirow[b]{2}{*}{$\begin{array}{l}144-N \\
144-0\end{array}$} & 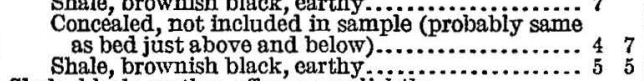 & 15.1 & 33.1 & 17 \\
\hline & 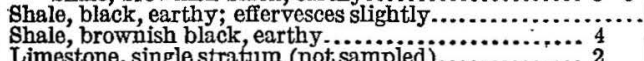 & 19.9 & 43.6 & 12 \\
\hline 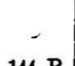 & $\begin{array}{l}\text { Limestone, single stratum (not sampled) } \ldots \ldots \ldots \ldots \ldots \ldots 2 \\
\text { Shale, brownish black, earthy........................... } \\
\text { Limestone, single stratum (not sampled)........... }\end{array}$ & 21.2 & 46. 4 & 12. 0 \\
\hline $144-P$ & $\begin{array}{l}\text { Shale, black and dark brown, calcareous, earthy; } \\
\text { considerably } \ldots . . . \ldots \ldots \ldots \ldots\end{array}$ & \multirow{2}{*}{25.8} & \multirow{2}{*}{56.3} & \multirow[t]{2}{*}{6} \\
\hline $144-Q$ & Shale, black and dark brown, calcareous, earthy; effervesces & & & \\
\hline 144-R & 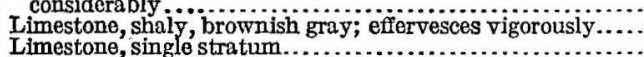 & $\begin{array}{l}24.6 \\
17.8\end{array}$ & $\begin{array}{l}53.9 \\
39.0\end{array}$ & $\begin{array}{rr}12 & 0 \\
4 & 10 \\
2 & 11 \\
2\end{array}$ \\
\hline \multirow{3}{*}{$\begin{array}{l}144-S \\
144-T\end{array}$} & 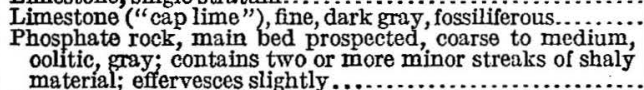 & \multirow{3}{*}{$\begin{array}{r}36.8 \\
3.7\end{array}$} & \multirow{3}{*}{$\begin{array}{r}80.4 \\
8.1\end{array}$} & \multirow{2}{*}{6} \\
\hline & $\begin{array}{l}\text { Shale, brown, earthy; effervesces slightly } \\
\text { Limestone, massive, underlying the phosphatic series. }\end{array}$ & & & \\
\hline & & & & 13911 \\
\hline
\end{tabular}

About $2 \frac{1}{2}$ miles north along the same outcrop of the Phosphoria formation another detailed section was measured in 1911. Samples for the determination of phosphoric acid were taken from the upper portion only, as it appeared to afford a better exposure of that part of the formation than had been obtained in the preceding section. It will be noted that this section contains about 40 feet more of the phosphate-bearing beds. The phosphate content of that part of the section from which no samples were taken is inferred from visual examination to be about the same as that found in the section given above.

Section of basal portion of Phosphoria formation in SE. $\frac{1}{4}$ sec. 7, T. 10 S., R. 45 E. of the Boise meridian, Idaho.

[Land lines theoretical.]

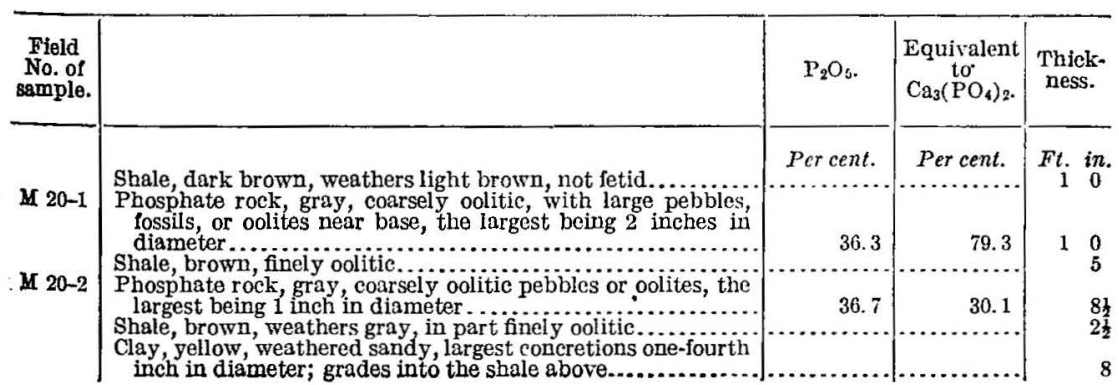


Section of basal portion of Phosphoria formation in SE. 1 sec. 7, T. 10 S., R. 45 E. of the Boise meridian, Idaho-Continued.

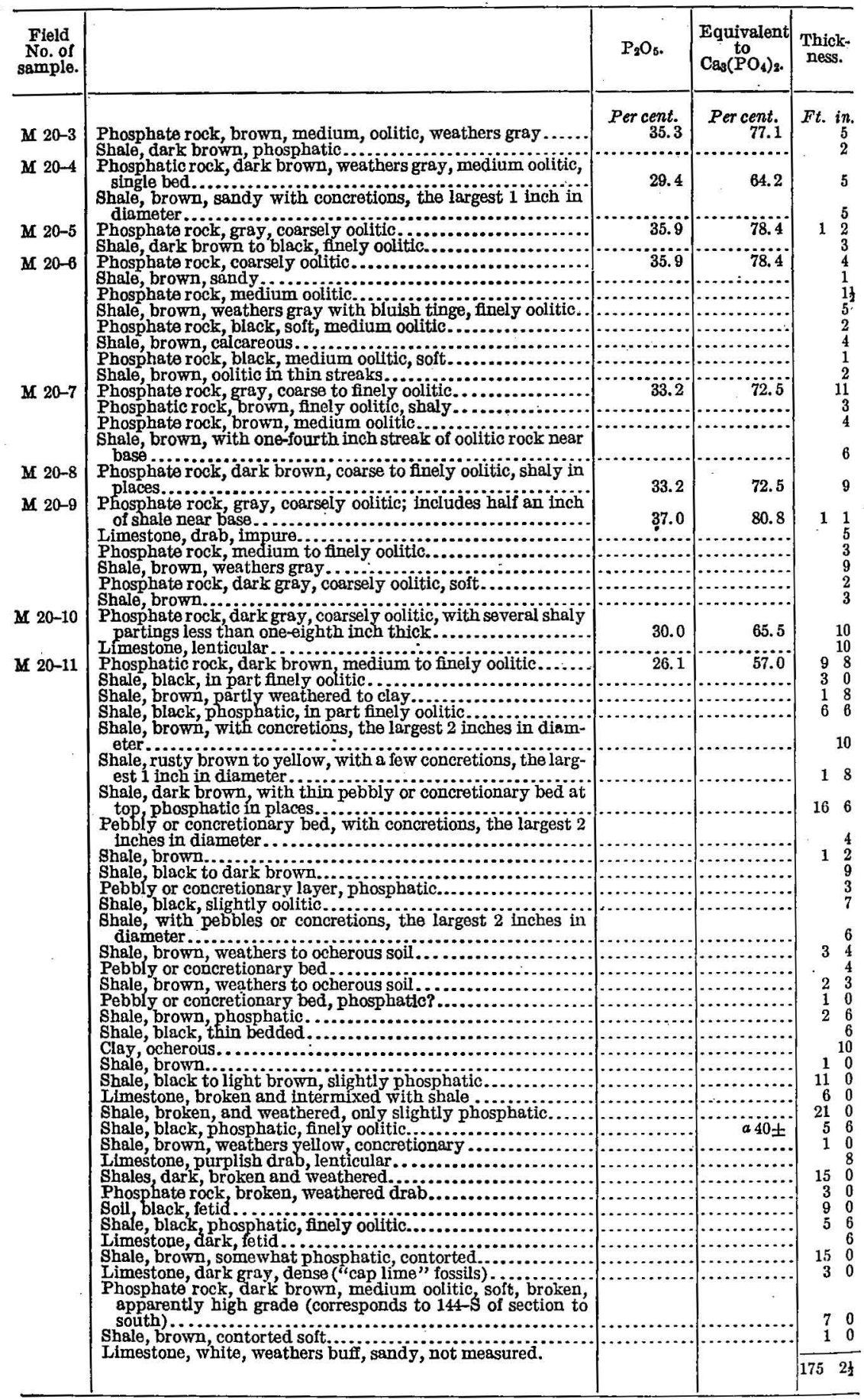

a Estimated. 
Prior to this examination by the United States Geological Survey no prospecting had been done on the phosphate beds north of the above section. In the course of this investigation cuts were made across the main phosphate-bearing portion of the Phosphoria formation at two localities; namely, in sec. 16, T. 9 S., R. 44 E., and sec. 14, T. 8 S., R. 44 E. The sections follow:

Section of lower and phosphate-bearing strata of Phosphoria formation in the NW. $\frac{1}{4}$ NE. 1 sec. 16, T. 9 S., R. 44 E. of the Boise meridian, Idaho.

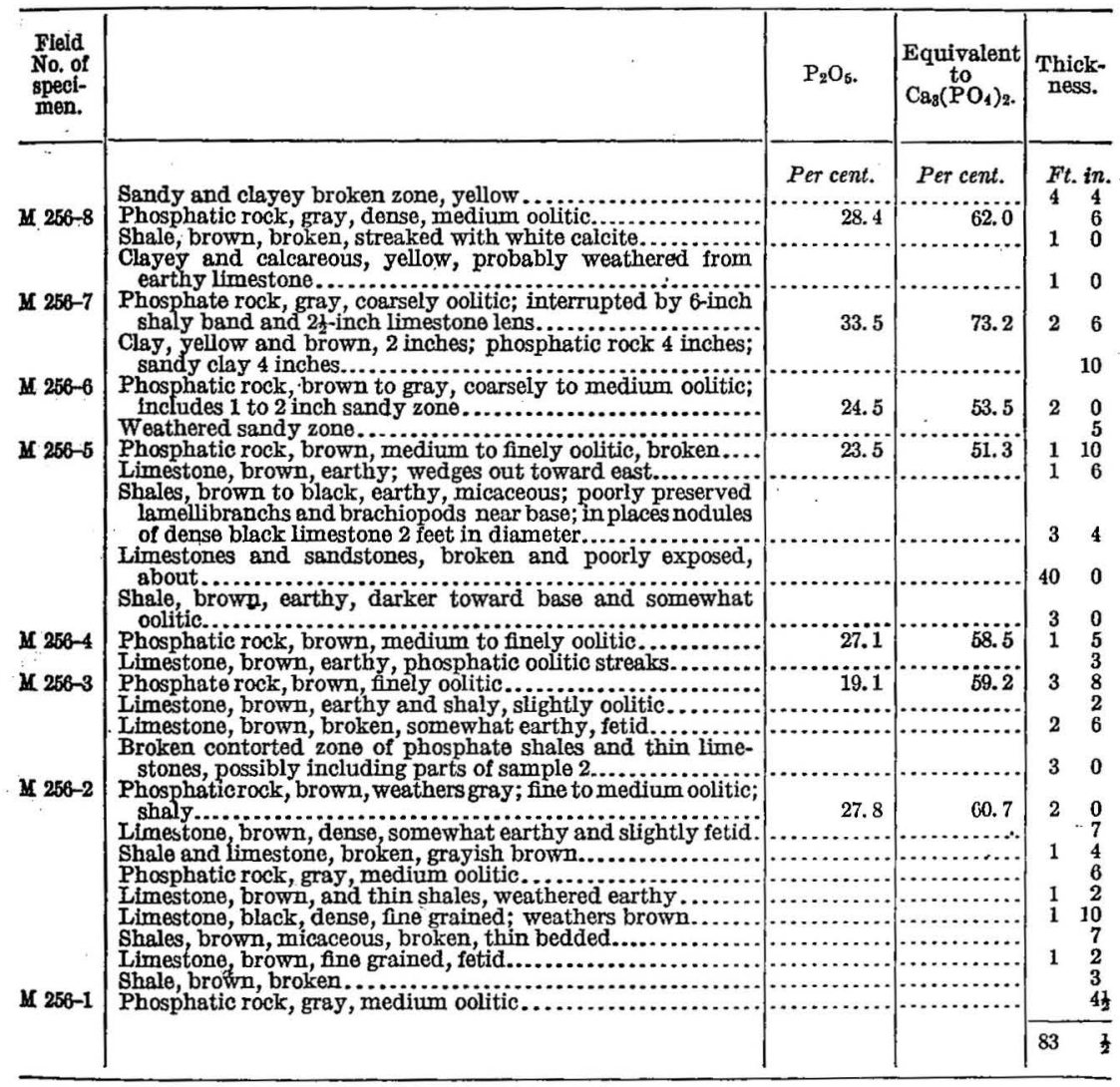


Nearly complete section of phosphate shales of Phosphoria formation in the $S W . \frac{1}{4} S E$. sec. 14, T. 8 S., R. 44 E. of the Boise meridian, Idaho.

\begin{tabular}{|c|c|c|c|c|}
\hline $\begin{array}{l}\text { Field } \\
\text { No. } \\
\text { of speci- } \\
\text { men. }\end{array}$ & & $\mathrm{P}_{2} \mathrm{O}_{5}$ & $\begin{array}{l}\text { Equivs- } \\
\text { lent to } \\
\mathrm{Ca}_{3}\left(\mathrm{PO}_{4}\right)_{2}\end{array}$ & $\begin{array}{l}\text { Thick- } \\
\text { ness. }\end{array}$ \\
\hline$M=707$ & $\begin{array}{l}\text { Remainder of section to chert covered by aspens and brush. } \\
\text { Limestones and shales; weathered brown. } \\
\text { Limestone... }\end{array}$ & Per cent. & $\begin{array}{l}\text { Per cent. } \\
\end{array}$ & \multirow{2}{*}{$\begin{array}{cc}\text { Ft. in. } \\
10 \pm \\
8 & 0 \\
& 6 \\
1 & 8 \\
& 6\end{array}$} \\
\hline M $307-7$ & 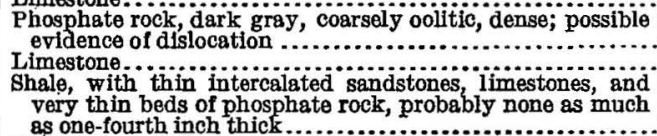 & 36.0 & 78.6 & \\
\hline M. 307-6 & 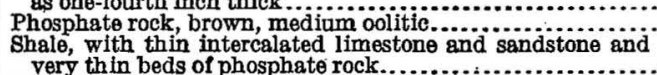 & 28.4 & 62.0 & \multirow{3}{*}{$\begin{array}{rr}128 \\
1 & 10 \\
21 & 0 \\
3 & 0 \\
2 & 5 \\
8 & 4 \\
2 & 7 \\
3 & 0 \\
3 & 0 \\
5 & 2 \\
& 3\end{array}$} \\
\hline$\frac{M}{M} 307-5$ & 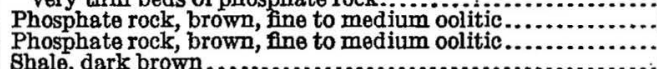 & $\begin{array}{l}29.7 \\
31.5\end{array}$ & $\begin{array}{l}76.9 \\
68.8\end{array}$ & \\
\hline $\begin{array}{l}\mathrm{M} \\
\mathrm{M} \\
\mathbf{M} \\
307-2 \\
307-1\end{array}$ & 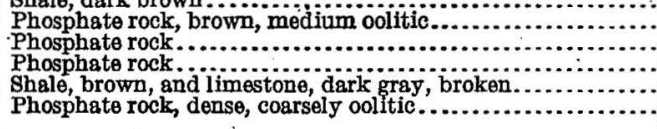 & \begin{tabular}{r|}
31.5 \\
32.6 \\
31.0
\end{tabular} & $\begin{array}{r}68.8 \\
7.2 \\
67.7 \\
\cdots\end{array}$ & \\
\hline & & & & 1933 \\
\hline
\end{tabular}

A comparison of these seetions with the two preceding sections shows in some respects a marked similarity but in others a pronounced difference. The higher-grade beds lie near the bottom and near the top of the lower portion of the Phosphoria formation. There is; however, a variation both in thickness of beds and quality of the rock phosphate. It appears that a bed not over 3 feet thick generally occurs near the top of the phosphate shales, whereas at the base, according to the best exposure, that of the section last given, the bed may well be expected on further exposure to contain as much as 8 feet of rock containing about 70 per cent tricalcium phosphate. The minimum thickness ( $4 \frac{1}{2}$ inches), found in the section given on page 27 , is regarded as partial and as being due to the cutting out of the upper portion of the bed by a slight local slip, a disturbance which is indicated by the broken condition of the overlying shale.

In 1909 another section was measured on a small tributary of Slug Creek near the west boundary of T. 8 S., R. 44 E. 
Complete section of phosphate-bearing strata of Phosphoria formation on tributary of Slug Creek (in the SW. $\frac{1}{6} S W .+\frac{1}{4}$ sec. 7, T. $8 S$., R. $44 E$. of the Boise meridian), İdaho.

\begin{tabular}{|c|c|c|c|c|}
\hline $\begin{array}{l}\text { Field } \\
\text { No. } \\
\text { of speci- } \\
\text { men. }\end{array}$ & & $\mathrm{P}_{2} \mathrm{O}_{3}$. & $\begin{array}{c}* \\
\text { Equiva- } \\
\text { lentt to } \\
\text { Cas }^{2}\left(\mathrm{PO}_{4}\right)_{2}\end{array}$ & $\begin{array}{l}\text { Thick. } \\
\text { ness. }\end{array}$ \\
\hline & Sandstone, white, fine grained; weathers brown. & Per cent. & Per cent. & Ft. \\
\hline R 378-6 & Shale, brown, sandy, with limestone lenses........ & $\cdots$ & $\cdots$ & 47 \\
\hline R $378-5$ & 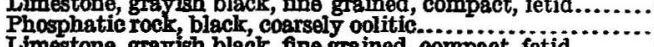 & 26.3 & $\ddot{5} 7.0 .5$ & $\stackrel{5}{1}$ \\
\hline & Shale; brown, with some oolitio streaks. & & & \\
\hline & $\begin{array}{l}\text { Limestone, graysish black, tine grained, com } \\
\text { Shale, brown, with some oolitio streaks... }\end{array}$ & & & \\
\hline R $378-4$ & Phosphate rook, grayish black medium oolitic................. & 33.5 & 73.2 & \\
\hline R 378-3 & 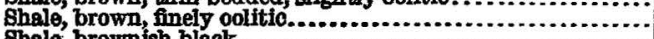 & & & \\
\hline & 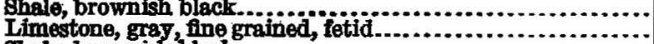 & 6.6 & 14.4 & \\
\hline \multirow{3}{*}{$\begin{array}{l}\text { R. 378-2 } \\
\text { R } 378-1 a \\
R \quad 378-1\end{array}$} & 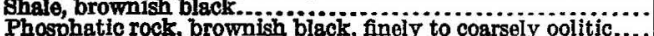 & 29.4 & 64.3 & 7 \\
\hline & 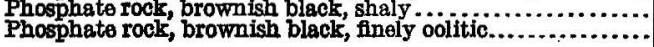 & $\begin{array}{l}17.2 \\
27.5\end{array}$ & 60.1 & \\
\hline & & & & 767 \\
\hline
\end{tabular}

Of the sections measured this one is by far the poorest in phosphatic material, but the richer sections to the west and east indicate that the variation is a local rather than a general change in the character of the deposits.

The Phosphoria formation, so far as at present known, occurs only in portions of southeastern Idaho, northeastern Utah, and southwestern Montana.

\section{TRIASSIC SYSTEM.}

WOODSIDE SHATE.

The Woodside shale, which immediately overlies the Phosphoria formation, is so called by correlation with the section in the Park City mining district, Utah. It is composed mainly of thin-bedded, platy, somewhat sandy shale with intercalated sandy limestones, and it contrins heary beds of limestone at the top. Unlike the Woodside shale of the Utah section, the formation within this area does not contain red beds. The great mass consists of the thin beds above mentioned, which have yellowish to olive-greenish tints and firm texture. The rock is hard enough.when fresh to ring under the hammer and weathers to yellowish or brownish colors.

The base of the Woodside is in most places quite distinct, for the Rex chert member of the underlying Phosphoria formation is generally represented by massive chert ledges topographically prominent. But even where the ledges are absent the chert fragments below can on close examination be distinguished from the Woodside shale fragments above.

The limestone at the top of the Woodside shale closely resembles the overlying Thaynes limestone. The upper limit of the Woodside 
has been somewhat arbitrarily placed at the layer immediately below the Meekoceras zone. This delimitation seems desirable, because without subdivision the combined Woodside and Thaynes formations would be nearly 4,000 feet thick and because the Meekoceras zone marks the entry of the first ammonites recognized in the faunas of these formations. Minor lithologic differences also exist between the rocks of the Meekoceras zone and those below. The upper part of the Woodside is composed of heavy ledges of whitish to gray massive limestones, which in some zones are crowded with fossils, principally species of Myalina. These limestones make fine ledges that form pronounced gateways in some of the canyons. The uppermost members of the heavy-bedded limestones pass into those containing Meekoceras with no perceptible stratigraphic break. The thickness of the Woodside shale ranges from about 1,000 to 1,800 feet.

Topographically the Woodside shale is generally marked by smooth, rounded hills with few ledges, except where the upper members are exposed.

THAYNES LIMESTONE.

The Thaynes limestone, which overlies conformably the Woodside shale, takes its name from Thaynes Canyon, near Park City, Utah. It contains marine fossil shells at many horizons and from the occurrence of certain ammonoids (Meekoceras fauna) at its base it has been assigned by Hyatt and Smith to the Lower Triassic." The "Meekoceras beds," where recognized by the Hayden Survey, were referred to the Triassic.

The Meekoceras zone at the base of the formation consists of whitish to gray limestones 10 to 25 feet thick, crowded with ammonites, whose chambered shells are conspicuous on the weathered surfaces of the rock. This zone, though not apparently continuous, is fairly constant in the portions of the area occupied by the Thaynes limestone within the region considered in this report. Two other important ammonite horizons, the Tirolites and Columbites zones, have been recognized by Smith in the Thaynes limestone in Paris Canyon, Idaho, a part of the region described in the report for 1910 . The Tirolites zone is included in gray calcareous shales carrying forms listed under the Tirolites fauna about 250 feet above the Meekoceras zone. The Columbites zone lies about 25 feet above the Tirolites zone and occurs in a thin bed of brownish bituminous limestone containing the Columbites fauna. ${ }^{2}$ In the region considered in this report the Tirolites and Columbites zones have not been definitely

\footnotetext{
1 Hyatt, Alpheus, and Smith, J. P., The Triassic cephalopod genera of America: U. S. Geol. Survey Prof. Paper 40, pp. 17 et seq., 1905.

2Smith, J. P., The distribution of Lower Triassic faunas: Jour. Geology, vol. 20, p. 17, 1912.
} 
recognized; but at two localities, in the SE. $\frac{1}{4}$ sec. 1; T. 8. S., R. 44 E.; and in the SE. $\frac{1}{4}$ sec. 3, T. 9 S., R. 45 E.; ammonites were found which may prove to be representatives of these horizons. In the locality in township 9 the ammonites occurred in dark nodular masses of limestone in light calcareous shales similar to those of the Paris Canyon section.

The lithology of the Thaynes limestone in most of the area described in this report is much like that of the limestones at the top of the Woodside, but for 200 feet or more above the base the rocks are less sandy and more clayey and have a well-defined grayish color, different from the yellowish and greenish tints of the Woodside. This feature is a helpful indicator where the Meekoceras zone is not well developed. The limestones contain much clay and sand, so that on weathering they assume a sandy or muddy aspect, which makes it difficult in many places to distinguish them from sandstones except on fresh fractures. No complete section of the Thaynes limestone has been found in this region, but at Raymond Canyon, Wyo., and in Montpelier Canyon it has a thickness of about 2,000 feet.

\section{ANKAREH SHALE.}

The Ankareh shale, which overlies the Thaynes limestone with apparent conformity elsewhere in Idaho, Wyoming, and Utah, has not been definitely recognized in this area. Possibly, however, certain beds in T. 11 S., R. 45 E., which are assigned to the Nugget in this report, may be referable to the Ankareh. As originally described from the Park City section, exposed in Big Cottonwood Canyon, near Salt Lake City, it consists chiefly of clay shale of deep maroon or chocolate color, massive where fresh but commonly breaking down after exposure into thinner-bedded shaly material. It includes also some pale-greenish clayey and sandy strata, beds of mottled green and maroon shale, and harder layers of red or greenish sandstone and limy strata, and in the Montpelier district is defined at the top and bottom by massive limestones. The limestone or calcareous shale at the top distinguishes the Ankareh to the south from the massive sandstones and red sandy shales of the Nugget sandstone. The limestone at the base of this "red bed" formation is the uppermost of the massive beds that constitute the more prominent part of the Thaynes limestone. The total thickness of the Ankareh as measured in the Montpelier district is about 670 feet, including the limestone at the top, but excluding the massive underlying sandstone strata more properly classed with the main body of the Thaynes. The thickness in this area is probably about the same as in the Montpelier district. 
JURASSIO OR TRIASSIO ROCKS.

NUGGET SANDSTONE.

As described in a previous report, ${ }^{1}$ the Nugget sandstene, which overlies the Ankareh shale in areas where the Ankareh is present, is composed chiefly of massive reddish sandstone, locally deeply colored and in places much cross-bedded. The Nugget sandstone includes also intervals of sandy shale; which are generally obscured by talus of the more massive strata. At its base lies a white conglomeratic sandstone, and in some areas several hundred feet of white sandstone form the upper part. In this area the base of the formation is not exposed. The sandstone as a whole is fairly uniform in color and texture and is more or less silicified to quartzite. In Tps. 10 and 11; R. $44 \mathrm{E}$., the upper part of the formation is marked.by deep-red sandy and shaly beds with two or more massive beds of gray limestone. Owing to its massive resistant character, the Nugget sandstone forms high ridges with broad rounded slopes or in exposures it is marked by heavy talus of brown or black weathering blocks. Its thickness has not been measured in this area. In Raymond Canyon a thickness of 1,900 feet was observed.

No fossils have been found in the Nugget sandstone, but as it lies below the marine Jurassic of the Twin Creek limestone and above the beds from which the Triassic ammonoids of Hyatt and Smith were obtained, its position leads to the conclusion that it is either Triassic or Lower Jurassic. It is thought to be in greater part the stratigraphic equivalent of the White Cliff and Vermilion Cliff sandstones of the Uinta Mountains, and if so there is some probability that at least its upper part may be Jurassic.

JURASSIC SYSTEM.

TWIN CREEK LIMESTONE.

The Twin Creek limestone, which overlies the Nugget sandstone, consists principally of grayish-white shaly limestones that form steep slopes covered by a veneer of chippy and splintery weathered pieces. In some places the limestone is less shaly and the beds are more massive. Fossiliferous strata here and there show that the formation is marine and of Jurassic age. The base and the top of the formation are bounded by red beds and are well defined. No continuous section suitable for measurement has been found, but the total thickness in this area is probably 3,000 feet or more. Characteristic exposures of the Twin Creek limestone are shown in Plate IV (p. 38).

No occurrence of phosphate rock in this formation other than that discovered by Gale and noted in the report ${ }^{2}$ published in Bulletin

1 Gale, H. S., and Richards, R. W., Preliminary report on the phosphate deposits in southeastern Idaho and adjacent parts of Wyoming and Utah: U. S. Geol. Survey Bull. 430, P. 4S0, 1910.

U. S. Geol. Survey Bull. 430, p. 508, 1910. 
430 has been observed. The base of the Twin Creek limestone, according to measurements recorded in that report, lies about 6,500 feet above the Paleozoic phosphate beds, so that when this and later formations occupy the surface in normal and unfaulted positions the phosphate lies too deep for recovery under present conditions.

\section{CRETACEOUS AND JURASSIC ROCKS.}

\section{BECEWITH FORMATIOF.}

The Beckwith formation overlies the Twin Creek limestone and is extensively exposed in the southeastern and eastern parts of the area. The boundary between the two formations is in part at least a fault. The lower members of the formation are sandstones of a reddish or chocolate-brown color with some whitish or grayish beds. Above these lie red conglomerates with heavy ridge-making layers. The upper part of the formation is not present in the area discussed in this report and no measurements of the section were made. According to Breger ${ }^{1}$ the lower 1,200 feet consist of red sandstones and shales without conglomerates. These rocks are overlain by greenishgray calcareous sandstones 250 to 600 feet thick. These sandstones are succeeded by 850 feet of red conglomerates, and these in turn by a massive gray limestone 100 feet or less in thickness. The formation is well exposed in Red Mountain just east of T. 11 S., R. $45 \mathrm{E}$.

\section{TERTIARY SYSTEM.}

PLIOCENE (?) ILIESTONES AND CONGIONERATES.

Marls, marly limestones, calcareous grits, and calcareous conglomerates, of probable Pliocene age, which were included in the Salt Lake group of Hayden ${ }^{2}$ and Peale, ${ }^{3}$ locally cover the older rocks. The principal area of these deposits is found in the foothills north and east of Georgetown. On the west side of Slug Creek in T. 9 S., R. $44 \mathrm{E}$., and in the northeast corner of T. $11 \mathrm{~S}$., R. $45 \mathrm{E}$., other fairly large areas of these rocks are present. Small patches were also noted in T. 10 S., R. 44 E.

These Pliocene (?) deposits have been disturbed in the deformation of the region and locally dip nearly $60^{\circ}$.

\section{QUATERNARY SYSTEM.}

cLaYs.

On the east side of Crow Croek in T. 10 S., R. 45 E., red stony clays make up a terrace-like area. The clays have been described by Breger, ${ }^{4}$ who regards them as probably of Pleistocene age. This view is tentatively accepted in this report.

\footnotetext{
I Breger, C. I., Salt resources of Idaho-Wyoming border: U. S. Geol. Survey Bull. 430, pp. 562-563, 1909.

Hayden, F. V., U. S. Geol. and Geog. Survey Terr. Fifth Ann. Rept., pp. 154, 155, 1872.

Peale, A. C., U. S. Geol. and Geog. Survey Terr. Eleventh Ann. Rept., pp. 588, 640, 1879.

- Breger, C. L., op. cit. $37002^{\circ}-14-3$
} 
SPRING DEPOSITS AND SALT.

Deposits of travertine and numerous springs are found in the southeastern portion of the area, in the valley of Crow Creek and along the trace of the Bannock overthrust. The water of some of these springs is heavily charged with sodium chloride (common salt). The origin and value of these saline deposits has been discussed by Breger. ${ }^{1}$ The writers are inclined to think that the surface of the overthrust has played an important part in the localization of the salines, but they can not in this paper enter into a detailed discussion of the problem.

\section{ALLUVIUM.}

The floors of the several basins are concealed at unknown depths by the cover of alluvium. In the larger basins, as Slug Creek valley and Dry Valley, where the alluvial filling is thick and the underlying structure complicated by folds or faults, the alluvial deposits render the character and position of the phosphate beds problematical. The fan deposits along the sides of the larger valleys are included with the alluvium, the fans on the east side of Dry Valley being particularly well developed.

\section{IGNEOUS ROCKS.}

A small body of basalt along the boundary between Tps. 9 and 10 S., R. 44 E., is the only igneous rock observed within the area examined. The rock is somewhat vesicular, dark colored, and fine grained and weathers brown. Its mineralogic constitution is not wholly apparent to the naked eye. However, a few inconspicuous phenocrysts of augite and olivine are seen with difficulty. In thin section the groundmass is found to consist mainly of glass inclosing plagioclase, augite, olivine, and magnetite.

The area appears to represent an outlier of the extensive flows which lie to the north and west. The rock is believed to be of late Pliocene or early Pleistocene age, judging from its relations to the Pliocene (?) limestone and conglomerate.

\section{STRUCTURE.}

\section{GENERAL FEATURES.}

The area surveyed comprises two folded and discordantly related structural units, which originally were distant portions of the same folded sedimentary complex. The present discordance between the units is due to major overthrust faulting, which is believed to have transposed the mass of Carboniferous rocks containing the valuable phosphate deposits eastward over beds which are normally from 6,000 to 12,000 feet higher in the geologic column. 
The effect of this great crustal readjustment extends beyond the area described in this report.

\section{BANNOCK OVERTHRUST. ${ }^{1}$}

CHARACTERISTIC FEATURES.

The fault produced by the crustal readjustment has been named the "Bannock overthrust" from its typical development in Bannock County, Idaho. From the north fork of Georgetown Canyon (left fork of Twin Creek), where the fault emerges from beneath the late conglomerates, its sinuous course was followed across the Prouss Range into Crow Creek as far as the mouth of Sage Creek (Pls. I, III, and IV), a distance of approximately 35 miles, beyond which it appears to continue northward.

The sinuosity of the fault trace is due not only to erosion but also to deformation. In the north fork of Georgetown Canyon an anticlinal axis has arched the thrust surface or plane, so that it has been partly removed, and the underlying Nugget and Twin Creek formations are exposed in the valley, though long strips of heavy Mississippian limestone reach down the spurs of the rijdges (Pl. III). A synclinal axis depresses the thrust surface where it passes beneath the Preuss Range in the headwaters of Montpelier Creek. In this region there is a marked contrast between the massive castellated Mississippian limestones that constitute the upper part of the ridge and the chippy and shaly limestones of the Twin Creek formation that are exposed along the lower slopes of the valley side.

The structural relations produced by the Bannock overthrust are illustrated in the structure section $A-B$ (fig. 3 and Pl. III). The profile and distances shown in the section are based on the topographic map rather than on the stereogram.

In Georgetown Canyon and southeast across the Preuss Range the relations are the same. The underlying Twin Creek strata are folded, so that the stratigraphic throw can not be measured with accuracy, but the missing formations, including Pennsylvanian to Triassic rocks (Nugget), represent a minimum vertical displacement of about 8,500 feet. Eastward the throw apparently diminishes, partly on account of branching faults and partly on account of the folded structure of the rocks in the upper block.

The general trend of the trace of the fault appears to be a few degrees west of north and the direction of thrust a little north of east. The dip of the fault surface gives little aill in determining the direction of movement because of its present deformed condition. Theolder rocks, however, lie to the west and the thickness of the thrust block appears to increase in that direction.

\footnotetext{
${ }^{1}$ Richards, R. W., and Mansfield, G. R., The Bannock overthrust, a major fault in southeastern Idaho and northeastern Utah: Jour. Geology, vol. 20, pp. 681-709, 1912.
} 
The distance, perpendicular to the general trend, between the westernmost observed portion of the fault trace in Georgetown
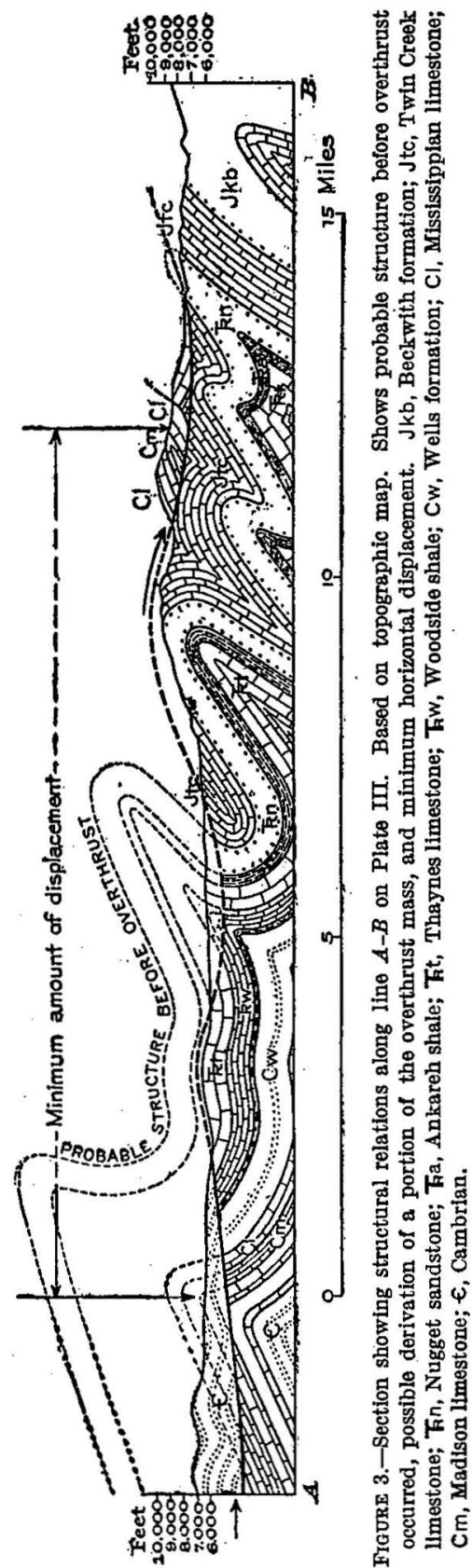

Canyon and the easternmost portion of that trace in Crow Creek is about 12 miles. It appears, therefore, that the heave may be equal at least to that distance.

In the ridge west of Slug Creek an elongate area apparently surrounded by a fault boundary is interpreted as an anticlinal portion of the main thrust or of a subordinate thrust, unroofed by erosion so that the underlying block is exposed through a "window" or "fenster" (Pl.III). The position of this window with reference to the anticline in the north fork of Georgetown Canyon is favorable to this interpretation.

This discussion of the structure is naturally divided into two parts, namely, the discussion of the overlying or overthrust block, and that of the basal or underlying block.

The underlying block is exposed in the southern half of the area and is made up at the surface of the Nugget sandstone, the Twin Creek limestone, and the Beckwith formation. The oldest of these formations, the Nugget sandstone, is exposed only along anticlinal crests, whereas the two younger formations are included in the synclinal folds (Pl. IV, B). The folded beds are overturned toward the east, and the folds are complex rather than as simple as suggested by the omission of lithologic details in the structure sections accompanying the geologic maps (Pls. V, VI, IX-XIV).

The constitution of the unexposed portion of the underlying block beneath three-fourths of the entire area surveyed is of necessity a matter of inference from the character of the block as exposed along the eroded margins of the overthrust. For this region a statement 


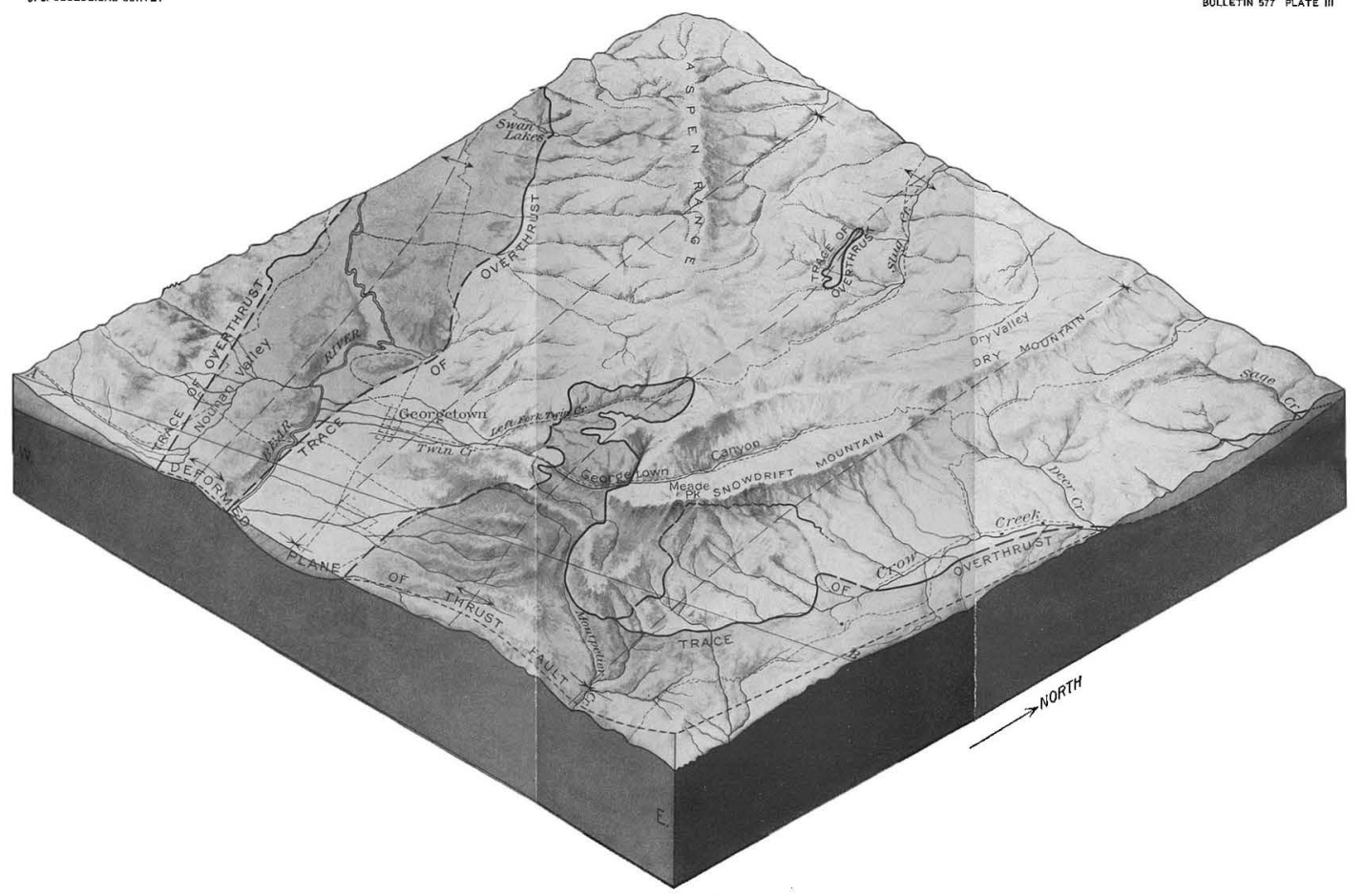

STEREOGRAM OF TPS. 9-11 S., RS. 43-45 E., OF REgion TRAVERSED BY BANNOCK OVERTHRUST. Movement was in general from west to east. Note deformation of thrust plane. A-B, Line of section shown in figure 3, page 35 

has already been made, and for the area lying to the east and north data are included in the reconnaissance report by Schultz and Richards: 1 The formations here exposed range from the Ankareh shale to the Beckwith formation. It appears, on the whole then, that these higher formations are most apt to make up the surface of the underlying block at its concealed contrict with the overthrust block. It is suggested, however, that irregularities in the pitch of the folds may locally bring the lower rocks up to the fault plane, and it is thought that an example of this phenomenon is found in the peculiarly shaped fault-bounded outcrop of the sandy limestones and quartzites of the Wells formation, in secs. 17, 20, 21, and 28, T. 9 S., R. 44 E. The possibility that this effect is produced by the outsrop of a branch of the main thrust which has transgressed into the upper fault block offers a satisfactory alternative explanation of the relations shown in the field.

The structure of the overlying block is of particular importance because it determines to a large extent the distribution of the phosphate beds. The abundance of data regarding the outcrop renders the interpretation of the structure of this block much easier and more certain than that of the block previously discussed.

The rocks outcropping in the overthrust block are mainly sedimentary, ranging from the Madison limestone nearly to the top of the Thaynes limestone, and to the north of the area some rocks as high as the Beckwith formation are included. A small area of basaltic rocks is present in secs. 33 and 34, T. 9 S., R. 44 E., and secs. 3 and 4, T. 10 S., R. 44 E.

The broader structural features comprise a series of anticlinal and synclinal folds whose trend curves from approximately N. $20^{\circ} \mathrm{E}$. in the southern part of the block to nearly N. $45^{\circ}$ W. at the north boundary. The eroded and faulted remnants of four synclines and five anticlines represent the larger folds. In general the anticlines are smaller and sharper than the intervening synclines. The comparative widths of the anticlines and synclines are due mainly to the general attitude of the folds; as the folds plunge toward the north the synclines become broader, and as they rise toward the south the synclines become narrower and the older rocks which form the remnants of the anticlines, occupy the greater part of the area.

MAGNTTUDE OF'THE BANTOCK OVRRTHRUST.

In the above description only a portion of the Bannock overthrust has been considered. The study of the great fault within the area discussed in this report has led to the view that several thrust faults discovered in 1909 and 1910 are really parts of one great fault that may extend for 270 miles with sinuous course from Woodruff, Utah,

\footnotetext{
ischultz, A. R., and Richards, R. W., A geologie reconnaissance in southeastern Idaho: U. S. Geol.
}

Durvey Bull. 530, pp. 207-284, 1913. 
to John Grays Lake and the Blackfoot Range. The minimum horizontal displacement produced by this great fault, based on a structure section constructed across the Montpelier quadrangle, from the southeast corner T. 11 S., R. 43 E., to the northeast corner T. 11 S., R. $45 \mathrm{E}$., normal to the fault trace, is 12 miles. The maximum displacement in the region, based on the shortest distance between 2 line connecting the westernmost known points on the fault trace and a tangent to the east margin of the fault, is 35 miles.

\section{AGE OF THE BAWTOCK OVERTHRUST.}

The oldest rocks involved in the faulting are sandstones of the Beckwith formation, which may in part be of early Cretaceous age. The youngest rocks which have been found concealing its trace are the conglomerate of the Almy formation, ${ }^{1}$ which represents the basal division of the Wasatch group (Eocene) as defined by Veatch.

The possible range of age is, then, from late Cretaceous to early Eocene, and it is probable that the faulting may have occurred during the interval represented by the unconformity between the Adaville $^{2}$ and Evanston ${ }^{3}$ formations of Veatch.

\section{OTHER FAULTS.}

Minor overthrusts are present, some of which are subsidiary branches of the main thrust; others, which may have originated at the same time and from the same general cause, apparently have no direct connection with the major fault.

Normal faults occur within the area but are few in number and so far as known of slight importance.

\section{DETAIIED DESCRIPTION OF AREA.}

\section{TOWNSHIPS EXAMINED.}

The area examined in 1911 comprises eight townships in Rs. 44 and $45 \mathrm{E}$. of the Boise meridian. These townships were included in whole or in part in the phosphate reserves as originally constituted by the withdrawals of December, 1908, and December, 1909 . All the eight townships contained phosphate deposits and the rocks immediately associated with them, both normally above and below, and also other rocks which normally lie well above them in the geologic column but which are now found in discordant relation beneath them. The areas of these rocks were complicated by folding and faulting, so that detailed geologic mapping was essential to the study of the deposits.

\footnotetext{
1 Veatch, A. C., Geography and geology of a portion of southwestern Wyoming: U. S. Geol. Survey Prol. Paper 56, p. 89, 1907.

2 Idem, p. 72.

Idam, p. 76.
} 


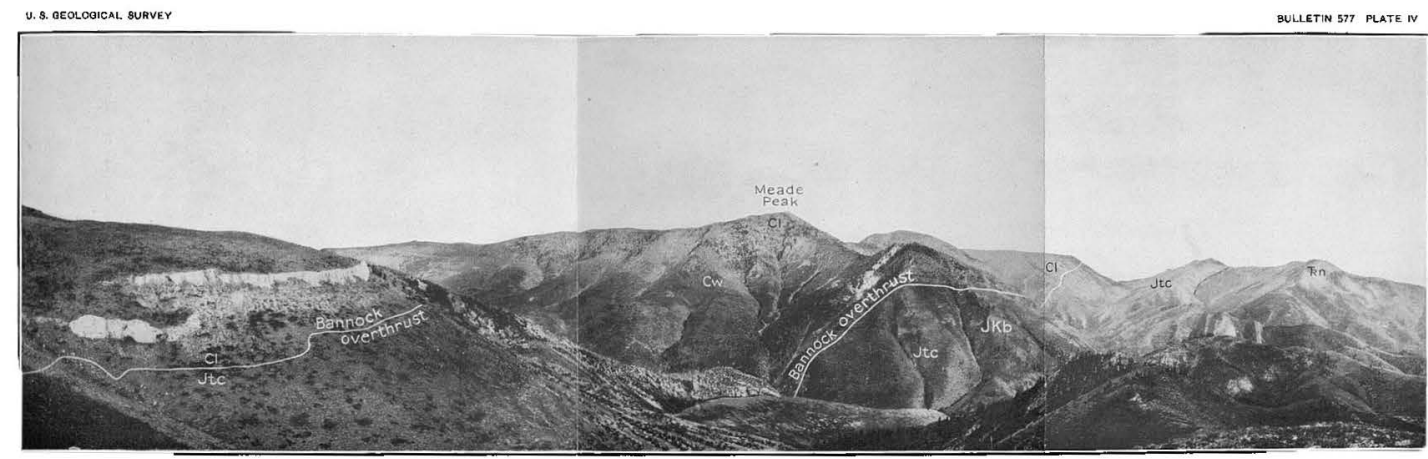

a. PANORAMA FROM SOUTH-POINTING SPUR ON HILL NORTH OF GEORGETOWN CANYON.

Looking northeast to south. Cl, Mississippian limestone: CW. Wells formation; $\mathrm{k} n$, Nugget sandstone; Jtc. Twin Creek limestone; JKb. Beckwith formation.

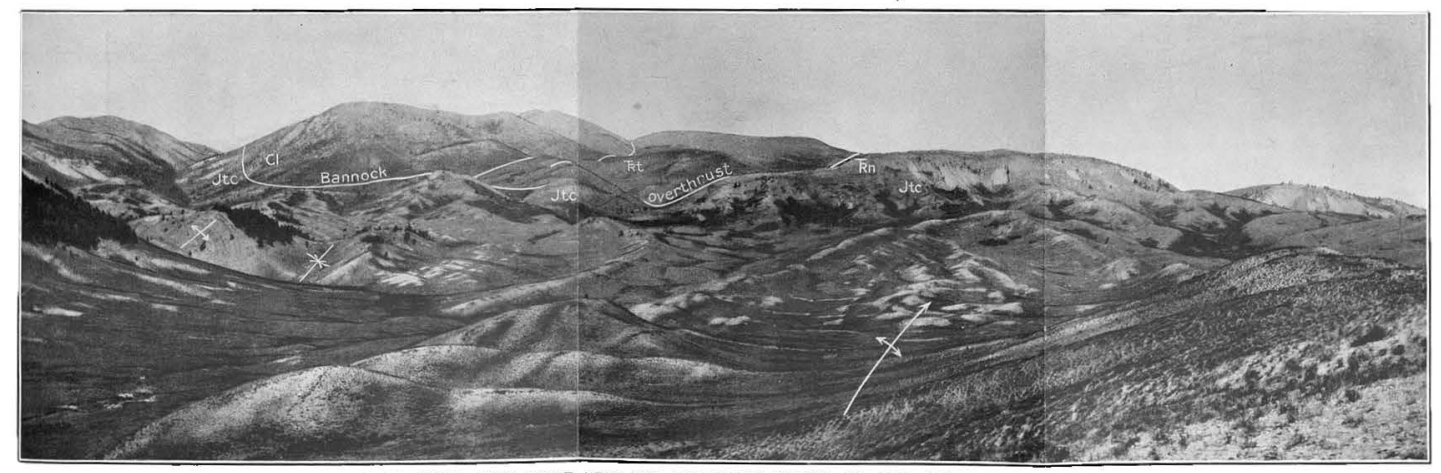

3. PANORAMA FROM POINT NEAR THE SOUTHEAST CORNER OF AREA SHOWN IN PLATE II.

Looking northwest. Showing southern tip of uneroded part of the overthrust block and position of subordinate branch fault. Cl, Mississippian limestone: Ft. Thaynes limestona; Fn, Nugget sand-
stone; Jtc. Twin Creek limestone. Parallel syncline and anticlines in foreground. 
T. 8 S., R. 44 E.

STRATIGRAPHY.

The rocks of T. 8 S., R. 44 E., are all sedimentary and range in age from Carboniferous to Triassic. They comprise the Wells formation, Phosphoria formation (including the Rex chert member), Woodside shale, and Thaynes limestone, which are described in detail on pages 18-31. The alluvial deposits are intentionally omitted, as they generally have no significant bearing on the phosphate deposits.

\section{STRUCTURE.}

The rocks of this township have been folded and faulted on a large scale and the structure is relatively simple. The southwest half is almost entirely occupied by a syncline that enters the area from the township to the south. The west side of this syncline is broken by a fault, interpreted as a thrust with westerly hade, apparently the continuation of the thrust shown in the western part of the township to the south. This fault brings the Rex chert against Pennsylvanian limestones and quartzites in the SW. $\frac{1}{4}$ SE. $\frac{1}{4}$ sec. 31 . From this point it extends to the NW. $\frac{1}{1} \mathrm{NW} . \frac{1}{4}$ sec. 19 , where it appears to die out in the axis of a small anticline. The big syncline is apparently normal and upright and grows narrower toward the northwest. It forms part of a canoe-shaped fold, the northern tip of which lies in the township to the northwest.

East of the above-mentioned syncline is a somewhat narrower anticline, the axis of which lies in the west flank of Dry Ridge. This anticline also appears to be normal and upright, but on account of the absence of upper Mississippian rocks in the axial region of the fold it is presumed that the apparent unusual thickness of the Pennsylvanian strata is due to subordinate folding, and such folds have been represented in sections A-B and C-D on the map (Pl. V).

The northeast part of the township, including Dry Ridge, is occupied by a part of another large syncline that enters this township from the township to the east (Pl. II, B, p. 12). The axis of this syncline probably crosses. sec. 1 near the center, with a northwest trend. From the SE. $\frac{1}{4}$ NE. $\frac{1}{4}$ sec. 25 to the SW. $\frac{1}{4}$ SE. $\frac{1}{4}$ sec. 14 this syncline is bordered by a fault that dies out in sec. 14. The course of this fault through two deeply cut strike or subsequent valleys indicates that its hade is nearly vertical. The effect of the fault is to cut out parts of the Phosphoria formation and in the NE. $\frac{1}{4}$ SW. $\frac{1}{4}$ sec. 24 to cut out this formation entirely.

The great Bannock thrust fault is believed to pass beneath this township but at depths too great to affect the phosphate shales.

The structural relations above described are shown in the sections on the map of the township (Pl. V). 


\section{PHOSPHATE DEPOSITS.}

Previous to the examination by the Survey no prospecting had been done in this township. In 1910 the Survey party, in connection with the examination of the adjacent township on the west, made a shallow opening in the phosphate shales in the SW. $\frac{1}{4}$ SW. $\frac{1}{4}$ sec. 7. The section thus obtained and the analyses of the samples taken were published in the report for $1910,{ }^{1}$ and are reprinted in this paper for the sake of comparison. (See p. 29.) They seem to show an unusually lean portion of the phosphate shales. The phosphate beds are unusually thin and the content of phosphoric acid is unusually low.

In 1911 the Survey party made an opening in the naturally exposed phosphate shales in the SW. $\frac{1}{4}$ SE. $\frac{1}{4}$ sec. 14 . Three pits were opened and offset in such a manner as to cover nearly the entire thickness of the shales. The measurements of the section and the phosphate content of samples are given in the table on page 28 .

The table shows that the thickness of high-grade phosphate rock near the base of the shales is unusually great, amounting to 14 (?) feet, and that another bed of high-grade rock, whose thickness is not definitely known, occurs near the top of the shales, only a few feet below the chert. It may be noted from the map that both the sections referred to are in close proximity to zones of minor folding or faulting. Thus the unusually thin and lean character of the one exposure and the unusually thick and rich character of the other may in some measure be connected with these minor movements. It seems fair, then, to assume that the phosphate deposits do not differ widely in average thickness and character from. those of the neighboring townships, and that an average thickness of 6 feet of workable phosphate may safely be inferred.

The phosphate beds underlie 16,000 acres in this township at a depth probably nowhere greater than about 4,000 feet. The greatest depth occurs in the northeast corner of the township near the center of sec. 1. The dip of the beds varies but is generally not less than $20^{\circ}$, though in some places it is as much as $40^{\circ}$, and in a few localities considerably more. It is doubtless safe to assume an average $\operatorname{dip}$ of $30^{\circ}$.

On the assumption, then, that a 6 -foot bed of phosphate underlies 16,000 acres of land and dips on an average $30^{\circ}$, and that the weight of a cubic foot of high-grade phosphate rock is 180 pounds, there are within this township approximately $386,400,000$ long tons of phosphate. Much of this rock is easily accessible from points of entry in Slug Valley and Dry Valley.

1 Richards, R. W., and Mansfield, G. R., Preliminary report on a portion of the Idaho phosphate reserve: U. S. Geol. Surv̀ey Bull. 470, p. 389, 1911. 

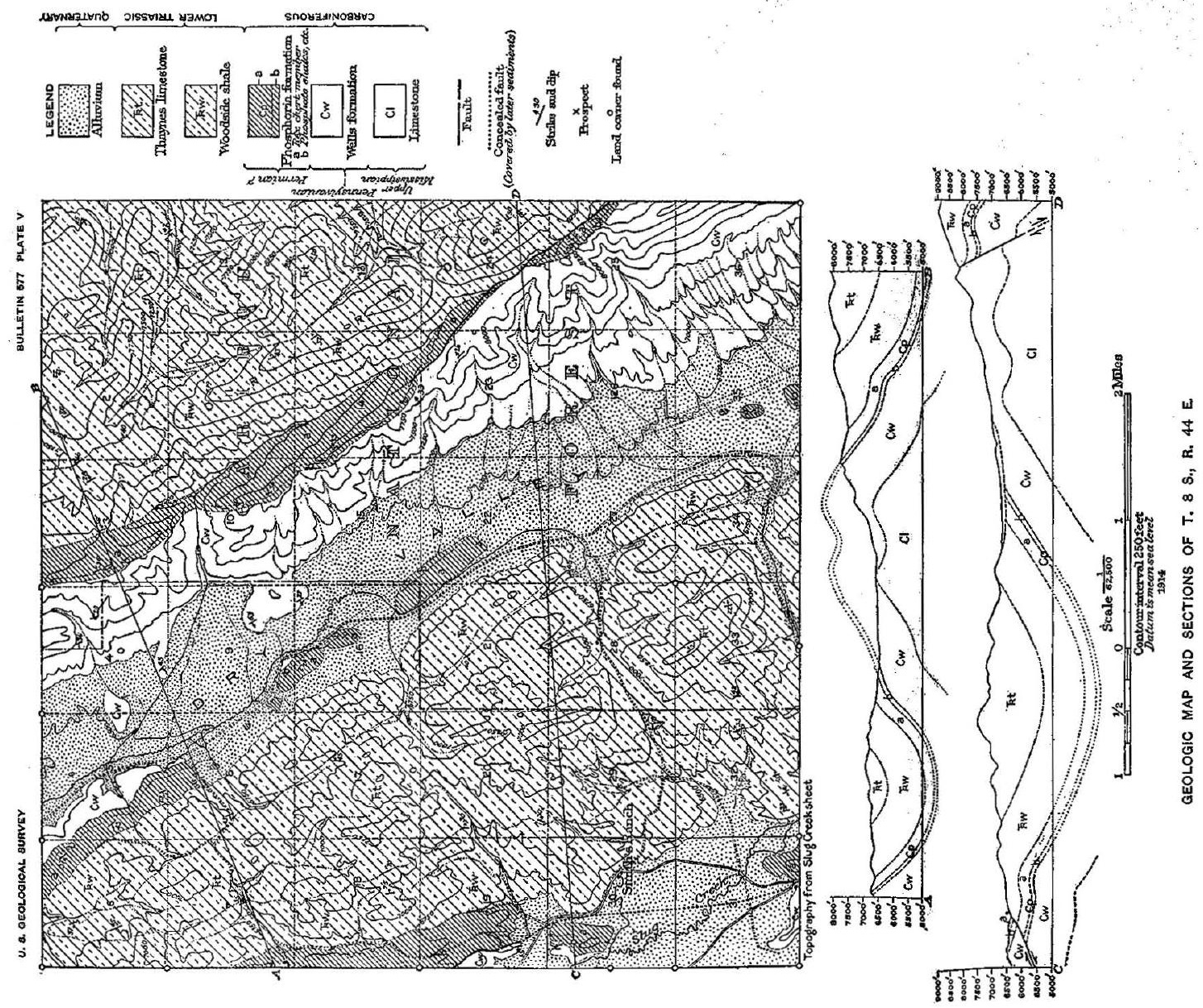

SURVEY.

The detailed geologic examination of T. 9 S., R. 44 E., was made during the early part of July, 1911. A brief inspection of portions of this township was made later in the same season by W. C. Mendenhall, F. B. Van Horn, and A. R. Schultz, of the Survey. The work was done mainly with plane table over the topographic base prepared by Albert Pike during the preceding summer.

The accompanying map (Pl. VI) is a reproduction on a smaller scale of the field map with portions of the original detail omitted.

Only a partial survey of the township has been made by the General Land Office, but a theoretical net has been projected over the remainder of the township for convenience in reference.

\section{STRATIGRAPHY.}

The rocks of this township range in age from Carboniferous to Pliocene or Pleistocene and include both sedimentary and igneous types. The various formations are fully considered on pages 14-33 of this report, but a brief description of them is given here, together with an account of their distribution.

- The Carboniferous rocks include upper Mississippian limestone, the Wells formation (Pennsylvanian), and the Phosphoria formation (Permian ?). The Madison limestone has not been observed. The rocks below the Phosphoria formation were not differentiated in the field, but it is probable that most if not all of them should be assigned to the sandy limestones and quartzites of the Wells formation. They occupy most of the southeastern part of the township and underlie most of secs. 1, 12, 13,30,31, and 32 , and a strip along the west border of the township. The topmost part of the formation, which underlies the phosphate beds (the underlying limestone of the report for 1910), is well developed in many places and forms fine cliffs in seas. 16 and 18.

The Phosphoria formation underlies the valley just east of the ridge that extends from sec. 32 to sec. 19. It also spreads around a lower intervening ridge and appears on the west side of Slug Valley from sec. 28 to sec. 17 . Farther north it appears in a belt extending north from the NE. $\frac{1}{4}$ sec. 7 through sec. 6 . Southeast of the Schmid ranch the formation extends from the NE. $\frac{1}{4}$ sec. 8 obliquely across the broad range east of Slug Valley, through secs. 9, 16, 15, and 14, whereit plunges beneath the alluvium in Dry Valley. It reappears in the eastern half of sec. 2. In the NE. $\frac{1}{4} \mathrm{SW}$. $\frac{1}{1}$ sec. 28 the Rex chert member is horizontal and has a pseudocolumnar jointing resembling basalt (Pl. VII, $B$ ). The lower or phosphate-bearing portion is not exposed but may be iraced by float in characteristic position between 
the underlying limestone and the chert. This portion of the formation finds topographic expression in the line of depressions or saddles that runs parallel to the heavy chert ledges of the upper member of the formation, as is particularly well shown in secs. 32 and 29 . The Rex chert member is marked by heavy chert layers, which locally, as in sec. 2, constitute the entire member and form great ledges. Elsewhere, as in sec. 20, this member is more largely composed of the chippy and flinty shale facies, which weathers into smooth slopes, with few or only subordinate ledges. No fossils were observed in either facies.

The Woodside shale occupies two areas in this township. It forms a belt a quarter to half a mile wide along the east flank of the ridge west of Slug Valley from sec. 21 to sec. 7 . It also underlies the entire range between Slug Valley and Dry Valley in the northern part of the township, including the area north of a line extending northwest from sec. 14 to sec. 5 . In the western belt only the lower half of the formation is exposed-the thin-bedded sandy limestones and yellowish and greenish shales. In the eastern area the entire thickness of the formation is present, and the heavy limestones of the upper portion, some of which are crowded with pelecypod shells, form pronounced ledges on the hilltops.

The Thaynes limestone appears only in a small area, including parts of secs. 2, 3, and 4. The basal member or Meekoceras zone is readily identified and traced, though it is not uniformly developed. The rocks above the base closely resemble the shaly members of the Woodside formation below, so that without the basal member the identification of the formation is difficult. The Thaynes limestone and the limestones of the upper part of the Woodside shale form smooth, high hills, in many places heavily wooded with aspen. Comparatively few ledges are seen. Fine exposures of both rocks are found on the north side of the road in the NW. $\frac{1}{4} \mathrm{SE} . \frac{1}{4}$ sec. 3 . The other Mesozoic formations are not represented in this township.

The Pliocene (?) deposits form a nearly continuous band from a quarter of a mile to a mile or more wide along the west side of Slug Valley, extending from the SE. $\frac{1}{4}$ SE. $\frac{1}{4}$ sec. 7 to the northern part of secs. 33 and 34 . These beds consist of marls, grits, and conglomerates or breccias, which contain fragments of local sedimentary rocks only. They form hill slopes and ridges whose greatest elevations are 250 feet or more above the bottom of Slug Valley. One isolated patch in the NW. $\frac{1}{4} \mathrm{NW} . \frac{1}{4}$ sec. 33 and adjoining portions of sec. 32 lies at an altitude of 7,241 feet or nearly 700 feet above the level of Slug Valley. The beds are not horizontal. The dips range from $18^{\circ}$ to $58^{\circ}$, indicating that the beds have been disturbed by orogenic movements since their deposition, for inclined deposition could not account for dips so great. 

Basalt covers a little more than a square mile in secs. 33 and 34 . The rock is dark, somewhat vesicular, and weathers brown. It has few outcrops and weathers into bowlders ranging from a few inches to 2 or 3 feet in diameter. It appears to overlie the Pliocene (?) beds and is not definitely represented in the conglomerates of those beds. Bowlders of the basalt occur within the area mapped as Pliocene (?) in the NW. $\frac{1}{4} \mathrm{NW}$. 1 sec. 34 , but it is believed that these bowlders have been carried downstream from the basalt hills and do not represent bowlders weathered from the Pliocene (?) deposits. The basalt appears from its relation to the supposed Pliocene marls and conglomerates to be of late Pliocene or early Pleistocene age. The hills that it now caps have shared in the general erosion of the region and have acquired forms comparable to those developed in the neighboring earlier sediments.

\section{STRUCTURE.}

The main structural features of the phosphate deposits in this township are two synclines, more or less broken, that form southern extensions of a larger syncline which occupies the west half of the adjoining township on the north. Between the two synclines an anticline plunges gently northwest and is broken by a fault with downthrow on the west, so that rocks of Lower Triassic age (Woodside shale) are probably brought into contact with lower Pennsylvanian rocks. The fault is concealed beneath the alluvium of Slug Creek, and between the two rock formations lies the band of Pliocene (?) marls, grits, and conglomerates. The absence of these supposed Pliocene beds on what appears to be the upthrown side of the fault, together with the steep dips in these beds already noted, suggests that this fault is associated with a later period of disturbance than that which developed the main structural features of the district. According to this view the Pliocene (?) beds may have been deposited on the east side of Slug Creek as well as on the west, but if so they have been removed by erosion.

The western syncline extends from the north-central part of sec. 4, T. 10 S., R. 44 E., in a northwesterly direction through T. 9 S., R. 44 E., as far as secs. 17 and 18. The west limb is fairly straight. In the SW. $\frac{1}{4}$ SW. $\frac{1}{4}$ sec. 33 the rocks dip about $45^{\circ} \mathrm{E}$., but from the SE. $\frac{1}{4} \mathrm{SE}$. $\frac{1}{4}$ sec. 29 throughout the remainder of this limb the dips are reversed and become westerly, the angles ranging from $22^{\circ}$ to $65^{\circ}$. The syncline as a whole is therefore strongly inclined eastward: The east side of the syncline is partly obscured by basalt and Pliocene (?) deposits, but from the center of sec. 28 northwestward its boundary is marked by a fault that brings the upper part of the Phosphoria formation (upper part of the Rex chert member) against the lower part of the Wells formation. East of this fault 
lies a somewhat irregular area of sandy limestones and quartzites of the Wells formation. The eastern boundary of this area is also formed partly by a fault that seems to be a continuation of the same fault that marks its western boundary. The dips of the rocks lying east and west of this lower Pennsylvanian area, as well as some of the dips within the area itself, indicate a general anticlinal structure.

The interpretation offered for the appearance of this area, made up of the beds of the Wells formation and largely bounded by faults, within the general syncline of the Phosphoria formation has already been given on page 37 .

The eastern border of the area of rocks of the Phosphoria formation in secs. 17, 20, and 21 has been crumpled by minor folds. From the NW. $\frac{1}{4}$ sec. 20 through secs. 17, 18, and 7, and northwestward there is a fault, interpreted as a subsidiary thrust, that brings the Woodsido shale and the Rex chert member of the Phosphoria formation against lower Pennsylvanian sandy limestones and quartzites (Wells formation), with the younger racks on the east (Pl. VII, $A$ ).

The foregoing structural features are shown on the sections drawn along the lines $A-B$ and $C-D$, accompanying the map (PI. VI).

The eastern syncline is apparently normal and upright, though the axis lies nearer the east than the west side. The southeast portion of the syncline is concealed beneath the alluvium of Dry Valley. The limits of the concealed portion have been shown on the map as calculated from the thickness and dips of the formations involved. The structural features of this syncline are indicated in the section drawn along the line $E-F$.

\section{PHOSPHATE DEPOSITS.}

The phosphate beds are not naturally exposed in this township, and previous to the summer of 1911 no openings in the beds had been made. In the NW. $\frac{1}{4}$ NE. $\frac{1}{4}$, sec. 16 the Survey party in July, 1911, opened a trench 450 feet long that had a maximum depth of about 10 feet. This trench traversed the formation from the overlying chert to the underlying limestone (Pl. III, p. 36). The character of the formation as there exposed is given, together with phosphate content of samples of the more important phosphate beds, on pages $27-28$.

The formation in this township contains two important phosphatebearing zones, near the top and the bottom, respectively, with a broad barren zone between. Each of the phosphate-bearing zones consists of several members and includes narrow bands of lean or barren material. The upper zone contains an aggregate of 4 feet 6 inches of phosphate rock averaging 60 per cent or more tricalcium phosphate and an additional band, 1 foot 10 inches thick, averaging nearly 50 


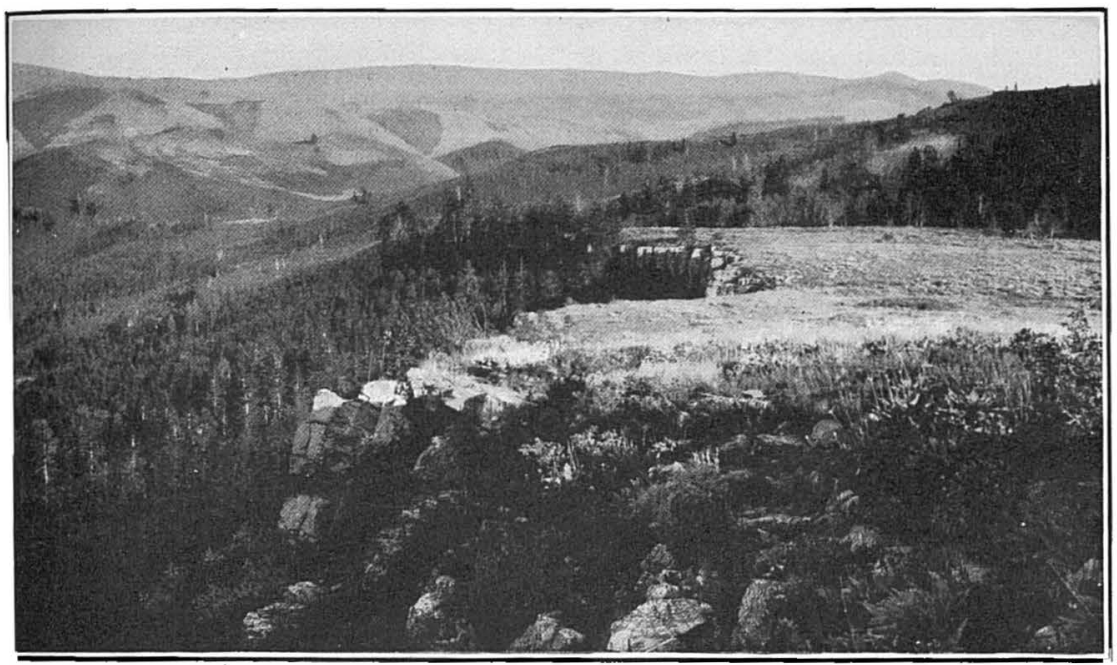

A. CLIFFS OF WELLS FORMATION, WEST SIDE OF SLUG VALLEY, SEC. $18, \mathrm{~T}, 9$ S., R. 44 E.

Down-faulted Triassic rocks on left; Carboniferous rocks in distance. The phosphate shales have been largely eroded from the top of the Welis formation.

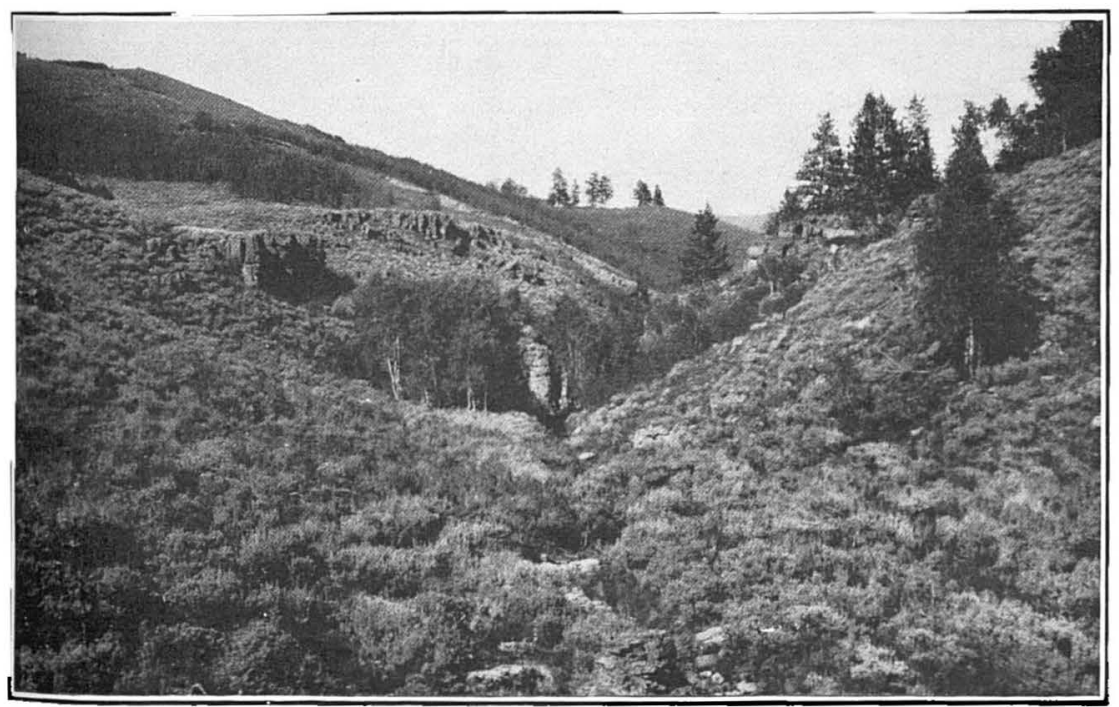

B. LEDGES OF HORIZONTAL BEDS OF THE REX CHERT MEMBER OF THE PHOSPHORIA FORMATION, SEC. 28, T. 9 S, R. 44 E.

Pseudo-basaltic appearance is due to jointing and weathering of the chert. 


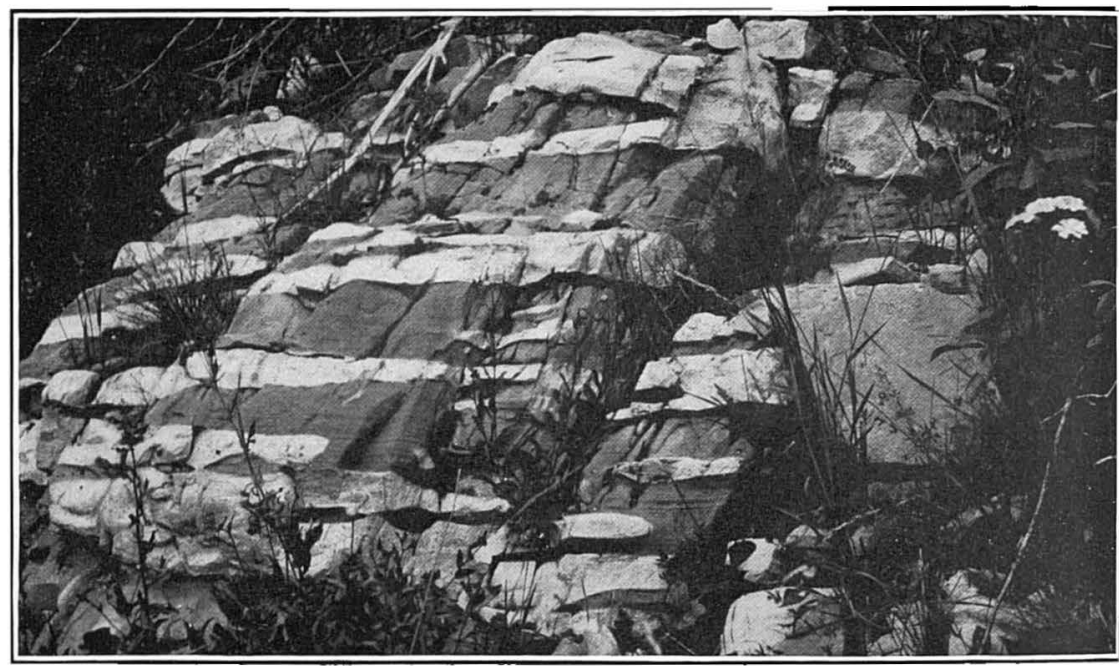

A. WELLS FORMATION, SEC. 5, T, 10 S., R. 44 E.

Showing characteristic interbedding of sandstone and cherty limestone (largely silicified).

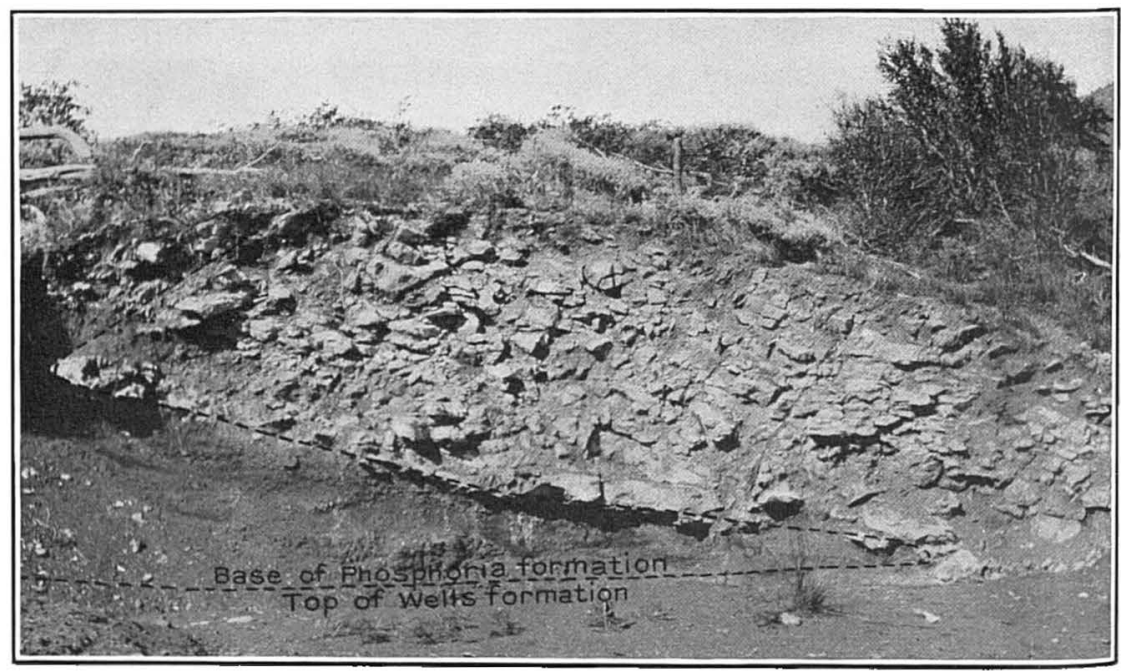

B. DRAG FOLD IN UNDER LIMESTONE AND PHOSPHATE SHALES, IN NW. $\frac{1}{4}$ SW, $\frac{1}{4}$ SEC. $25, T, 10$ S., R, $44 \mathrm{E}$. 
per cent tricalcium phosphate. The lower zone has two beds aggregating 3 feet 5 inches of phosphate rock that averages nearly 60 per cent tricalcium phosphate. The rock from which sample No. 2 was collected lies immediately beneath a broken and contorted zone of phosphate shales and thin limestones. The position of this bed corresponds to that of the main bed in the townships to the west and south. The main bed in Georgetown Canyon is 6 feet 4 inches thick. These facts, together with the general uniformity of thickness of the main bed elsewhere, tend to show that in this section part of the bed has probably been cut out.

The phosphate beds where exposed by trenching were rather deeply overed by weathered surface drift, and the inclination of the beds was such that dirt could be washed into the phosphate rock by percolating waters. It was found impracticable to deepen the ditch sufficiently to secure wholly clean material for analysis, hence it is probable that the given figures are somewhat low. As it is, the trench Bows a total thickness of workable phosphate rock amounting to bout 8 feet, with an average content of about 60 per cent tricalcium. phosphate.

The phosphate beds underlie 10,000 acres in this township, at a depth probably nowhere greater than 1,800 feet. The dip of the beds varies and locally is quite steep, but these steep dips do not in all probability descend to depths greater than 500 or 600 feet. The great bulk of the deposit appears to dip $10^{\circ}$ to $20^{\circ}$, and perhaps $15^{\circ}$ may be triken as a fair average.

If only the upper bed, 4 feet 6 inches thick, is considered, and the dip is taken as $15^{\circ}$, and if the weight of a cubic foot of phosphate rock is taken at 180 pounds, there are within this township, in the upper Ged alone, 164,600,000 long tons in round numbers of phosphate rock averaging 60 per cent or more tricalcium phosphate. If the lower Bed, 3 feet 5 inches thick, is added under the same conditions, the total tonnage will be approximately $289,839,500$ long tons.

The entire region underlain by phosphate rock is believed to be a part of the great thrust block previously referred to (see p. 35), and hence it is perhaps underlain by a great thrust fault. The depth of the supposed fault beneath the surface is not known. It is doubtful if it is high enough in this township to cut out much if any of the phosphate-bearing formation, yet in the absence of definite information such as that given by drill records it is perhaps wiser to make ample allowance for that possibility. Thus the smaller figure given above should fall well within the limits of probability.

Both the eastern and western areas are accessible from valley bottoms and much of the rock is probably above ground-water level. 
T. 10 S., R. 44 E.

SURVEY.

The eastern part of T. 10 S., R. 44 E., was surveyed by Gale in 1909, and discussed in a preliminary report on the Georgetown district. ${ }^{1}$ A topographic map on the scale of $1: 31,680$ was made by Albert Pike in 1910. This was used as the base for the geologic work during the following summer.

\section{STRATIGRAPHY.}

The earlier Carboniferous rocks occupy the greater portion of the township, but in the south-central part a somewhat triangular area of Jurassic limestone and sandstone underlies limestones of Carboniferous age, older than the phosphate rocks.

The phosphate deposits have been so folded in the synclines as to present a full section of the Woodside shale, and locally the basal portions of the Thaynes limestone are also exposed. Tertiary marls and conglomerates cover a considerable area in the southwestern corner of the township and are also present in minor patches to the north.

Igneous rocks are represented by a small area of cellular basalt in secs. 3 and 4 .

\section{STRUCTURE.}

Two independent structural complexes exist in this township. These two units bear an abnormal stratigraphic relation to each other in that the overlying unit is made up in general of the older rocks. This abnormal relation is a result of the Bannock overthrust, which has been referred to on page 35 . The area of Jurassic rocks in the south-central part of the township is a portion of the underlying block which has been uncovered by erosion. The surface or plane of the Bannock thrust was probably originally nearly horizontal, but it has been subsequently deformed and in this township shows welldeveloped folds.

The structure of the superimposed block comprises a series of anticlinal and synclinal folds whose axes have a trend slightly east of north. The structural details are not clear west of the high ridge in the eastern part of the township, as the distribution of the several formations older than the phosphate rocks has not been mapped. This ridge, however, is known to be roughly paralleled by a strike fault whose trace swings locally from one side to the other of the ridge.

The structure of the underlying block is characterized by the presence of somewhat broader folds than those of the upper block, and the axes apparently have a nearly parallel trend. 


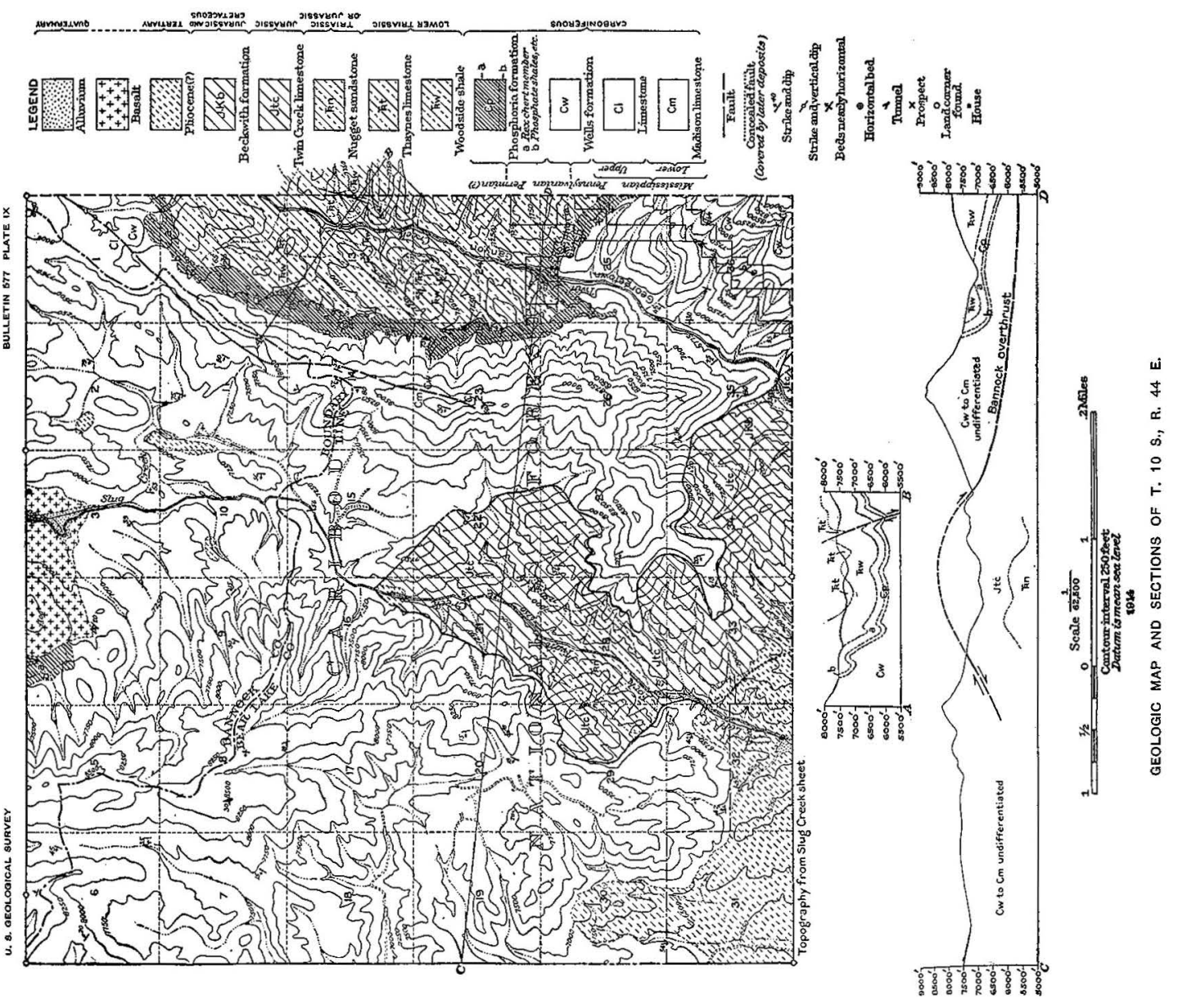



PHOSPHATE DEPOSITS.

\section{GEMERAI FEATURES.}

The phosphate deposits lie in a synclinal trough which is situated mainly in secs. 12,13 , and 24 . The fold is modified slightly by the presence of minor folds (Pl. VIII, $B$ ) and at least one fault. The southern tip of another phosphate-bearing area enters the township in sec. 4. The phosphate shales here, as elsewhere in this general region, are inclosed between an underlying light-colored sandy limestone and an overlying dark-colored chert, which in nearly all attitudes makes salient topographic features.

The main phosphate area forms a rather lenticular patch, about 3 miles long and 1 mile wide, in the eastern tier of sections. In a graphic projection it would appear like the somewhat distorted bow of a canoe. In reality it constitutes only the southern tip of a long boatlike fold, which extends far to the north, as will be seen by reference to the general map (fig. 2, p. 15). The margin of this area is crenulated by subordinate folds.

The other phosphate areas are much smaller but have a similar structure and shape.

In most places the outcrop is best marked by prominent ledgesupported ridges of the overlying chert, but in other places the underlying limestone makes either a well-defined cliff, a salient knoll, or a ridge. The shales are more easily eroded and are generally characterized by the development along them of minor gullies, many of which are too small to be shown on the field scale of mapping.

\section{QUALITY OF PHOSPHATE ROCK.}

Many shallow openings have been made along the outcrop of the phosphate shales in the course of the assessment and patent work incidental to the mineral claims of the Utah Fertilizer \& Chemical Manufacturing Co. At the time of examination by the United States Geological Survey, however, nearly all the sections had been obscured by caving, and information was chiefly gained from the more extensive cuts in the township to the east. A better-exposed section is described on pages 24-25, and another, which supplements it somewhat, on pages 25-26. A prospect in the NE. $\frac{1}{4} \mathrm{SE}$. $\frac{1}{4}$ sec. 25 showed a section of the main bed measuring 6 feet 6 inches, and a sample collected here contained 37 per cent phosphoric acid, equivalent to 80.8 per cent tricalcium phosphate. The outcrop of the shale contains abundant pieces of high-grade phosphate rock, and similar pieces are also found on the dumps of many of the caved openings. The field evidence appears to indicate that this area contains rock which will run 70 per cent or over in tricalcium phosphate, probably in beds comparable in thickness to those of the section given on pages 24-25. 
AREA AND TONHAGE.

The main phosphate area comprises about 1,920 acres and the minor tracts contain about 80 acres. The area of the main phosphate bed under these lands is greater than their surface area because of the folding, which is indicated in the structure sections $A-B$ and $C-D$ on Plate IX. This folding is estimated to add 25 per cent to the area and thus the main lower bed is estimated to occupy about 2,500 acres. The bed is assumed to average 6 feet in thickness throughout this extent. The content of such a bed of phosphate rock weighing 180 pounds to the cubic foot is $52,000,000$ long tons.

\section{DEVELOPMENT.}

Little has been accomplished in the actual development of this area. Two tunnels, both of which have a southeasterly trend, have been put in by the Utah Fertilizer \& Chemical Manufacturing $\mathrm{C}$. on the Superior Extension claim. One of the tunnels is about 125 feet long, but the other is less than 30 feet. The longer tunnel terminates in the limestone which underlies the phosphate shales. The shorter one is in low-grade shales. A third tunnel about 50 feet in length on the Highland No. 2 claim shows mainly low-grade shales with a minor amount of high-grade rock. The direction of all these workings has been determined by minor folds, which complicate the laying out of a general plan of mining development for the district.

The plan selected will undoubtedly depend mainly on the desired rate of production. If the production is to be moderate, an advantageous procedure for immediate utilization will be to extend the lowest of the present tunnels along the general strike of the main phosphate bed as an outlet for the overhead tonnage. If, however, the demand is large, and a long-lived plan of operations is to be outlined, the economic possibilities of a main tunnel on the principal phosphate bed along the anticlinal crest, with workings inclined toward the west and the east, should be compared with the cost of a series of similarly located surface installations operating by means of inclines from the canyon level. In either system of operations the working tunnels will lie along the synclinal troughs, and the mining practice adopted will involve either a chamber, a caving long wall, or overhead stoping, as the inclination of the phosphate bed and the character of the roof makes advisable.

\section{OWNERSHIP.}

The phosphate lands in this township belong in part to the United States Government and in part to the Utah Fertilizer \& Chemical Manufacturing Co. The company has claims amounting to about 250 acres on the lands described under this township which have been 
surreyed for patent, and it also holds additional areas amounting to about 480 acres. The remaining area, about 1,190 acres, is public land; all within the Caribou National Forest.

ACOESSIRILITY.

Georgetown Canyon offers a natural outlet for the phosphate rock in this township. It is reported that a location survey for a spur to connect with the Oregon Short Line Railroad has been made, but there appears to be little probability that this line will be constructed in the near future.

\section{T. 11 S., R. 44 玉.}

SURVEY.

The detriled geologic survey of T. 11 S., R. 44 E., was made in June, 1911, the topographic base being obtained by the enlargement of the corresponding portion of the map of the Montpelier quadrangle, Which was made by A. E. Murlin and Albert Pike in 1909. The general geologic survey of the township was made on scale of $1: 31,680$, but a small area of especially complicated geologic structure which contains phosphate was mapped on a larger scale.

\section{STRATIGRAPHY.}

The rocks of the Phosphoria formation with the included phosphate deposits are found only in the northeast corner of the township. The formations that outcrop in the remainder of the township are the Beckwith formation, the Twin Creek limestone, the Nugget 8andstone, the upper Mississippian limestone, the Tertiary lake beds (presumably Pliocene), and the alluvial deposits of the portion of Bear River valley included in the southwestern part of the township. The lake beds and the alluvial deposits conceal the geology of the older rocks, so that little can be inferred concerning the presence or absence of phosphate in the areas covered by them.

\section{STRUCTURE.}

The presence of phosphate in secs. 1 and 12 is due solely to the geologic structure, as the area that includes the Permian (?) and Thiassic rocks has been thrown out of ordinary sequence and lies above rocks of much later age. The great thrust fault which has acomplished this result is described, together with its general effects, on pages 35-38. The local effect of this fault is to place upper Mississippian limestone over Jurassic limestone. The plane of the thrust in this township is nowhere exposed in horizontal position but dips steeply both east and west, subseruent deformation having been marked.

$37002^{\circ}-14-4$ 
The structure of the underlying block, or the base on which the thrust rests, consists of broad anticlinal and synclinal folds involving rocks of at least Triassic and Jurassic ages. The adjacent structure to the west is concealed by the Tertiary beds and the alluvium. A strong suggestion of recent fault movement along the eastern margin of the valley was noted and the position of the fault plane is indicated in secs. 16 and 21 on the map (Pl. X).

The structure of the overlying block, which comprises beds ranging in age from upper Mississippian to Triassic, is complicated both by close folding and by subordinate faulting. The synclinal folds which hold the phosphate deposits are truncated by these faults. The attitude of the faults is by no means simple but is so variable that it must doubtless be due in greater part to warping or folding.

\section{PHOSPHATE DEPOSITS.}

The phosphate deposits of the township form two distinct areas, the larger of which, situated in South Canyon, will be first described, and the smaller, described by Gale and Richards ${ }^{1}$ in 1910, which lies on the western slope of Meade Peak, will afterward be reviewed briefly.

SOUTH CANYON DISTRICT.

GENERAL FEATURES.

The topographic features of this district are shown in Plate I (p. 10).

The prominent natural exposures of the dark-colored phosphate shales in the gulch on the south side of South Canyon near the present mine openings led to the original discovery, but the strong outcrop of the persistent overlying Rex chert member of the Phosphoria formation is a more useful marker of the geologic horizon. The underlying limestone is present but is not prominent enough to serve as a marker. The phosphate deposits outcrop in two places in South Canyon, one of which lies in the township under discussion and one just east of the township line. The western outcrop has been known for some time and upon it the local prospecting has centered. The eastern outerop was apparently unknown prior to the examination by the United States Geological Survey. It will be considered briefly here because of its bearing on the deposit in sec. 12. The eastern outcrop is marked by an equally prominent ledge of the Rex chert. Float phosphate rock was also found in considerable abundance along the trace of this outcrop. The rocks in the area between the western and eastern chert ledges, although poorly exposed, clearly consist of the iron-stained calcareous shales of the Woodside shale. 

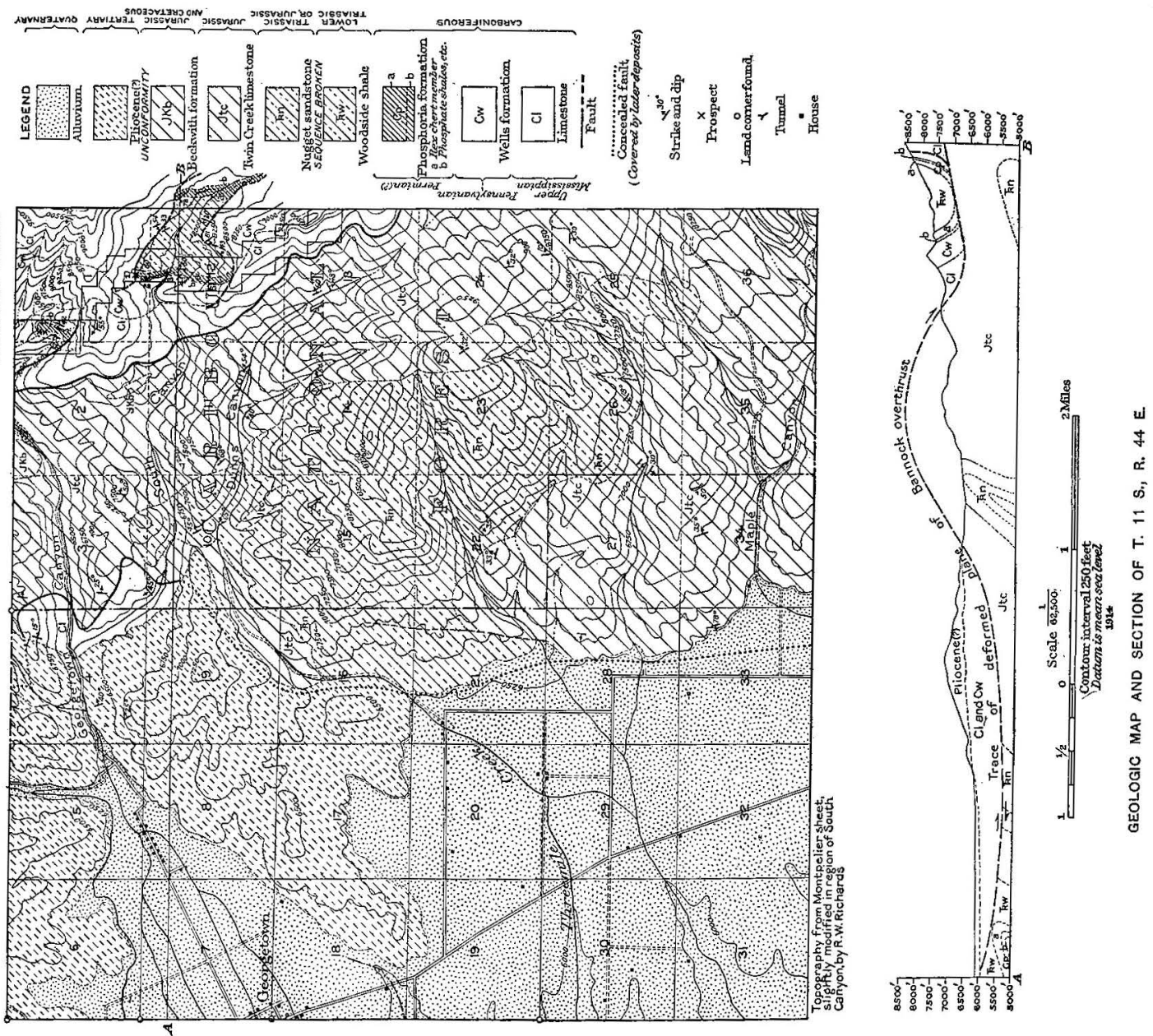

The shape of the deposit is revealed on the east and west by the distribution of the outcrops of the phosphate shales and on the north and south by the presence of areas of rocks older than those containing the phosphate (Mississippian limestone and Wells formation), which have presumably come into their present relation to the phosphate and the overlying rocks by faulting. The exact position of the fault planes is known in only a few places because of the scarcity of ledges and their irregular distribution. This much, however, appears clear, namely, that the faults are overthrusts whose planes have been subsequently folded. These faults are doubtless closely related to the Bannock overthrust (Pl. I, p. 10).

The areal distribution of the several formations together with the inclination of the chert ledges leads to the conclusion that the phosphate deposits lie in a synclinal basin which comprises a portion of the overthrust block. A diagrammatic cross section of this basin is included in the structure section on Plate X. Future mining development will probably demonstrate that the fold is complex rather than simple, as represented, and that it comprises a number of smaller folds.

CHARACTER OF PHOSPHATE ROCK.

A number of prospect openings have been made on the phosphate shales by the Utah Fertilizer \& Chemical Manufacturing Co. These were somewhat caved when examined by the members of the Survey party, so that the information obtained is incamplete. The principal exposures are described in the order of the numbers which have been assigned to them on the map (PI. X).

Near locality 1 , in sec. 1, within a few feet of ledges of Mississippian limestone; two pits were found. One of them exposed about 3 feet of the basal or main phosphate bed immediately above the underlying limestone. The rock appeared on visual examination to be of excellent quality, and no samples were taken for analysis. The second pit is several feet higher in the shales of the Phosphoria formation, and exposed 2 feet of limestone underlain by about 10 feet of brown phosphatic shales containing a few 2 or 3 inch streaks of higher-grade oolitic rock about 3 feet from the base of the exposed section.

At locality 2 (a prospect) the following section was measured:

Section of phosphate bed in the SE. TSW. 1 sec. 1 (unsurveyed), T. 11 S., R. 44 E. of the Boise meridian, Idaho.

\begin{tabular}{|c|c|c|c|c|}
\hline $\begin{array}{c}\text { Field } \\
\text { No. of } \\
\text { sample. }\end{array}$ & . & $\mathrm{P}_{2} \mathrm{O}_{5}$ & $\mathrm{Ca}_{3}\left(\mathrm{PO}_{4}\right)_{2}$ & $\begin{array}{c}\text { Thick- } \\
\text { ness. }\end{array}$ \\
\hline II 70-1 & 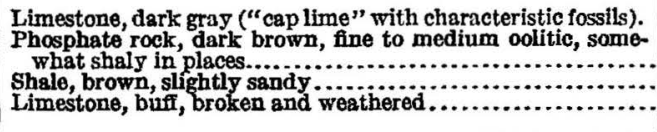 & $\begin{array}{r}\text { Per cent. } \\
33.4\end{array}$ & $\begin{array}{r}\text { Per cent. } \\
72.9 \\
0\end{array}$ & $\begin{array}{rr}\text { Ft. } & \text { in. } \\
4 & 0 \\
2 & 8 \\
-3 & 0\end{array}$ \\
\hline
\end{tabular}


The presence of the "cap lime" as well as the basal position of the bed makes fairly certain the correlation of this bed with that which has been developed rather extensively in the Montpelier district and described by Gale and Richards. ${ }^{1}$

The broken condition of the "cap lime" together with the unusual thinness of the phosphate bed makes it doubful if the entire bed is present at this locality.

The tunnel prospect at locality 3 on the north side of South Canyon shows a section of about 4 feet of medium oolitic brown rock. The local structure is complicated, so that about 50 feet from the entrance the underlying limestone is encountered, and the tunnel makes a sharp bend at nearly right angles to the right for about 30 feet. It then resumes its original trend, about N. $23^{\circ} \mathrm{W}$. At the time of the examination the tunnel terminated about 30 feet from the last turn. The geologic structure, which is roughly followed by the tunnel, may bear two interpretations. It may be either a slight fault or a sharp drag fold (Pl. VIII, $B$, p. 45). The latter view seems to better satisfy the conditions observed.

The rocks cut by the tunnel at the offset and beyond are so finely broken and slickensided that the oolitic texture has largely disappeared from the phosphate rock. A sample of this material tested qualitatively contains a high percentage of phosphoric acid, but no quantitative examination has been made because of the lack of definite information concerning the thickness of the bed.

Another tunnel, locality 4, has been opened on the south side of the canyon, and this affords the best information obtained concerning the main bed in this district. The entrance of the tunnel is located in the phosphate shales, and the tunnel extends westerly across the strike about 30 feet until it cuts the basal phosphate bed and terminates on the underlying brown shale. From this point a drift extends southerly along the strike for about 30 feet. The bed ranges from 5 feet 4 inches to 5 feet 10 inches in thickness. The following section was measured in the face of the drift:

Section of phosphate bed from tunnel of Utah Fertilizer \& Chemical Manufacturing Co., in sec. 12, T. 11 S., R. 44 E. of the Boise meridian, Idaho.

\begin{tabular}{|c|c|c|c|c|}
\hline $\begin{array}{c}\text { Field } \\
\text { No. of } \\
\text { sample. }\end{array}$ & & $\mathrm{P}_{2} \mathrm{O}_{5}$ & $\mathrm{Ca}_{3}\left(\mathrm{PO}_{4}\right)_{2}$ & $\begin{array}{l}\text { Thick- } \\
\text { ness. }\end{array}$ \\
\hline \multirow[t]{2}{*}{$\begin{array}{ll}R & 117-1 \\
R & 117-2 \\
R & 117-3 \\
R & 117-4\end{array}$} & 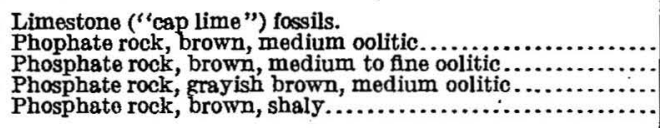 & \multirow[t]{2}{*}{$\begin{array}{r}\text { Per cent. } \\
32.1 \\
34.8 \\
a 35.8 \\
32.1\end{array}$} & \multirow[t]{2}{*}{\begin{tabular}{r|} 
Per cent. \\
70.1 \\
76.0 \\
78.2 \\
70.1
\end{tabular}} & $\begin{array}{rr}F i . & \text { in. } \\
2 & 0 \\
2 & 0 \\
1 & ? \\
& 3 \\
\end{array}$ \\
\hline & & & & $\begin{array}{ll}5 & 10\end{array}$ \\
\hline
\end{tabular}

a The phosphate content of $\mathrm{R}$ 117-3 has been lowered slightly by the inclusion of the underlying shaly bench.

1 U. S. Geol. Survey Bull. 430, pp. 457-535, 1910. 
The average phosphoric acid content for the full section is about 34.5 per cent phosphoric acid, which is equivalent theoretically to 75.1 tricalcium phosphate.

The following excellent natural exposure of the upper portion of the phosphate shale was measured in the gulch south of the tunnel:

Section of the upper portion of phosphatic shales in sec. 12, T. 11 S., R. 44 E.

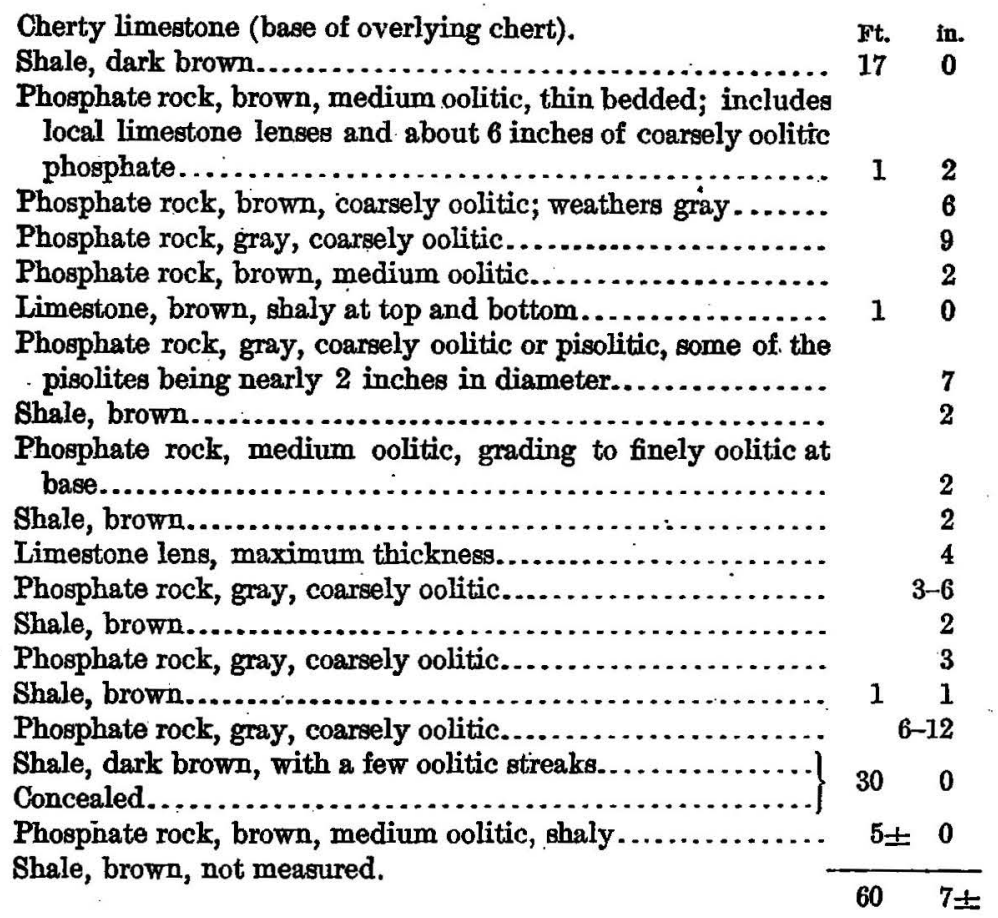

About one-sixth of the section is composed of phosphate rock which contains more than 32 per cent phosphoric acid, or about 70 per cent of tricalcium phosphate. The shale which practically comprises the remainder, by comparison with similar shales which have been analyzed, is estimated to contain about 25 per cent of phosphoric acid, equivalent to 54 per cent bone phosphate. The average content of the 60 feet measured (eliminating the limestone lenses and lentils) would be about 57 per cent tricalcium phosphate. Such material as this, although ündoubtedly of too low grade to be utilized by present practice of superphosphate manufacture, ought eventually to be of value as a source of finely ground phosphate rock meal or "floats," or possibly it could be utilized in some cement-manufacturing process with recovery of the phosphoric acid as a by-product.

About 750 feet south of the natural exposure and some 200 feet higher, at locality 5 , two short tunnels were visited. The more eastorly is shown on the map and is located in the phosphate shales, but 
was so filled by caving that it was inaccessible. The other tunnel is about 100 feet to the west in a siliceous, somewhat porous limestone, lower in the Pennsylvanian portion of the section than the "under lime." Abundant specimens of banded travertine were seen, which is probably to be interpreted as evidence of faulting.

The mapping of the phosphate shales from this point south to the ridge top, where they disappear under Mississippian limestone, is based mainly on the tracing of the accompanying overlying chert to that point by means of abundant float fragments.

AREA AND TONNAGE.

The area of phosphate land in this district can not be regarded as coextensive with the area of outcrop of the normally overlying chert and Woodside shale, because the surface or plane of the Bannock thrust underlies the area and truncates the synclinal fold, somewhat as indicated in the diagrammatic cross section shown on Plate $X$. This plane is estimated to cut the phosphate shales about 1,200 feet down the dip from the level of the tunnels near the canyon bottom. The length of the outcrop from the trace of the fault termination on the north side to that on the south side is about 3,500 feet. The best exposure of the main phosphate bed indicates that it is somewhat over 5 feet in thickness. However, that figure may be taken as the basis for a conservative estimate of its contents.

The total tonnage of the basal phosphate bed included within the three faults and the surface is estimated on the basis noted above at about 1,968,000 long tons of high-grade phosphate rock. The portion of this tonnage lying about the present tunnel (No. 4) level and the south limit of the deposit is 37,000 long tons.

The complete section contains more high-grade rock than is taken for the basis of the calculation, but the data at hand do not warrant more accurate estimates. If the fault plane lies in a position different from the one considered in the estimate, the actual tonnage will decrease or increase as the fault plane rises higher into or falls below the curve described by the phosphate bed in the fold.

PROPOSED DEVELOPMENT.

The Utah Fertilizer \& Chemical Manufacturing Co. plan early development of these deposits. A start was made in the fall of 1911, but the work was interrupted by the heavy snowfall. The company is said to contemplate the erection of surface equipment capable of handling 1,000 tons or more a month, and it is probable that the high-grade rock lying about the present tunnel, No. 4, will be the first removed. Slight difficulty should be encountered in carrying out this plan, although several minor faults offset the phosphate bed toward the west for distances ranging from a few feet to a maximum 
of perhaps 150 feet. The first fault of this series will be cut at about 490 feet from the present tunnel.

The heavy snowfall and avalanches in the vicinity of these openings will make operations during the winter rather expensive and possibly somewhat dangerous. This difficulty would be obviated and at the same time a larger portion of the body of phosphate rock wpuld be made easily minable, by a horizontal tunnel about 5,000 feet in length from about the 6,900-foot level eastward along the line of the geologic section. In offering this suggestion, however, it is not intended to imply that details of costs of construction under this and other plans have been estimated. The total quantity of rock which could be removed through such a tunnel can not be safely estimated at over 196,800 long tons.

OWNERSEIP.

The boundaries of the Great Producer and Great Deposit claims, held by the Utah Fertilizer \& Chemical Manufacturing Co., are shown on the accompanying map (Pl. X). It will be noted that. owing to the peculiar structure these claims contain practically all of the phosphate rock included in the part of this district lying in T. 11 S., R. 44 E.

MEADE PEAT DISTRICT.

The northwestern slopes of Meade Peak consist of rocks older than the phosphate-bearing rocks except in a small tract comprising about 6 acres in the NW. 1 sec. 1 . In this tract the phosphate shales are bent into a sharp syncline which is apparently overturned toward the southeast. This structure is truncated on the south by a fault which is regarded by the writers as a thrust of subordinate order but which is probably a branch of the major thrust.

QUALTTY OF THE PHOSPHATE ROCK.

The lower main bed was sampled in 1909 at the breast of the main tunnel on the claim at this locality. The thickness of the bed at this point is 6 feet and the samples were found to contain 35.7 per cent phosphoric acid, which is equivalent to 78 per cent bone phosphate.

AREA AND TONNAGE.

The area of the outcrop of the phosphate shales, as above noted, is about 6 acres, but the surface area of the phosphate bed is probably at least one-third in excess of this, owing to the compression of the bed in a rather sharp fold. The assumption that a single 6-foot bed of phosphate underlies an area equivalent to 10 acres of flat-lying beds gives about 200,000 long tons of phosphate rock for the main bed. The higher beds in this area in all probability do not carry a sufficient quantity of phosphate to be considered in the tonnage estimate. 
DEVELOPMENT.

The company which preceded the Utah Fertilizer \& Chemical Manufacturing Co. in the ownership of this claim began the development. Near the northeast corner of the deposit a tunnel about 90 feet in length runs in about 60 feet S. $70^{\circ} \mathrm{W}$. and then turns southward, following the bedding or the strike for about 30 feet more. A more favorable location for this tunnel would have been 150 feet lower and about 400 feet slightly west of north of the present location. The suggested location is on the axis of the syncline and at the lowest point on the phosphate bed, and would therefore serve in mining out both limbs of the fold.

A tramway about 3,000 feet in length was built from the elbow of Georgetown Canyon to this phosphate area. The upper end of the tramway is about 1,000 feet above its lower terminal, but it has not been completed.

T. 8 S., R. 45 E.

SURVEY.

The examination of T. 8 S., R. 45 E., was made by the writers during the field season of 1911, after the mapping of the topography by Albert Pike. The township has not been surveyed by the General Land Office, but a theoretic land net has been added to the accompanying map (Pl. XI) for convenience in reference. The area is included in the Caribou National Forest.

STRATIGRAPHY.

The rocks in this township range in age from Pennsylvanian to Lower Triassic. Quaternary alluvial deposits are also present. The older formations are the Wells formation, the Phosphoria formation (including at the top the Rex chert member), the Woodside shale, and the Thaynes limestone.

STRUCTURE.

The geologic structure, as interpreted from the data furnished by the outcropping formations, is fairly simple, the principal features being two synclines separated by a narrower anticline. The axes of the folds have a slightly curving trend and pitch gently about N. $25^{\circ}$ W. This structure is represented graphically in the diagrammatic cross sections on Plate XI. A study of the surrounding region, bowever, makes it clear that this simple structure does not extend to great depths, but that it is interrupted by the Bannock overthrust (pp. 35-38), the plane or surface of which was originally almost horizontal, though now considerably deformed. Below this fault 

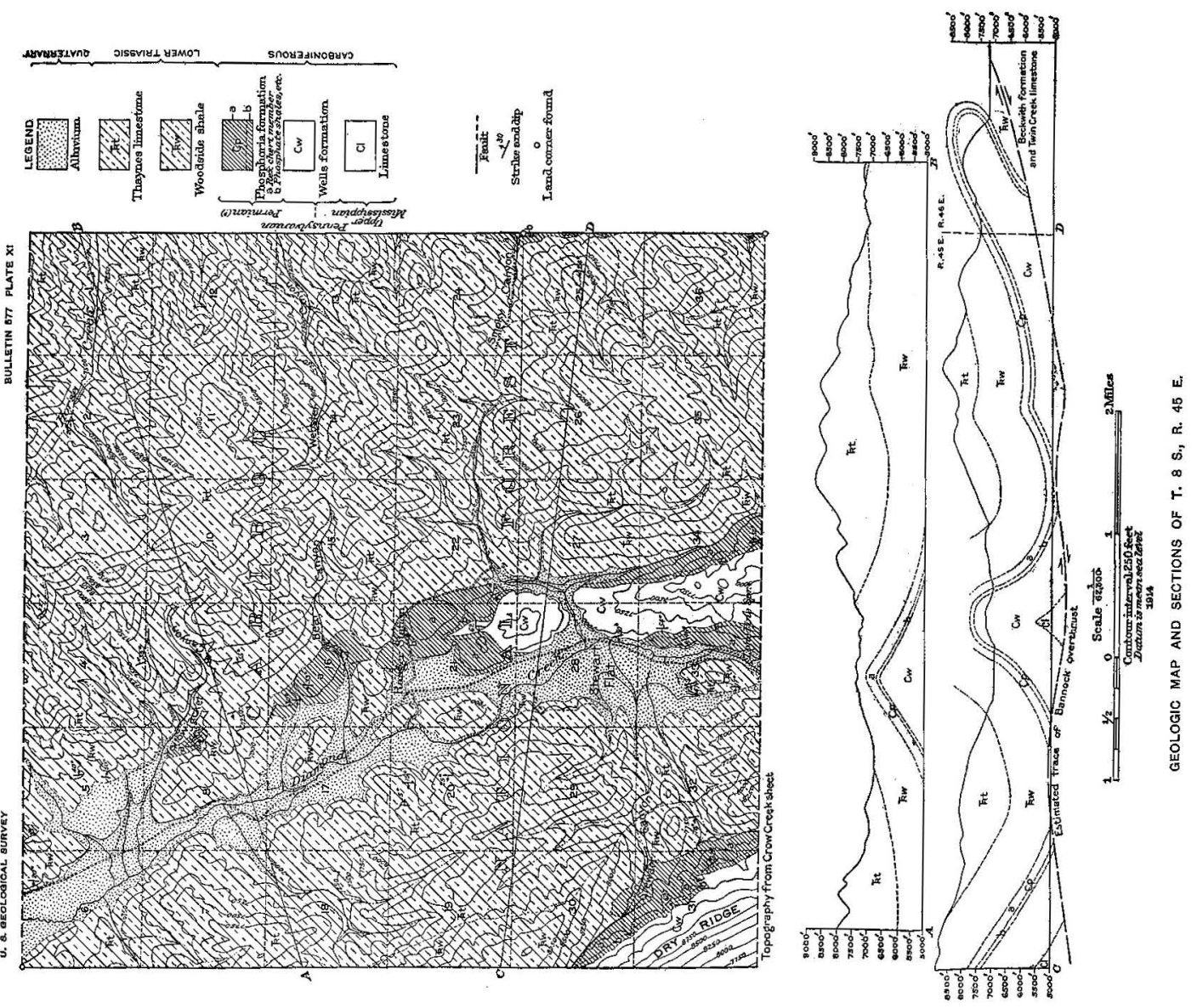

surface, whose depth is mainly a matter of conjecture, the geologic structure differs from that above, and the rock formations in general are of later geologic age.

The principal economic interest in the overthrust involves the question whether or not the bottoms of the phosphate-bearing synclines are truncated by it. The writers are of the opinion that undoubtedly these synclines are cut by the overthrust in some places. It is impossible, however, to verify this opinion without drilling.

\section{PHOSPHATE DEPOSITS.}

\section{OCCURRENCE.}

All the township except about 2 square miles is underlain by phosphate rock, all of which is regarded as ultimately recoverable from favorable points of entry. The phosphate here as elsewhere in this general region occurs in rocks of Permian (?) age and is overlain by dark resistant cherts, which are succeeded by 4,000 to 5,000 feet of limestones, in part shaly, of Lower Triassic age. The whole series of rock, including the underlying sandy limestones, sandstones, and limestones, has been bent up into large folds. The phosphate shales outcrop along the sides and around the tips of the anticlines. The area is unique in that it contains the largest body of phosphate rock included in any township yet examined.

\section{QUALITY OF ROOK AND TONATAGE.}

No prospecting has been done on the phosphate deposits of this township and the nearest section from which information is available concerning the thickness of the phosphate beds and the quality of the rock is exposed in a trench made by the survey party in sec. 14, T. 8 S.; R. 44 E. This section is given on page 28 of this bulletin, and from it the writers consider that the phosphate shales in this township can be reasonably estimated to contain at least a 6-foot bed of rock which averages 32 per cent phosphoric acid, equivalent to about 70 per cent tricalcium phosphate.

The area of lands made up of the rocks of the formations which normally overlie the phosphate in this township is estimated at 21,900 acres.

In estimating the tonnage of the main phosphate bed two factors have to be considered-the increase of area due to folding and also a possible decrease due to the removal of phosphate by truncation of the synclines by the thrust fault. The increase can be approximated with a fair approach to accuracy, but the decrease, quantitatively at least, is so purely a matter of conjecture that it is practically useless to introduce it, although it must diminish the actual tonnage of phos- 
phate to some extent. Theoretically, perhaps, the two factors may be regarded as equivalent, although when actually determined they may be found to vary widely. The assumption that 21,900 acres is underlain by a horizontal 6-foot bed of phosphate rock weighing 180 pounds to the cubic foot gives a total of 459,900,000 long tons.

The depth of the main phosphate bed in the township ranges from the outcrop at the surface to a maximum probably not much in excess of 2,000 feet from favorable points of entry.

DEVELOPMENT.

The phosphate deposits of this township were entirely unprospected prior to this investigation. Their economic development will of necessity depend on the construction of railroads into this district. The natural lines to be followed in the development of the phosphate will be along Diamond Creek to the northwest or (if a railroad is built in Star Valley) along the southern forks of Stump Creek, Smoky Canyon, and the unnamed canyon in sec. 31 , T. 8 S., R. 46 E.

The points of entry which are regarded as most favorable are situated in sec. 21 , T. 8 S., R. 45 E., and in sec. 19, T. 8 S., R. 46 E., on the tips of the anticlines. These points of entry permit the construction of main haulage tunnels northwestward along the anticlinal crests. A system of lateral inclines at favorable grades, connecting the main working tunnels along the synclinal troughs, appears to offer ideal facilities for large-scale extraction of the rock phosphate.

T. 9 S., R. 45 E.

SURVEY.

The geologic examination of T. 9 S., R. 45 E., was made by the writers immediately after the completion of the topographic map by Albert Pike. The township has not been surveyed by the General Land Office, but a theoretic land net has been superimposed on the accompanying map (Pl. XII) to facilitate reference. The township is included in the Caribou National Forest.

\section{STRATIGRAPHY.}

The rocks of the township are all sedimentary and belong to the formations included in the stratigraphic interval from the upper Mississippian limestone to the Thaynes limestone (Lower Triassic). They are, in ascending order, the Wells formation, the Phosphoria formation (including the Rex chert member), and the Woodside shale. Within half a mile of the southeast corner, rocks of Jurassic or Cretaceous age appear on the east side of a great thrust fault. 


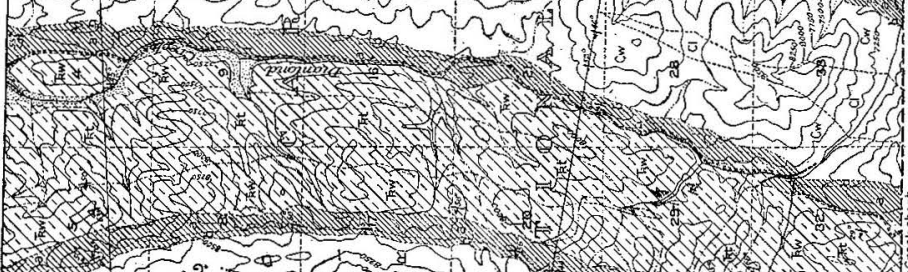

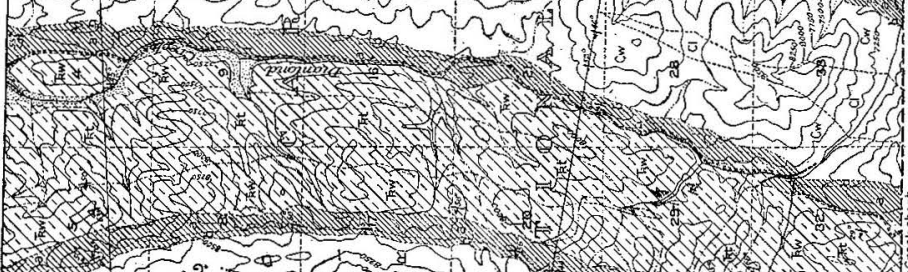
1.

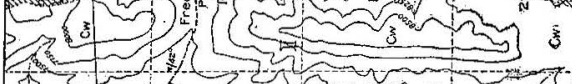

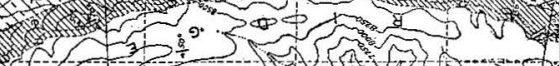

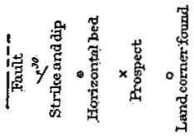

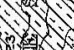

Din.

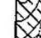
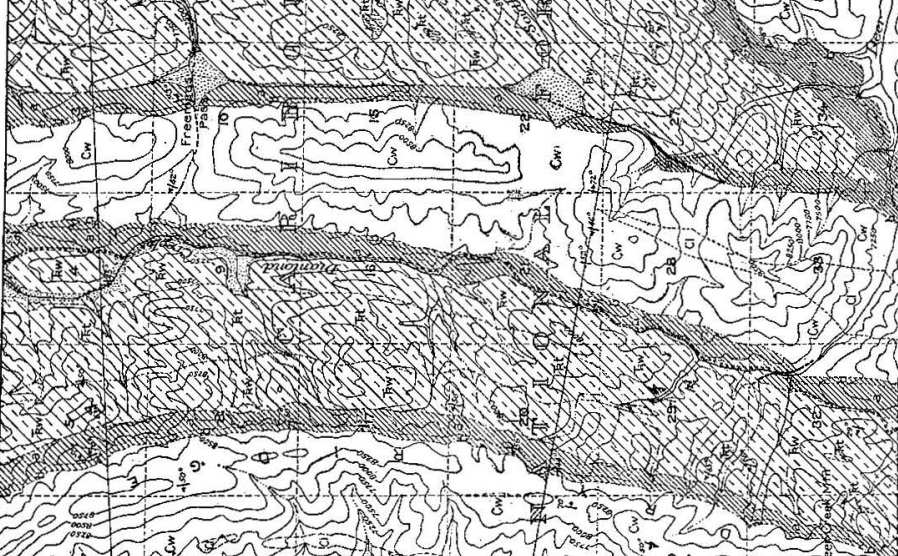
舟 

STRUOTURE.

The structural features of the township are developed on a large scale and are relatively simple. An anticline, normal and upright or only slightly inclined eastward, passes through the central part from south to north. On both sides of the anticline are synclines that broaden and pitch gently north. Beyond the synclines, near the east and west margins of the township, are other anticlinal axes. The outlines of the folds are fairly simple, though they have been modified locally by faulting.

The western syncline is relatively deep and narrow and is overturned eastward. The eastern syncline is broader and is also inclined toward the east. Minor folds within the greater synclines are indicated by the small infolded areas of Thaynes limestone.

Two minor thrust faults occur in the NE. $\frac{1}{4}$ sec. 32 and in the western half of sec. 27 , respectively. The east border of the eastern syncline is modified by a thrust fault of small displacement that begins about the center of sec. 24 and extends somewhat irregularly through the southeast corner of sec. 1. A small outlying thrust block, produced by this fault and now detached by erosion, overlies the border of the SE. $\frac{1}{4}$ sec. 13 and the NE. $\frac{1}{4}$ sec. 24 .

East of the township, extending from the NE. $\frac{1}{1}$ sec. 5 to the NW. 1 sec. 30, T. 9 S., R. 46 E., lies the west limb of another syncline that is broken on the east by the Bannock overthrust fault, which brings rocks of Carboniferous age over Jurassic and Cretaceous formations.

The northward projection of the great thrust fault from the townships to the south and southwest cuts off a portion of the bottom of the deep western syncline, and thus cuts out some of the phosphate shales. This interpretation, together with other details of structure, is shown in sections $A-B$ and $C-D$ on the map (Pl. XII).

\section{PHOSPHATE DEPOSITS.}

The phosphate deposits lie in two north-south belts across the township. The western belt has a constant width of about a mile, whereas the eastern belt ranges in width from about $2 \frac{1}{2}$ miles at the northern to half a mile at the southern boundary. The phosphate deposits are included in the Phosphoria formation, of supposed Permian age, as elsewhere in this general region.

Previous to 1911 no prospecting had been done in the phosphate shales. Members of the Survey party explored the natural exposure in the NW. $\frac{1}{4}$ SE. $\frac{1}{4}$ sec. 34 and obtained a partial section about 10 feet above the underlying limestone. The table following gives the measurements thus obtained and the results of the analyses of the samples taken: 
Partial section of phosphate shales in the NW. $\frac{1}{1}$ SE. $\frac{1}{4}$ sec. S4, T. 9 S., R. 45 E. of the Boise meridian, Idaho.

\begin{tabular}{|c|c|c|c|c|}
\hline $\begin{array}{l}\text { Field } \\
\text { No. of } \\
\text { speci- } \\
\text { men. }\end{array}$ & . & $\mathrm{P}_{3} \mathrm{O}_{5}$. & $\begin{array}{c}\text { Equiva- } \\
\text { lent to } \\
\mathrm{C}_{8}\left(\mathrm{PO}_{2}\right)_{2}\end{array}$ & \begin{tabular}{|l} 
Thick- \\
ness.
\end{tabular} \\
\hline $\begin{array}{l}\text { R } 446 \ldots . . \\
\text { (3) } \ldots \ldots . . \\
(1) \ldots \ldots . \\
(1) \ldots \ldots .\end{array}$ & 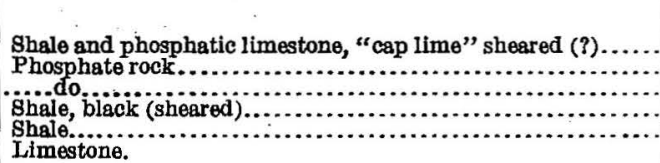 & \begin{tabular}{r|} 
Per cent. \\
32.0 \\
29.6 \\
4.4
\end{tabular} & $\begin{array}{r}\text { Per cent. } \\
69.9 \\
64.6 \\
\cdots \ldots . . .\end{array}$ & $\mid \begin{array}{rr}F t \\
1 & \text { in } \\
1 & 11 \\
2 & 2 \\
10 & 5 \\
10 & 0\end{array}$ \\
\hline
\end{tabular}

The above section shows a bed about 4 feet thick, represented by samples 2 and 3, that averages 65 per cent or more tricalcium phosphate. These figures are somewhat lower, both as regards thickness and quality, than those for the phosphate beds in adjoining townships to the northwest and southwest.

The upper portion of the shales, near the overlying chert, has not been explored, and there may be, as in Tps. 8 to 10 S., R. 44 E., beds of high-grade phosphate at that horizon. However, at this time it is safe to assume only the presence of the 4-foot bed measured.

On the supposition that the Bannock overthrust, which is believed to underlie the township, cuts off a portion of the bottom of the western syncline, as shown in the sections accompanying the map (Pl. XII), some of the phosphate deposits may have been destroyed. If a fair allowance is made for this loss, and the average dip is assumed to be $60^{\circ}$, the western syncline contains about 4,400 acres underlain by phosphate deposits. The eastern syncline, with an assumed average dip of $30^{\circ}$, contains about 8,160 acres, and thus the total is approximately 12,560 acres. As a cubic foot of phosphate rock weighs 180 pounds, the 4 -foot bed of phosphate rock that underlies this township is estimated at $171,400,000$ long tons.

In T. 9 S., R. 46 E., these deposits extend under an area estimated at 1,460 acres with an approximate tonnage of 20,442,000 long tons.

The deposits of the western syncline are accessible from the road in Diamond Creek, built by the Forest Service in 1911. The east side of the eastern syncline may be reached with little difficulty by the trails in the forks of Sage Creek. The interior of the eastern syncline and the west side of the western syncline lie in relatively high country to which there is no available means of access at the present time. However, several deeply cut canyons extend far back into the ridges and in these roads can be constructed without much difficulty. Trails used by sheep outfits are now found in most of the larger canyons. 
SURVEY.

The portion of T. 10 S., R. 45 E., lying west of the part of the Preuss Range locally known as Snowdrift Mountain was examined in a preliminary way by the Geological Survey in 1909. In 1910 the topography was mapped by Albert Pike in connection with the survey of the township to the west, and the base map of the remaining portion to the east was completed early in 1911. The detailed geologic survey by the writers immediately followed the topographic work.

\section{STRATIGRAPHY.}

The geologic age of the several formations which outcrop in the township ranges from upper Mississippian to Quaternary. Limestone and sandstones of Pennsylvanian age cover nearly half of the township, and the following formations listed in decreasing order of area, cover the remainder: Beckwith formation, Woodside shale, upper Mississippian limestone, Twin Creek limestone, Phosphoria formation (including at the top the Rex chert member), with minor areas of alluvium, Pleistocene clay, Nugget sandstone, and Thaynes limestone.

\section{STRUCTURE.}

In this township two masses of folded sedimentary rocks lie one above the other as a result of the Preuss Range overthrust. The underlying mass at its top is in general composed of younger rocks than are now included in the overlying block.

The character and distribution of the folds in the upper block determine the distribution of the phosphate deposits. These folds are shown in several cross sections on Plate XIII. They comprise a series of unsymmetrical anticlinal and synclinal folds of considerable magnitude. The major synclines are two in number and have the same distribution as that of the phosphate deposits described above. The principal anticlines are also two in number. The axis of the western fold practically coincides with the crest of Snowdrift Mountain; that of the eastern anticline lies along Crow Creek at the margin of the overthrust block.

Faulting has caused several modifications within the upper block. A thrust which is regarded as a branch of the main thrust has truncated the south end of the eastern syncline. Other faults occur in the northwestern part of the township, either marginal or medial to the western syncline. These faults apparently have greater vertical than horizontal components and probably should be classed as normal. 
The structure of the underlying block in this township is apparently somewhat more complex than that of the overthrust block. The exposure of the underlying block in the eastern part of the township, although narrow, shows clearly the existence of a series of compound folds with local faulting developed along the boundary between the Beckwith formation and the Twin Creek limestone. The structure of the greater portion of this underlying block is, however, undetermined.

The narrow area of the Rex chert member of the Phosphoria formation and the Woodside shale in the eastern part of the township is regarded as included between the main thrust and a branch thrust. The planes of the two faults probably coalesce westward at no great distance. The presence of valuable phosphate deposits between the two fault planes is doubtful.

PHOSPHATE DEPOSITS.

OCCURRETCE.

The phosphate deposits lie in parallel belts in the western and central parts of this township. Each belt has a western and eastern line of outcrop, and the two belts are separated by a high mountain mass of rocks older than the phosphate-bearing formation, which here as elsewhere in this region is of probable Permian age. The belts are the uneroded synclinal remnants of a rock series which undoubtedly at some early geologic period extended over the intervening anticlinal area. The western belt of deposits has been known for some time, and mineral claims were filed along both lines of outcrop following the discovery. The extreme eastern portion of the township undoubtedly contains the same phosphate deposits but at unrecoverable depths.

MEASURED SECTIONS AND QUALITY OF PHOSPHATE ROCK.

The phosphate deposits of this township have been prospected along only one of the four lines of outcrop, namely, that on the west flank of Snowdrift Mountain. Many openings, mostly shallow trenches, have been made by the Utah Fertilizer \& Chemical Manufacturing $\mathrm{Co}$. in the course of its assessment and patent work. Many of these openings show the character of the main basal bed, whereas others are superficial and do not penetrate to bedrock. Two cuts are especially complete and expose practically the entire section of the phosphate shales. The sections given on pages $24-26$ were measured at these localities and are thought to give a representative view of the quality and quantity of phosphatic materials which would be found in the unprospected portions of this township. Nearly all the strata appear to be highly phosphatic and include several high-grade beds. In considering these analyses it is well to bear in mind that the samples 
9nosgyaso

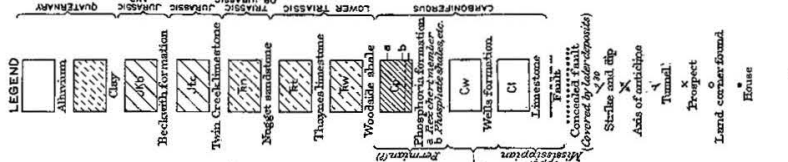

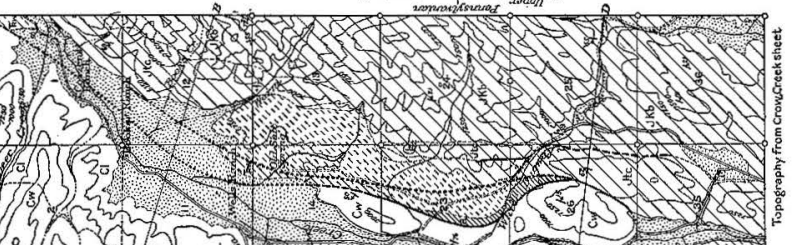

- $x^{2} y_{2}$

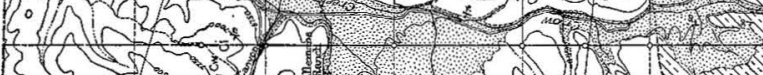

$\left\{\begin{array}{l}3 \\ \text { S }\end{array}\right.$

$150^{\circ}, 25$

$\int_{0}^{2} 20$.

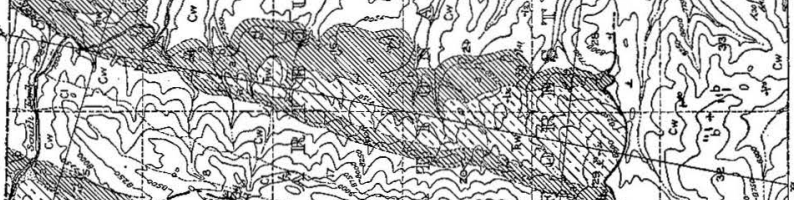

竞
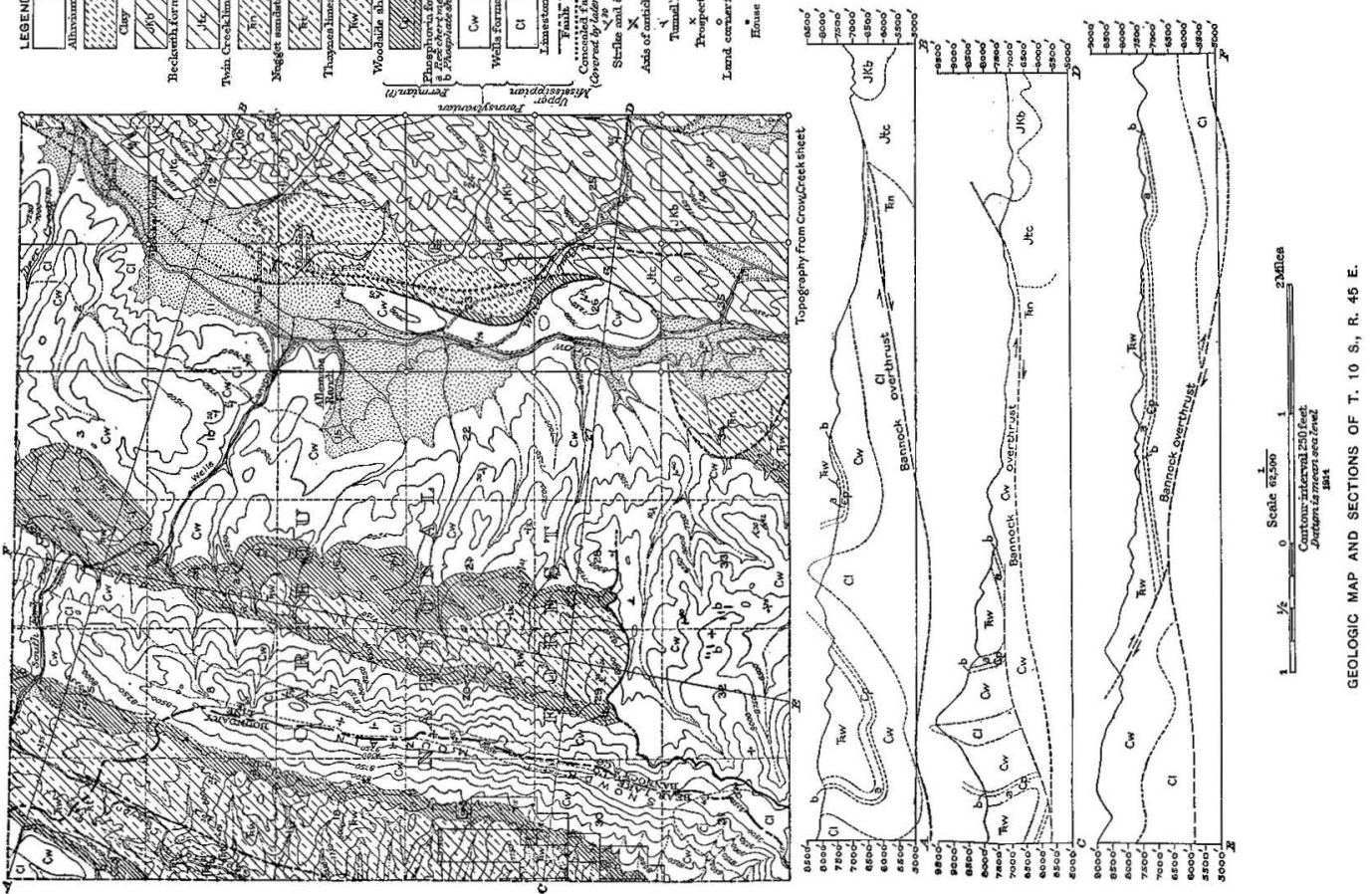

were taken near the surface and from beds nearly in vertical position. If enrichment along the outcrop has occurred these samples are above the average. Though the study of thin sections has not made it clear that concentration has taken place, yet theoretically it appears that the surficial leaching of the calcium carbonate would tend to cause local enrichment along the weathered zones. The inclusion of soil along the numerous minute surficial joints tends to act in the opposite direction and renders the deposits leaner on the outcrop than beneath the surface. It may well be considered, however, that in this particular locality the two processes about balance and that the results are characteristic of the deposits as a whole.

The main bed, as in the Montpelier district,' the phosphate section. It varies in thickness but appears to average about 6 feet in places where it has been fully opened. The rock phosphate is of high grade, carrying about 37 per cent phosphoric acid, equivalent to about 80 per cent tricalcium phosphate, as shown by the analyses. It is medium to coarse oolitic in texture and of dark grayish-brown color, almost black when fresh, and contains little foreign matter in the form of partings. It is capped by a single 2-foot stratum of dark fine-grained fossiliferous limestone.

AREA AND TONRAGE.

The area in this township which is underlain by the phosphate deposits is estimated to be 3,967 acres. Of this amount about 2,336 acres lie on the syncline west of the range and the remaining 1,631 acres on the eastern fold. The surface area of the main phosphate bed as bent up on the western fold is approximately two-fifths greater than that of the surface area of the land, so that the main basal bed comprises about 3,889 acres. The difference between the area of the overlying lands and the extent of the main bed is much less in the eastern fold, where the area of the bed is estimated to exceed that of the lands by one-eighth. A deduction has been made in this estimate for the area of phosphate which probably has been displaced by the subordinate thrust from its position under the normally overlying chert and Woodside shale in secs. 28 and 29.

The total area of the main basal bed is thus about 4,236 acres. On the assumption that the average thickness of the bed throughout this extent is 6 feet, the contained tonnage of high-grade phosphate rock is $88,900,000$ long tons. All the high-grade rock included in this estimate is ultimately available, as the greatest depth from favorable points of entry is less than 2,000 feet.

The phosphate content of the entire section of the phosphate shales is probably several times the above estimate-that is, in highgrade rock alone - and an enormous tonnage of low-grade material is present which may at some future date prove of great value.

1 Gale, H. S., and Richards, R. W., O. S. Geol. Survey Bull. 430, pp. 488-495, 1910. 
DEVELOPMENT.

Practically none of the exploratory work which has been done by the Utah Fertilizer \& Chemical Manufacturing Co. can be utilized in the actual mining of the deposits, with the possible exception of the tunnel in the southeast corner of the Hillside claim. This tunnel by bearing due east will cut the phosphate shales at a distance of about 1,000 feet. The last 500 feet would penetrate the overlying chert. It is possible that the portions of the three beds, $144 \mathrm{G}, \mathrm{I}$, and S (pp. 24-25), above the level of this tunnel and for a distance of 2,000 feet in both directions along the outcrop, can be feasibly removed through it. The capacity of this tunnel is in round numbers 660,000 long tons of rock of over 70 per cent tricalcium phosphate. The cost of proper equipment for transporting this tonnage 'to the main line of outlet in Georgetown Canyon, a distance of three-fourths mile, should be compared with a scheme of underground haulage to that point through a system of workings at lower levels with a higher total capacity.

Any general scheme of development of the western phosphate area will of necessity have to be worked out in connection with the natural extension of this area in the township to the west.

The development of the eastern syncline will naturally start at the eastern margin and will be dependent on the construction of a railroad in the valley of.Crow Creek. The most favorable points of entry are situated on Deer Creek, immediately north of the township line, and on the unnamed creek which runs easterly across secs. 21 and 22. Short tunnels transverse to the axis of the fold with extraction drifts paralleling the axis will permit the easiest movement of the rock and present undoubtedly the most economical mining procedure for large-scale operation.

OWNERSHIP.

The title to about 2,767 acres of the total area of phosphate land in this township is vested in the United States Government. The Utah Fertilizer \& Chemical Manufacturing Co., under claims filed under the provisions of the mineral-land laws, holds 780 acres. The State school land in sec. 16 includes about 405 acres bearing phosphate.

SALT DEPOSITS.

The marginal region of the great thrust on Crow Creek bears salt deposits which give rise to saline springs. The only one of the springs which has been utilized as a source for brine is located in sec. 14. The origin, distribution, and economic bearing of these deposits have been discussed by C. L. Breger. ${ }^{1}$

1 Breger, C. L., The salt resources of the Idaho-Wyoming border, with notes on the geology: U.S. Geol. Survey Bull. 430, pp. 555-569, 1910. 
T. 11 S., R. 45 F.

SURVEY.

A detailed geologic survey was made of the entire township except secs. 24, 25, and 36, which are underlain by the southward continuation of the Beckwith formation, examined farther north, which lies high above the phosphate. In the northwest corner of the township, where the phosphate beds outcrop, the survey was made with plane table and alidade. Elsewhere locations were determined by pocket compass sights, which were considered sufficiently accurate.

The field sheet of the Montpelier quadrangle, enlarged from a scale of $1: 96,000$ to the scale of $1: 31,680$, was used for the topographic base and the geologic work was done on the latter scale.

Collections from the Carboniferous rocks of the northwest part of the township were made by G. H. Girty. E. H. Finch, of the Survey, spent three days in examining parts of the township.

The land net as given on the Montpelier sheet was accepted and used in the geologic survey.

\section{STRATIGRAPHY.}

The rocks of the township range from early Carboniferous to Pliocene ( $($ ) , the oldest rocks lying in the northwest part and the youngest in the east and southeast parts.

The Madison limestone has been recognized at only two localities in this township, namely, in the NW. 1 sec. 17 and the NE. $\frac{1}{4}$ sec. 19, where it appears in an eroded anticline or anticlines in the upper Mississippian limestones. The formation appears in normal facies with characteristic fossils.

The upper Mississippian limestones form the ridge that extends from sec. 20 to the northwest corner of the township and culminates in Meade Peak (9,953 feet in altitude) in the SW. 1 NW. $\frac{1}{1}$ sec. 6, the highest point within the area described in this report. The limestone is characteristically developed and locally well supplied with fossils. It is marked by rough craggy ledges and rugged topography and forms picturesque mountain scenery.

The.lower Pennsylvanian sandy limestones, sandstones, and quartzites of the Wells formation occur in two general areas. The smaller area lies about the head of the south fork of Georgetown Canyon in secs. 7 and 18. The larger area occupies a part of secs. 4, 5, and 6 . These localities are marked by somewhat smoothed and rounded topographic forms with abundance of sandy float, which weathers white or dull red, but outcrops are comparatively rare. Even the $37002^{\circ}-14-5$ 
limestone that comprises the top of the formation and underlies the phosphate beds is here less well marked as a cliff maker than is the rule farther north, and it has few outcrops.

The Phosphoria formation is well developed in two localities bordering the formation just described and extends also into the northern part of sec. 8. The lower or phosphate-bearing portion is not actually exposed by open cuts or prospects in this township, but its presence may readily be determined by float along the line where it approaches the surface. Topographically it is represented by depressions or saddles on the ridges, and by valleys. In secs. 4 and 5 it occurs in a small canyon tributary to the Crow Creek system. The Rex chert member is well represented in both localities and, so far as observed, consists solely of heavy chert layers without fossils. In secs. 4 and 8 and 3 and 9 the chert forms remarkably fine dip slopes of bare rock along the north side of Crow Creek.

The Woodside shale occupies a belt from a quarter to half a mile wide, extending from the middle of sec. 8 northeast through sec. 3 . In this belt the rock is rather massively bedded, though still retaining its sandy character and its yellowish and greenish tints. A particularly fine exposure of a portion of these beds occurs on a knob above Crow Creek in the SE. $\frac{1}{4}$ SE. $\frac{1}{4}$ sec. 4 , where fine ledges descend nearly 800 feet to the bottom of the creek. Another smaller area forms a narrow band extending from the northern part of sec. 18 through sec. 7 into sec. 12 , T. 11 S., R. 44 E., where it expands and underlies a large part of the south fork of Georgetown Canyon.

The limestones and shaly limestones of the Thaynes formation occupy a large district from half a mile to 2 miles wide, extending from the NE. $\frac{1}{4}$ sec. 20 northeast through sec. 3 . Topographically, the formation is represented by high hills with smoothed slopes and few outcrops. The basal member or Meekoceras zone is readily identified and traced. Much of the region underlain by this formation is difficult of access because of brush, timber, and windfalls. The Meekoceras and associated fossiliferous zones are well exposed along the ridge south of Crow Creek in secs. 8 and 9.

The Ankareh shale has not been definitely recognized in this township. Some red sandy and shaly beds, however, occur along the east border of the Thaynes limestone.just described. In some localities, particularly in the SW. $\frac{1}{4}$ SE. $\frac{1}{4}$ sec. 10, gray limestone bands (and. some anhydrite?) are interbedded with the red shales and sandstones, so that the whole strongly suggests the Ankareh shale. But the relation of these beds to the Twin Creek limestone on the east, the well-developed Nugget facies of the red sandstones in this same band in the township to the north, together with the fact that similar calcareous and shaly bands occur at the top of the Nugget sand- 
stone in Dunns Canyon in sec: 10, T. 11 S., R. 44 E., all point to the view that the red beds here mentioned belong in the upper part of the Nugget sandstone rather than in the Ankareh shale, and they are so interpreted. It is possible that the Ankareh may occur at the bottom of the canyon in the SW. $\frac{1}{4}$ sec. 32 within the Nugget sandstone area there shown, but this point has not been determined.

The main occurrence in this township of the Nugget sandstone, which is made up chiefly of sandstones and quartzites, has just been described. These beds also occupy most of the SW. $\frac{1}{2}$ sec. 32 and a small portion of sec. 31. Here the typical reddish, whitish, and buffcolored sandstones, with dark iron-stained weathered float, are present. The formation constitutes the core of an anticline that enters the township from the southeast.

The Twin Creek limestone includes most of the southwest quarter of the township and extends in a broad band from sec. 22 northeast through sec. 2. So far as observed this formation is here represented almost entirely by the chippy, shaly whitish-gray limestone facies. The rock maintains steep slopes covered with littlo chippy fragments. The west side of Montpelier Creek from sec. 19 southeast gives an excellent example of such a slope. The country underlain by this formation supports little vegetation and presents a dreary aspect.

The Beckwith formation of red sandstones, shales, and conglomerates underlies the entire eastern tier of sections and a considerable portion of the second tier. The predominant color is red, though some of the sandstones of the formation contain bands of brown, gray, or white. In the northeast part of the township this formation is largely conglomeratic and makes ridges and knobs. Red Mountain, bordering sec. 12 and extending into the adjoining township, is the most conspicuous topographic feature of this formation in this township.

The Pliocene (?) is represented in this township by a belt of strata about a quarter of a mile wide, lying in a depression in the Beckwith formation from sec. 1 to sec. 13. In the northern part the beds are well-defined white marly grits and conglomerates. Farther south they are more influenced by the red material from the adjacent red beds and their boundaries are less well defined.

A somewhat crescent-shaped area of travertine is found in portions of secs. 3 and 10 . In some places, notably on the spur above Crow Creek in the north part of sec. 10, the rock contains pebbles of other rock and resembles to some degree the marly beds of the supposed Pliocene. Elsewhere the banded calcareous material bears evidence of deposition from springs, and the resemblance to the Pliocene (?) deposits is not close. 


\section{STRUOTURE.}

In this township faulting has occurred on a considerable scale and folding has also taken place in probably two epochs at least. An area including somewhat more than the northwest quarter of the township constitutes part of a great thrust block that comprises rocks varying in age from the Madison limestone to the Thaynes. These rocks are folded into anticlines and synclines that were doubtless formed in the earlier period of folding and may have been intensified or modified by the later folding.

Meade Peak appears to form part of a closely folded anticlinorial ridge which lies between two broken synclines that contain the phosphate deposits of the township. North of Meade Peak the ridge trends northeast, but southward it trends southeast and south. The two phosphate-bearing areas appear to be portions of larger synclines to the north, which have been detached by faulting.

The Bannock overthrust, which enters the township in the NW. 1 sec. 19, branches in the eastern part of sec. 20. The western branch separates the Carboniferous from the Triassic (Thaynes limestone), and the eastern branch separates the higher portions of the Thaynes limestone from the top of the Nugget sandstone. The western branch diminishes northward in stratigraphic throw and dies out in the southern part of the adjoining township on the north. The eastern branch continues northward with increasing throw and becomes the dominant thrust in regions to the north. The relations of the thrust block to the underlying rocks may be very clearly seen on the north side of the upper canyon of Montpelier Creek in secs. 19 and 20, where rocks of Madison and upper Mississippian age, marked by rough craggy topography, overlie the splintery shaly limestones of the Twin Creek formation. The topographic contrast is very striking, and the contact may easily be traced along the sides of the valley. The stratigraphic displacement here amounts probably to not less than 8,500 feet.

The thrust block itself was probably contemporaneous with the earlier folding and represents a great eastward movement of the older rocks from the west over the younger formations to the east. Subsequently it seems to have suffered compression from the east, for the eastern branch of the fault now has a steep westerly hade, whereas the western branch in sec. 8 has an easterly hade of about $42^{\circ}$. It seems clear, nevertheless, that this western branch is really a part of the thrust fault and not an independent normal fault, because it may easily be traced along the saddles at the base of the ridge into the thrust fault in Montpelier Canyon, and the hade changes from east to west as the branching point is approached. This later folding is also shown by a subsidiary thrust that marks off the phos-. phate basin in secs. 18 and 7 . Here, too, the fault plane has been 


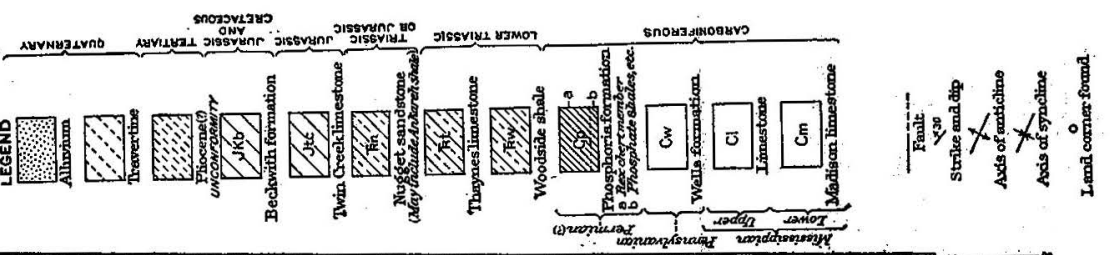

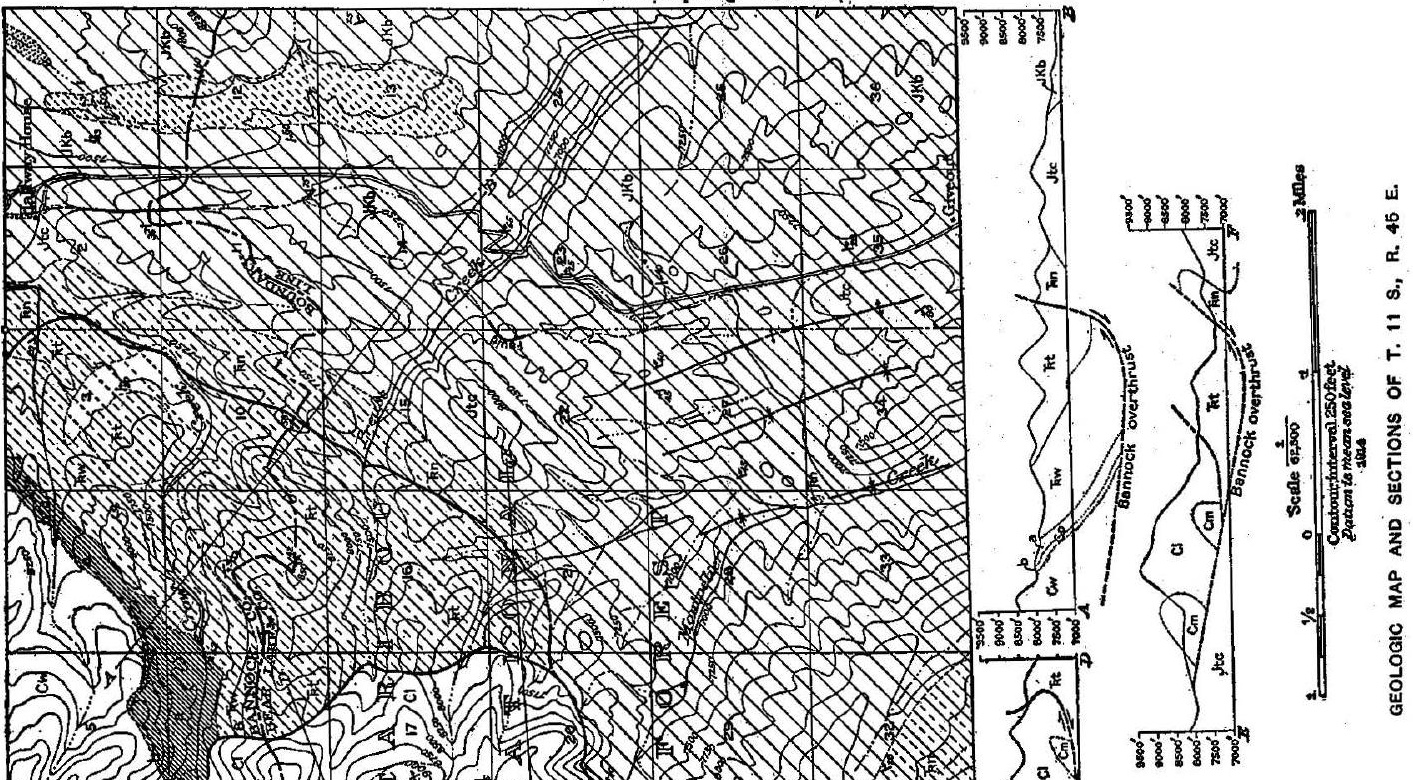



folded, and from the unequal thicknesses of the existing portions of the formations that accompany the phosphate it is inferred that the bottom portion of the phosphate syncline has been truncated by the fault. The relations above outlined are indicated in the sections drawn along the lines $A-B, C-D$, and $E-F$ on Plate XIV.

The boundary between the Twin Creek limestone and the Beckwith formation is marked locally by slight faulting, particularly in secs. 2, 11, and 22. The two formations; with discordant dips, occupy opposite sides of deeply cut valleys, and varicolored clays, suggestive of fault clay, are exposed here and there along the general contact line. To the north the fault plane is steep and apparently normal, with the downthrow on the east. Farther south the contact between the formations is less regular and has a much more gentle inclination. The faults appear to die out in both directions.

The SW. 1 sec. 35 is occupied by the southern apex of an eroded cigar-shaped anticline in the Twin Creek limestone, the axis of which extends northwest into sec. 22. The form of the fold is preserved in spite of the erosion that the region has undergone and is so clear as to be almost diagrammatic. To the west lie other axes, both synclinal and anticlinal. The eastward dips are steeper than the westward dips, giving unsymmetrical folds inclined eastward.

In secs. 31 and 32 the Nugget sandstone appears as the core of another anticlinal fold that enters the township from the southeast. This fold is also unsymmetrical and is overturned toward the east.

\section{PHOSPHATE DEPOSITS.}

Phosphate rock comes to the surface only in secs. $3,4,5,7,8$, and 18, but it probably underlies most of the rest of the township, except the areas of Carboniferous rocks older than the phosphate rock, at depths too great to make it available. No openings have thus far been made in the phosphate beds in this township, so that the character of the rock can be determined only by the fragments of float on the surface, which seem to indicate deposits comparable in nature and thickness with the neighboring deposits in Georgetown Canyon to the northwest, where numerous prospect pits have been opened.

The estimated area underlain by phosphate rock at depths not greater than 2,500 feet, bounded at the surface by the Meekoceras zone or base of the Thaynes limestone, is 1,260 acres, or nearly 2 square miles. On the assumption that the high-grade phosphate bed is 5 feet thick, a reasonable assumption in view of the known thicknesses in neighboring townships, and that the weight of a cubic foot of high-grade rock is 180 pounds, this area would contain over $22,000,000$ long tons if the rocks were horizontal. The dips within the district are somewhat variable, but perhaps $40^{\circ}$ may be taken as a fair average. On this basis the above estimate would be increased 30 per cent. If the estimate were made to include rock as 
much as 3,000 to 3,500 feet below the surface there would be added the area underlain by the Thaynes limestone, which would add a little more than 2 square miles to the total already mentioned, and would more than double the estimated tonnage.

It should be remembered, however, that this entire area constitutes part of a great thrust block and is underlain in all probability by a fault plane, which may cut out much or all of the deeper portions of the deposit. In the absence of drill records it is impossible to state with certainty the depth at which the fault plane lies. It is possible too that the assumed thickness of the phosphate bed may be greater than the actual thickness, although this seems unlikely. In view of these circumstances it seems wiser to submit the estimate as first given-namely, 22,000,000 long tons, which is surely conservative.

The phosphate deposits are accessible through the valleys of Crow Creek and the south fork of Georgetown Canyon respectively. Much of the phosphate rock is above water level.

\section{GENERAL SUMMARY OF AREAS EXAMINED.}

The tonnage estimates included with the township descriptions accompanying this report cover only the area examined in detail in 1911 and are additional to the estimates for 1909 and 1910. Although these estimates are approximate, they are derived from the most complete data available at the present time. Emphasis should be placed on the fact that all these estimates, like those of the previous years, are based to some extent on assumptions which are, however, carefully explained in the accompanying text. All the estimates made are intended to be moderate. They are confined to the content of the main bed, which lies in the greater part of this area near the base of the phosphate shales, and no attempt is made to estimate the vast tonnage of the intermediate or low-grade rock.

Estimates of phosphate rock available in the townships reviewed in this report.

T. 8 S., R. 44 E..............................

T. 9 S., R. 44 E..............................

T. 10 S., R. 44 E.............................

T. 11 S., R. 44 E............................

T. 8 S., R. 45 E...............................

T. 9 S., R. 45 E.............................

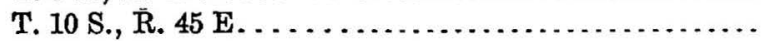

T. 11 S., R. 45 E..............................

Total for area examined in 1911 . Long tons. $386,400,000$ $164,600,000$ $52,000,000$ $2,170,000$ $459,900,000$ $171,400,000$ $88,900,000$ $22,000,000$

Total for area examined in $1910 \ldots \ldots \ldots \ldots \ldots \ldots 1,158,970,000$

Total for area examined in 1909 minus 90,000,000 tons, estimate for Georgetown district, which is duplicated in the total for $1911 \ldots \ldots \ldots \ldots \ldots \ldots \quad 156,950,000$

Total tornage for area covered with detailed surveys to date. . . . . . . . . . . . . 


\section{NATURE AND ORIGIN OF THE ROCK PHOSPHATE.}

\section{GENGRAI CHARACTER.}

The rock phosphate is characterized by an oolitic texture, which, however, may be lacking when the grain of the rock has been destroyed by pressure or by shearing. The ovules or oolites are rounded grains built up in roughly concentric structure and range in size from extremely minute specks to bodies half an inch or more in diameter. Many of these oolitic bodies are irregularly flattened, suggesting that they have actually existed as pebbles and been worn by attrition upon one another. The ovules are in general darker than the matrix and a few of them possess a black, shiny coating which is similar in appearance to desert varnish.

The rock when fresh usually possesses a dark-brown color, but the weathered material found on the outcrop is predominately a light bluish gray. The rock that has lost its oolitic texture through metamorphism by pressure appears to retain the darker original color even after long exposure. The bluish-gray coating (somewhat like chalcedony in appearance) has a tendency to concentrate along lines in a netlike pattern. These lines are very apparent on the darker-colored rock and are of assistance in following scattered float along the phosphate beds which lie near the surface.

The phosphate rock and the limestone closely associated with it yield when struck a characteristic fetid odor which is described by some as bituminous and by others as more nearly sulphurous. One feature on which all agree is that the odor, though not particularly disagreeable, is exceedingly penetrating. The intensity of the odor given off by the rock when struck is by no means an indication of its phosphatic content.

\section{ORIGINAI SFDINFNTARY DEPOSITS.}

The rock-phosphate deposits of the Idaho, Utah, and Wyoming fields are original sedimentary formations laid down at a time when that part of the earth's surface was largely covered by water. Since the time in which the phosphatic strata were deposited other rockforming sediments have been accumulated, so that many thousands of feet of subsequent strata have overlain or succeeded them. Deformation of the earth's crust has tilted, folded, and in many places broken these strata, which originally lay flat. Uplift of the land or recession of the sea has subjected the rock in its disturbed position to stream erosion and the action of atmospheric agencies, so that great bodies of the more elevated parts have been removed entirely and the truncated edges of the rock strata are now exposed at the surface. The occurrence of the rock phosphate at the surface of the ground now depends on the geologic structure and more or less acci- 
dental relationships, such as absence of masking cover or later deposits, depth of erosion, and many minor factors.

The rock-phosphate deposits are thus more properly analogous to coal and limestone and especially to the Clinton iron ores of the Appalachian region than they are to ore deposits such as veins or lodes or to alluvial deposits of the placer type.

\section{SPECIFIC GRAVITY.}

A series of experimental determinations of the density of the rock phosphate was made in the laboratory of the United States Geological Survey and is described in detail in the report for 1909.1 The average specific gravity of rock containing 70 per cent tricalcium phosphate was found to be about 2.9. No further data on this subject have been collected and this figure has been used in the tonnage calculations of the present report.

\section{MINERAL AND CHEMTCAL COMPOSITION.}

The mineral composition of the western rock phosphate is not yet completely ascertained, and the problem is difficult of solution, owing to the mode of occurrence of the constituent minerals. Thin sections of the richest oolitic ore show under the microscope that the rock consists mainly of ovules or concretions of a cryptocrystalline substance which, in some concretions, is surrounded by banded zones of crystalline fibers with local isotropic bands, all having the same average index of refraction (about 1.60) and apparently representing the phosphatic substance. In some places the interstices are filled with calcite and in others with an isotropic material which appears to be identical with the substance that forms the cores of the concretions. The extinction of the double-refracting mineral is parallel to the elongation of the fibers, but the optical character of this mineral can not be determined because of the absence of cleavage or crystal faces.

The isotropic substance probably represents collophanite,

$$
x\left(\mathrm{Ca}_{3}\left(\mathrm{PO}_{4}\right)_{2}\right) \text { or } x\left(\left(\mathrm{CaF}_{2}\right) \mathrm{Ca}_{8} \mathrm{PO}_{4}\right)_{6}+y \mathrm{CaCO}_{3}+z \mathrm{H}_{2} \mathrm{O} \text {, }
$$

and the double-refracting substance is possibly quercyite. Quercyite comprises a variable mixture of the series of lime-phosphate minerals, including collophanite, described by Lacroix ${ }^{2}$ from the French phosphorites.

The ovules include minute curly, hairlike, and branching plant fragments, whose appearance strongly suggests that they represent fungi.

I U. S. Geol. Survey Bull. 430, pp. 463-464, 1910.

2 Lacroix, A., Sur la constitution minéralogique des phosphorites français: Compt. Rend., vol. 150, p. 1213, 1910; Minéralogie de la France, vol. 4, pt. 2, p. 555, 1910. 
Chemical analyses of the rock phosphate of the western field are published in the report for $1909 .{ }^{1}$ No additional complete analyses have been made.

\section{DETERMINATION OF PHOSPHORIC ACID.}

The phosphoric acid determinations published in this report were made by John G. Fairchild in the chemical laboratory of the United States Geological Survey after improved methods which have been developed by him. ${ }^{2}$

\section{ENRICHMENT BY WEATHERING.}

A tendency toward enrichment of the content of phosphoric acid is shown in the weathered outcrops of the rock-phosphate beds. As this would naturally be expected from the chemical and mineralogical composition of this material, no extensive examination has been undertaken to verify this conclusion. An average sample of the main bed, taken at the surface at Montpelier in 1909, ran 4 per cent higher in phosphoric acid than the average samples taken in the same year at the Waterloo mine, and J. J. Taylor, the superintendent of the property, reports that a still lower content was found in the bed as cut by a bore hole at comparatively shallow depth. This evidence is probably insufficient on which to base general conclusions, but the mining operations in other parts of the field seem to demonstrate that fresh clean rock from the thicker workable beds usually maintains an average content exceeding 32 per cent of phosphoric acid.

Positive information about the character of these deposits at greater depth is needed, as it must be admitted that all the data collected at present have come practically from the outcrop, and only theoretic foundation exists for statements concerning the character of the greater volume of the rock included in the tonnage estimates.

The importance of the phosphate deposits still in public awnership is greatly enhanced if only the outcrop of these deposits is of present commercial value, and it is therefore imperative that a study of the quality of these deposits under cover should be conducted by systematic drilling prior to their disposal and development.

\section{IRON AND AIUMINA.}

Iron and alumina in phosphate rock in excess of 3 to 4.5 per cent in the eastern fields are considered as placing the ore below foreign contract standards. These substances are supposed to produce in the present process of superphosphate manufacture deliquescent salts which render the drying and shipment of the product difficult. In

\footnotetext{
1 U. S. Geol. Survey Bull. 430, p. 465, 1910.

2 Fairchild, J. G., The accurate volumetric determination of phosphoric acid in phosphate rock: Jour. Ind. and Eng. Chemistry, vol. 4, pp. 520-522, 1912.
} 
all samples from these fields that have been tested in the laboratory of the Geological Survey less than 1 per cent of either radicle computed in the oxide form was found. The manufacturers of superphosphate using the rock from the western field agree that the amounts of these substances present are too small to be considered objectionable.

\section{SOURCE OF PHOSPFORIC ACID AND PROBLEM OF ITS ACCUMULATION.}

An adequate explanation of the accumulation of the enormous amount of phosphoric acid locked up in the phosphate deposits of the western fields has not been given. The ultimate source of the phosphoric acid clearly must have been the phosphate-bearing minerals of the igneous rocks, of which apatite is the most abundant.

Whether or not the concentration of the acid and its combination into a lime phosphate has been accomplished largely through the action of life agencies rather than through purely chemical and physical means is a mooted question. Shells of Lingulidiscina, a phosphate-secreting brachiopod; are associated in great abundance with the phosphate in portions of the Wyoming field, but are generally absent from the greater portion of the phosphate areas studied, and the rocks contain no other fossils representing known phosphatesecreting forms. It seems scarcely probable that such fossils would have been completely destroyed in the processes of deposition. The absence of these fossils and the fact that the rocks immediately associated with the beds of rock phosphate are shales that represent conditions somewhat unfavorable to the abundant animal life tend to cast doubt on the theory that the phosphate was concentrated by means of living organisms.

It seems to the writers to be a suggestive coincidence that water charged with carbon dioxide is the best natural solvent of the mineral apatite, so far as known, and that according to a rather prevalent assumption the atmosphere of Pennsylvanian time was rich in that gas, though the recent decision that the phosphate deposits are of later age (probably Permian) appears to weaken the significance of such a coincidence. Possibly, however, though the solution and accumulation may have occurred while the atmosphere was rich in carbon dioxide, the concentration and deposition may have taken place largely during a subsequent period of decrease in the quantity of that gas in the atmosphere.

It is apparent, however, that too little is known at present concerning the land and marine conditions that prevailed during the process of formation of the phosphate deposits to permit the formulation of a satisfactory hypothesis. It is hoped that further light on this question will be obtained before the investigation of the western phosphate fields is completed. 


\section{INDEX.}

A.

Page.

Access, moans of

Alluvium, occurrence and character of

$7-8,14,49$

Ankareh shale, distribution and character

$$
\text { of. }
$$$$
\text { of.................... }
$$

B.

Bannock overthrust, age of

features of

magnitude of.

section of.

stereogram showing

.

Basins, distribution and character of ......... 12-13

Beckwith formation, occurrence and character of............................ 16, 33, 67

Blackwelder, Eliot, work of .............. 9,20,21

Boutivell, J. M., cited.

Breger, C. L., work of .

C.

Carboniferous system, fossils of. .. $1^{7}$ occurrence and character of. $16-29,42,46$

Clays, occurrence and character of

Cretaceous system, occurrence and character of.......................... 16, 33

D.

Drainage, description of.

11-12

E.

Enrichment, processes of

Erosion, cycles of

\section{F.}

Fairchild, J. G., work of.

Fans, alluvial, distribution of

Ferrier, W. F., and Weeks, F. B., work of

Field work, extent of.

Finch, E. H., work of.

\section{a.}

Gale, H. S., work of 9 Ct. 10-11, 22 Geography, account of.................... 11-14 Geological Survey, U. S., investigation by...

Georgetown Canyon, section in. ... 24-25 view of ........................ 37 (PIV) Girty, G. H., fossils determined by........ 17$18,20,21,23,24$

on age of rocks 18,19 work of

\section{I.}

Igneous rocks, occurrence and character of... 34,43 Industries, character of.
J.

Page.

Jones, C. C., on phosphate discovery ........ 7 Jurassic system, occurrence and character of. . ' 16,

M.

Madison limestone, distribution and character

of........................ 16,17,65

fossils of ............................. 17

Mansfield, G. R., ackmowledgments to........ 8

work of ............................... 9,11

Map of phosphate reserves.................. 10

of townships........................ 15

See also particular townships.

Map, geologic, of townships................. 15

Meade Peak, elevation of ................... 11

view of........................ 10 (Pl. I)

Meade Peak district, phosphate rock of...... 55-56

Mendenhall, W.C., aid of................... 9

Mineral laws, omission in ................. 8

Mississippian series, fossils from............... 17-18

occurrence and character of............. 16-18

N.

Nugget sandstone, distribution and character of...................... 16,32,66-67

o.

Overthrust. See Bannock overthrust.

\section{P.}

Panorama......................... 38 (Pl. IV)

Peale, A. C., work of...................... 10

Pennsylvanian series, distribution and character of ................... 16,18-21,65

fossils of .......................... 20, 21

Permian series, fossils of ................... 23,24 occurrence and character of.......... 16, 22-29

PLosphate lands, acquisition of............. 7-8 investigation of......................... 8 map of.............................. 10 withdrawals of ....................... 8,9 See also particular townships.

Phosphate rock, alumina in............... 73-74

amounts available of................... 70

character of.......................... 71

chemical composition of . .............. 72-73

enrichment of. ....................... 73

fold in.................... 45 (Pl. VIII)

iron in............................... 73,74

mineral composition of ............... 72

occurrence of. .......................... 24-29

origin of ............................... $71-72$

specific gravity of.................... 72 
Page.

Phosphoria formation, correlation of........ 22-23 distribution and character of .... 16, 22-29, 41-42 fossils of . ............................. 23,24 phosphorus in . sections of .......................... 24-29 view of 44 (Pl. VII)

Phosphoric acid, source of................ 74

Phosphorus, amounts available of ......... 70 occurrence of. ......................... 2t-29 See also particular townships.

Physiography, description of............. 11-13 Pidcock, R. A., discovery by............. 7 Pliocene series, occurrence and character of. 16, Q.

Quaternary system, occurrence and character of.

R.

Ragar, E. C., work of

Railroads, construction of. . ................

Rex chert member, distribution and character of...................16,22, 23,66

fossils of.

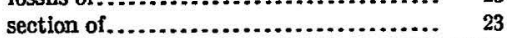

view of....................... 44 (Pl. VII)

Richards, R. W., acknowledgments to...... 8 work of............................... 9,11

Richter, Albert, discovery by ............. 7

\section{s.}

Balt, occurrence and character of

Schultz, A. R., work of.

Section reneral in phosphate arog.

Blug Valley, description of.

section in............................ 29

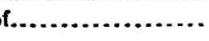

view in...................... 44 (Pl. VII)

Snowdrift Mountain, elevation of.......... 11

South Canyon, view of. ................ 10 (P1. I)

South Canyon district, phosphate rock of ... 50-55 phosphate rock of, character of .......... 51 sections of ..................... 51,52,53

Speciflc gravity of phosphate rock......... 72

Spring deposits, occurrence and character of.. 34

Stereogram, showing Bannock overthrust....................... 36 (Pl. III)

Stratigraphy, details of................... 17-34 outline of . .............................. 14-16

Structure, description of................... 34-38 topography adjusted to................ 12

\section{T.}

Terraces, distribution of.....................

Tertiary system, occurrence and character of........................ 16,33,46

Thaynes limestone, distribution and character of .................30,31,42,46,66

T. 8 S., R. 44 E., geology of................. 39 map of......................40 (PI. V) phosphate deposits of................ 39-40,70 sections in 40 (PI. V)
Page.

T. 8 S., R. 45 E., geology of................ 56-57 map of .......................... 56 (PI. XI) phosphate deposits of .............. 57-58,70 sections in....................... 56 (PI. XI) survey of ............................. 50

T. э S., R. 44 E., geology of................ 41-42 map of ........................ 42 (PI. VI) phosphate deposits of............... 44-45,70 sections in...................... 42 (Pl. VI)

T. 9 S., R. 45 E., geology of................ 58-59 map of ......................... 58 (Pl, XII) phosphate deposits of............... 59-60,70 sections in .................... 58 (Pl. XII) survey of ............................ 58

T. 10 S., R. 44 F., geology of ............... 46 map of......................... 46 (Pl. IX) phosphate deposits of............... 47-49,70 sections in...................... 46 (Pl. IX) survey of ........................... 46

T. 10 S., R. 45 E., geology of............... 61-62 map of . . .................... 62 (Pl. XIII) phosphate desposits of.............. 62-64,70 salt deposits of....................... 64 sections in ..................... 62 (Pl. XIII) survey of............................. 61

T. 11 S., R. 44 E., geology of.............. 49-50 map of........................... 50 (PI. X) phosphate deposits of............... 50-56,70 section of........................... 50 (PI. X) survey of .............................. 49

T. 11 S., R. 45 E., geology of . . . . . . . . $65-69$ map of......................... 68 (Pl. XIV) phosphate deposits of................... 69-70 sections of ...................... 68 (Pl. XIV) survey of ............................. 65

Townships, detailed descriptions of......... 38-70 geologic map of........................ 15 See also particular townships.

Transportation, means of................... 13 Travertine, occurrence and character of...... 34 Triassic system, fossils of .................... 30 occurrence and character of ........... 16, 29-32

Troxell, E. L., work of.................... 9 Twin Creek limestone, distribution and charseter of.................... 16,32-33 U.

Upper Mississippian limestone, distribution and character of ...........16,17-18,65 fossils from. $17-18$

$$
\mathrm{V} \text {. }
$$

Valleys, description of $\ldots \ldots \ldots \ldots \ldots \ldots \ldots \ldots \ldots$
Van Horn, F. B., work of ...................... W.

Weeks, F. B., and Ferrier, W. F., work of... 10 Wells Canyon, section in.................. 19-20 Wells formation, fossils from............... 20,21 distribution and character of.... 16, 18-21, 65-66 section of................................ 19-20 views of ........... 44 (Pl. VII), 45 (Pl. VIII)

Woodruff Creek, Utah, phosphate on....... 7 Woodside shale, distribution and character of..................... 20-30, 42, 46, 66 fossils of............................. 30 





